\title{
Anthropogenic radiative forcing time series from pre-industrial times until 2010
}

\author{
R. B. Skeie ${ }^{1}$, T. K. Berntsen ${ }^{1,2}$, G. Myhre ${ }^{1}$, K. Tanaka ${ }^{1,3}$, M. M. Kvalevåg ${ }^{1}$, and C. R. Hoyle ${ }^{3, *}$ \\ ${ }^{1}$ Center for International Climate and Environmental Research - Oslo (CICERO), Oslo, Norway \\ ${ }^{2}$ Department of Geosciences, University of Oslo, Oslo, Norway \\ ${ }^{3}$ Institute for Atmospheric and Climate Science, ETH Zurich, Zurich, Switzerland \\ *now at: Laboratory of Atmospheric Chemistry, Paul Scherrer Institut, Villigen, Switzerland
}

Received: 10 June 2011 - Published in Atmos. Chem. Phys. Discuss.: 10 August 2011

Revised: 11 November 2011 - Accepted: 14 November 2011 - Published: 29 November 2011

\begin{abstract}
In order to use knowledge of past climate change to improve our understanding of the sensitivity of the climate system, detailed knowledge about the time development of radiative forcing (RF) of the earth atmosphere system is crucial. In this study, time series of anthropogenic forcing of climate from pre-industrial times until 2010, for all well established forcing agents, are estimated. This includes presentation of RF histories of well mixed greenhouse gases, tropospheric ozone, direct- and indirect aerosol effects, surface albedo changes, stratospheric ozone and stratospheric water vapour. For long lived greenhouse gases, standard methods are used for calculating RF, based on global mean concentration changes. For short lived climate forcers, detailed chemical transport modelling and radiative transfer modelling using historical emission inventories is performed. For the direct aerosol effect, sulphate, black carbon, organic carbon, nitrate and secondary organic aerosols are considered. For aerosol indirect effects, time series of both the cloud lifetime effect and the cloud albedo effect are presented. Radiative forcing time series due to surface albedo changes are calculated based on prescribed changes in land use and radiative transfer modelling. For the stratospheric components, simple scaling methods are used. Long lived greenhouse gases (LLGHGs) are the most important radiative forcing agent with a RF of $2.83 \pm 0.28 \mathrm{~W} \mathrm{~m}^{-2}$ in year 2010 relative to 1750 . The two main aerosol components contributing to the direct aerosol effect are black carbon and sulphate, but their contributions are of opposite sign. The total direct aerosol effect
\end{abstract}

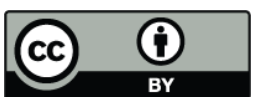

Correspondence to: R. B. Skeie (r.b.skeie@cicero.uio.no) was $-0.48 \pm 0.32 \mathrm{~W} \mathrm{~m}^{-2}$ in year 2010. Since pre-industrial times the positive RF (LLGHGs and tropospheric $\mathrm{O}_{3}$ ) has been offset mainly by the direct and indirect aerosol effects, especially in the second half of the 20th century, which possibly lead to a decrease in the total anthropogenic RF in the middle of the century. We find a total anthropogenic RF in year 2010 of $1.4 \mathrm{~W} \mathrm{~m}^{-2}$. However, the uncertainties in the negative RF from aerosols are large, especially for the cloud lifetime effect.

\section{Introduction}

Since the industrial revolution, anthropogenic activities have altered the concentrations of components in the atmosphere, some of which impact the radiative balance of the earth system. Long-lived greenhouse gases, primarily carbon dioxide $\left(\mathrm{CO}_{2}\right)$ but also methane $\left(\mathrm{CH}_{4}\right)$, nitrous oxide $\left(\mathrm{N}_{2} \mathrm{O}\right)$ and halocarbons are the most important anthropogenic climate forcing agents (Forster et al., 2007), but short lived components like tropospheric ozone and black carbon aerosols cause also a significant heating of the climate system. Sulphate, organic carbon and nitrate form short lived aerosols that scatter solar radiation and thus lead to a cooling of the climate system through the direct aerosol effect. In addition, the aerosols can alter the cloud properties, causing indirect aerosol effects (Twomey, 1977; Albrecht, 1989). Also, changes in stratospheric water vapour and ozone in the stratosphere as well as anthropogenic changes to the properties of the land surface give a radiative forcing on the climate system (Forster et al., 2007).

Published by Copernicus Publications on behalf of the European Geosciences Union. 
In order to understand recent climate change, knowing the radiative forcing time series for climate forcers is important. Not only radiative forcing at the present time, relative to the pre-industrial era, as is often presented in radiative forcing studies (e.g Gauss et al., 2006; Schulz et al., 2006), is of interest, but also how the radiative forcing has developed over time (Myhre et al., 2001; Takemura et al., 2006; Hansen et al., 2007). Also for future climate change, knowledge of what has happened in the past is important. Climate sensitivity, the equilibrium surface temperature change following a doubling of the $\mathrm{CO}_{2}$ concentration, is a highly uncertain but very important parameter for future climate change prediction (Knutti and Hegerl, 2008). To constrain the climate sensitivity, based on simple climate models and observed temperature change, knowledge of the historical development in the total radiative forcing is crucial (Tanaka et al., 2009).

In this study, we present time series of the radiative forcing, from pre-industrial times until 2010, for the main anthropogenic components which influence climate. The concentration increases of well mixed greenhouse gases since pre-industrial times are well known from ice core drilling (e.g. MacFarling Meure et al., 2006) and in situ observations, from which RF time series can be calculated. For short lived components, there is a lack of spatial and temporal coverage in observations. Based on surface radiation measurements, a decrease of solar radiation from the early 1960s up to the late 1980s was found (Ohmura and Lang, 1989), and at the end of the 20th century a surface solar brightening at numerous stations in Europe and the United States was observed (Wild et al., 2005, 2009), related to a decline in anthropogenic emissions of short lived aerosols and aerosol precursors. Historical emission inventories show that there has been a spatial shift in the distribution of emissions. For example, sulphur dioxide emissions peaked in Europe and North America in the 1970s, while emissions in Eastern Asia continuously increased over the 20th century (Smith et al., 2011). For carbonaceous aerosols emitted from fossil fuel and biofuel combustion, a similar pattern is found, with the industrialized countries having a large share of the emissions in the first part of the 20th century and the developing countries a larger share at the end of the century (Bond et al., 2007).

The main focus of this work is on the short lived components, tropospheric ozone and aerosols. The anthropogenic aerosols included are sulphate, primary organic carbon and black carbon of both fossil fuel and biomass burning origin, secondary organic aerosols and nitrate. Due to their short atmospheric lifetime, the changes in the geographical pattern of the emissions change the geographical distribution of the components. Since the RF depends significantly on location, and there is significant co-variance with clouds and humidity, detailed atmospheric chemistry and aerosol modelling are needed to calculate RF for the short lived species. We use a chemical transport model (CTM) to calculate the concentration changes of aerosols and tropospheric ozone due to anthropogenic activities and a radiative transfer model for calculating RF time series. The historical emission inventory of Lamarque et al. (2010) is used, which is also used in the historical CMIP5 (Coupled Model Intercomparison Project Phase 5) simulations for IPCC fifth assessment report.

We present radiative forcing time series due to anthropogenic activities from pre-industrial times until present. Compared to previous works (Myhre et al., 2001; Takemura et al., 2006; Hansen et al., 2007) the RF time series of short lived climate components are based on revised emission inventories (Lamarque et al., 2010), detailed modelling by a CTM and radiative transfer modelling, and the time period considered is extended to 2010. The paper is organized as follows. In Sect. 2 the methods used for calculating the RF trends are described and in Sect. 3 the results and RF time series are presented. At the end of Sect. 3 the simulated changes in radiation in different regions of the world are compared with the observed global radiation compiled in the Global Energy Balance Archive (GEBA). In Sect. 4 the results are discussed and the summary and conclusions are given in Sect. 5.

\section{Methods}

In this section the methods used for calculating the radiative forcing time series are described.

\subsection{Long lived greenhouse gases}

The radiative forcing time series for the long lived greenhouse gases (LLGHG) is calculated based on simplified expressions from Myhre et al. (1998) and IPCC 2001 (Ramaswamy et al., 2001), using historical concentrations based on observational data as input. For halocarbons we use the updated radiative efficiencies given in Table 2.14 in IPCC 2007 (Forster et al., 2007). The time series of the LLGHG concentrations from 1850 until 2010 are downloaded from http://data.giss.nasa.gov/modelforce/ghgases/ (Hansen et al., 1998; Hansen and Sato, 2004). These concentration series (GISS data) are based on ice core data and in situ measurements. The concentration time series are extended backwards from 1850 to 1750 using ice core data from Etheridge et al. (1996) for $\mathrm{CO}_{2}$ and from Etheridge et al. (1998) for $\mathrm{CH}_{4}$ (the same ice core data as used in the GISS data), which were reproduced by a more recent study from MacFarling Meure et al. (2006). For $\mathrm{N}_{2} \mathrm{O}$, MacFarling Meure et al. (2006) found lower pre-industrial concentrations than what is specified in the GISS data (Machida et al., 1995). The two ice cores have similar $\mathrm{N}_{2} \mathrm{O}$ concentrations back to 1900. We have used the MacFarling Meure et al. (2006) data from 1900 and back to 1750 .

\subsection{Tropospheric ozone and aerosols}

The OsloCTM2 model was used for calculating the concentration changes of tropospheric ozone $\left(\mathrm{O}_{3}\right)$ and aerosols. 
Table 1. Emissions used in this study. For each year and component the annual total anthropogenic and biomass burning emissions are listed. The natural emissions are presented in the bottom line. The year with maximum emissions are marked with a star $\left(^{*}\right)$.

\begin{tabular}{|c|c|c|c|c|c|c|c|c|c|c|c|c|c|}
\hline & \multirow[b]{2}{*}{$\begin{array}{c}\mathrm{CO} \\
(\mathrm{Tg})\end{array}$} & \multirow[b]{2}{*}{$\begin{array}{c}\text { NMHC } \\
(\mathrm{Tg})\end{array}$} & \multirow[b]{2}{*}{$\begin{array}{c}\mathrm{NO}_{\mathrm{x}} \\
(\mathrm{Tg} \mathrm{N})\end{array}$} & \multirow[b]{2}{*}{$\begin{array}{c}\mathrm{NH}_{3} \\
(\mathrm{TgN})\end{array}$} & \multirow[b]{2}{*}{$\begin{array}{c}\mathrm{SO}_{2}+\mathrm{SO}_{4} \\
(\mathrm{Tg} \mathrm{S})\end{array}$} & \multirow[b]{2}{*}{$\begin{array}{c}\text { DMS } \\
(\mathrm{Tg})\end{array}$} & \multirow[b]{2}{*}{$\begin{array}{l}\text { FFBF BC } \\
\quad(\mathrm{Tg})\end{array}$} & \multirow[b]{2}{*}{$\begin{array}{c}\mathrm{BC} \mathrm{BB} \\
(\mathrm{Tg})\end{array}$} & \multirow[b]{2}{*}{$\begin{array}{c}\text { FFBF OC } \\
\quad(\mathrm{Tg})\end{array}$} & \multirow[b]{2}{*}{$\begin{array}{c}\mathrm{OC} \mathrm{BB} \\
(\mathrm{Tg})\end{array}$} & \multirow[b]{2}{*}{$\begin{array}{c}\text { Isoprene } \\
\text { (Tg) }\end{array}$} & \multicolumn{2}{|c|}{ SOA precursors: } \\
\hline & & & & & & & & & & & & $\begin{array}{l}\text { Bio. VOC } \\
\text { (Tg C) }\end{array}$ & $\begin{array}{c}\text { Ant. VOC } \\
\quad(\mathrm{Tg})\end{array}$ \\
\hline 1750 & 174 & 10 & 2 & 4 & 1 & - & 0.2 & 1.0 & 1 & 9 & - & - & 2 \\
\hline 1850 & 386 & 22 & 5 & 10 & 2 & - & 1.0 & 2.1 & 4 & 18 & - & - & 4 \\
\hline 1900 & 434 & 25 & 8 & 12 & 12 & - & 2.3 & 2.1 & 6 & 18 & - & - & 6 \\
\hline 1910 & 448 & 25 & 9 & 13 & 18 & - & 2.7 & 2.0 & 7 & 18 & - & - & 6 \\
\hline 1920 & 431 & 25 & 9 & 13 & 19 & - & 2.9 & 1.9 & 7 & 16 & - & - & 6 \\
\hline 1930 & 459 & 26 & 10 & 14 & 23 & - & 2.8 & 1.9 & 8 & 15 & - & - & 7 \\
\hline 1940 & 474 & 28 & 11 & 14 & 27 & - & 2.8 & 1.9 & 8 & 15 & - & - & 7 \\
\hline 1950 & 539 & 33 & 14 & 18 & 31 & - & 2.9 & 1.8 & 8 & 14 & - & - & 9 \\
\hline 1960 & 664 & 51 & 18 & 21 & 47 & - & 3.2 & 1.9 & 9 & 15 & - & - & 15 \\
\hline 1970 & 809 & 69 & 25 & 27 & 63 & - & 3.3 & 2.2 & 10 & 17 & - & - & 22 \\
\hline 1980 & 968 & 84 & 32 & 36 & $65^{*}$ & - & 4.5 & 2.4 & 10 & 20 & - & - & 28 \\
\hline 1990 & 1099 & $93^{*}$ & 37 & $44^{*}$ & 64 & - & 4.8 & $2.9^{*}$ & 11 & $24^{*}$ & - & - & 31 \\
\hline 2000 & 1069 & 86 & $37^{*}$ & 40 & 54 & - & 5.0 & 2.8 & 12 & 24 & - & - & 29 \\
\hline 2010 & $1118^{*}$ & 90 & 37 & 44 & 56 & - & $5.6^{*}$ & 2.8 & $13^{*}$ & 24 & - & - & $31^{*}$ \\
\hline Nat. emis. & 180 & 39 & 13 & 14 & 13 & 57 & - & - & - & - & 220 & 175 & - \\
\hline
\end{tabular}

Time slice simulations are done for 1850,1900 and thereafter every 10th year until 2010. Each time slice simulation is one year long and meteorological data for the year 2006 are used. Each simulation is initialized by the same pre-industrial model climatology and a three year spin up is used. Anthropogenic and biomass burning historical emission data are from Lamarque et al. (2010). For year 2010 anthropogenic emissions from the Representative Concentration Pathways scenario RCP4.5 (Thomson et al., 2011) are used, which are consistent with the historical emission data (Lamarque et al., 2010). For biomass burning we have used the year 2000 emissions for 2010. In addition, a simulation with pre-industrial emissions has been performed. We use the 1850s emissions from Lamarque et al. (2010) as a basis, switching off all sectors except agriculture, agriculture- and waste burning and the domestic sector, which are reduced to $20 \%$ of the 1850 emissions. This is a larger reduction in emission than scaling with $\sim 60 \%$ based on global population growth estimated by Goldewijk (2005). However, a simple scaling factor related to global population does not capture growth in emissions per capita between 1750 and 1850 due to technology improvements, migration and landuse change and we have therefore used a lower factor. For the biomass burning, the emissions are assumed to be half of the 1850 s emissions, which is consistent with the total preindustrial emission data from Dentener (2006b). The total annual emissions are presented in Table 1.

The natural emissions (Table 1) are assumed to be constant throughout the simulation period to separate the anthropogenic contribution. The lightning emissions are based on Price et al. (1997) scaled to $5 \mathrm{Tg} \mathrm{N} \mathrm{yr}^{-1}$ and distributed over the year by convection activity data. The natural emissions of $\mathrm{CO}, \mathrm{NO}_{\mathrm{x}}$, and hydrocarbons from vegetation, ocean and soil are from the POET emission inventories (Granier et al., 2005). The isoprene and biogenic volatile organic compounds (VOCs) important in SOA formation are as used in Hoyle et al. (2009). The natural emissions of sulphur species are as described in Berglen et al. (2004) except that we use the parameterizations of the DMS flux from Nightingale et al. (2000) and emission from continuous degassing volcanoes from Dentener et al. (2006b).

OsloCTM2 is an off-line atmospheric chemistry transport model, driven by meteorological data generated by the Integrated Forecast System (IFS) model at the European Centre for Medium-Range Weather Forecasts (ECMWF). The resolution of the model used in this study is T42, (approximately $2.8^{\circ} \times 2.8^{\circ}$ ) with 60 vertical layers ranging from the surface up to $0.1 \mathrm{hPa}$. In this study we include the tropospheric chemistry scheme (Berntsen and Isaksen, 1997; Dalsøren et al., 2010), as well as modules for sulphate, nitrate, black carbon, primary organic carbon, secondary organic aerosols, mineral dust and sea salt.

The sulphur chemistry scheme is coupled with the oxidant chemistry (Berglen et al., 2004). For black carbon (BC) and primary organic carbon (OC), a simple bulk scheme is used (Berntsen et al., 2006; Rypdal et al., 2009; Skeie et al., 2011), with the aging time dependent on season and latitude (Skeie et al., 2011). We treat OC and BC from fossil fuel and biofuel (FFBF) and biomass burning (BB) separately. Time series of RF for FFBF BC are presented in Skeie et al. (2011), and therefore we do not focus on FFBF BC in this study. We also include a scheme for secondary organic aerosols (SOA), where secondary organic aerosols are formed by condensation of the oxidation products of hydrocarbons (Hoyle et al., 2007). We allow the semi-volatile species to partition to ammonium sulphate aerosols as well as existing organic aerosols. For nitrate, a thermodynamical model for treatment of gas/aerosol partitioning of semi-volatile inorganic 
aerosols is used based on the EQUSAM model (Metzger et al., 2002). Chemical equilibrium between inorganic compounds is simulated, including sea salt. The nitrate module used is described in Myhre et al. (2006) and the sea salt module in Grini et al. (2002). Nitrate is separated in a coarse and a fine mode, for separating the radiative properties of the nitrate aerosols. In the OsloCTM2, the mineral dust emissions are driven by wind (Grini et al., 2005), and we do not include anthropogenic changes to the soil erodibility, so no changes in the dust emissions are assumed for the historical time period in this study. In the stratosphere monthly model climatological values of ozone and nitrogen species are used, except in the 3 lowermost layers in the stratosphere (approximately $2.5 \mathrm{~km}$ ) where the tropospheric chemistry scheme is applied to account for photochemical $\mathrm{O}_{3}$ production in the lower stratosphere due to emissions of $\mathrm{NO}_{\mathrm{x}}, \mathrm{CO}$ and VOCs.

The chemistry module has been evaluated in Søvde et al. $(2008 ; 2011)$, references above, as well as in multi model studies (Dentener et al., 2006a; Gauss et al., 2006; Shindell et al., 2006b; Stevenson et al., 2006; Fiore et al., 2009). Remark that changes in the model have been included since these multi model studies were preformed where OsloCTM2 overestimated $\mathrm{O}_{3}$ in the tropics. The model has been involved in the AeroCom aerosol multi model comparison project (Kinne et al., 2006; Schulz et al., 2006; Textor et al., 2006), and the aerosol module has been validated against in situ measurements and remote sensing data (Myhre et al., 2009). Myhre et al. (2009) found that the mean pattern of aerosol optical depth from the model is broadly similar to the AERONET network of ground-based sun photometers and satellite retrievals.

The optical properties for the direct aerosol effect simulations are described in Myhre et al. (2007a). Radiative forcing is calculated for the concentration changes by adopting the DISORT radiative transfer model (Stamnes et al., 1988; Myhre et al., 2007a) in offline calculations. The radiative transfer simulations are performed with 8 streams. The meteorological data including the cloud data are the same as used in OsloCTM2. For tropospheric $\mathrm{O}_{3}$ a broadband code for long wave radiation and the DISORT code for short wave radiation is used (Myhre et al., 2000).

The cloud albedo effect has been simulated using the approach from Quaas et al. (2006). They established a relationship between the concentration of cloud droplets and aerosols based on Moderate Resolution Imaging Spectroradiometer (MODIS) data. All hydrophilic aerosols, including natural aerosols such as sub-micron size sea salt, sulphate, nitrate, primary and secondary organic aerosols are included in this approach. The changes in the concentration of cloud droplets alter the cloud effective radius and thus the optical properties of the clouds. The radiative forcing is calculated using the same radiative transfer model as described above. This approach for the cloud albedo effect is restricted to water clouds.
For the cloud lifetime effect, the RF time series is created in a simple way by scaling the best estimate of the current RF given in the review by Isaksen et al. (2009) who established, based on published estimates using models and satellite data, a best estimate and an uncertainty range for the cloud lifetime effect in 2007 relative to pre-industrial times. The cloud lifetime effect is scaled back in time using the RF time series for the cloud albedo effect. Rotstayn and Penner (2001) find, in a GCM study, that the magnitude and spatial distribution of the cloud albedo effect and cloud lifetime effect were similar. This indicates that both processes are governed by the change in aerosol concentrations without any strong non-linear effects and thus that a simple linear scaling is a reasonable approach.

\subsection{Stratospheric forcing agents}

Due to the increase in ozone depleting components, stratospheric $\mathrm{O}_{3}$ has decreased over the latter part of 20th century (Douglass et al., 2011). Time slice simulations with OsloCTM2 including stratospheric chemistry were not performed. Søvde et al. (2011) performed simulations of stratospheric $\mathrm{O}_{3}$ in the year 2000, relative to 1850 , using OsloCTM2 including stratospheric chemistry. The resulting RF estimates were separated for source and source regions. Estimates were separated for changes in ozone due to tropospheric $\mathrm{O}_{3}$ precursors and changes in ozone due to chlorine and bromine components. The estimates were also separated for ozone changes occurring in the troposphere and for changes occurring in the stratosphere. The estimated $\mathrm{RF}$ due to chlorine and bromine, was $-0.20 \mathrm{~W} \mathrm{~m}^{-2}$ in the stratosphere and $-0.06 \mathrm{~W} \mathrm{~m}^{-2}$ in the troposphere. We scale this total $\mathrm{RF}$ from chlorine and bromine $\left(-0.26 \mathrm{~W} \mathrm{~m}^{-2}\right)$ with a time series of equivalent effective stratospheric chlorine (EESC) (Daniel and Velders, 2007) which we will call stratospheric $\mathrm{O}_{3} \mathrm{RF}$. So in this study we separate the RF of ozone due to emissions of ozone depleting components, labelled stratospheric $\mathrm{O}_{3} \mathrm{RF}$, and RF due to emissions of ozone precursors, labelled tropospheric $\mathrm{O}_{3} \mathrm{RF}$, even if the changes are not restricted to the troposphere or stratosphere. The scaling of EESC with a present day RF is a simple approach to construct the RF time series assuming linearity of stratospheric $\mathrm{O}_{3} \mathrm{RF}$. Forster and Shine (1997) investigated the linearity of stratospheric $\mathrm{O}_{3}$ forcing, and found the RF was quite linear, within $7 \%$, with the magnitude of the ozone depletion.

The increased amount of $\mathrm{CH}_{4}$ in the stratosphere will increase stratospheric water vapour $\left(\mathrm{H}_{2} \mathrm{O}\right)$ when it is oxidised. Due to the low amount of water vapour in the stratosphere, and water vapour being a strong greenhouse gas, this will give a RF. The RF of stratospheric water vapour for 2005 relative to pre-industrial times given in the IPCC 2007 was $0.07 \pm 0.05 \mathrm{~W} \mathrm{~m}^{-2}, 15 \%$ of the methane forcing (Forster et al., 2007). To construct a RF time series of $\mathrm{H}_{2} \mathrm{O}$ in the stratosphere we make a simple assumption assuming a linear relationship between the $\mathrm{CH}_{4} \mathrm{RF}$ and stratospheric $\mathrm{H}_{2} \mathrm{O}$ 

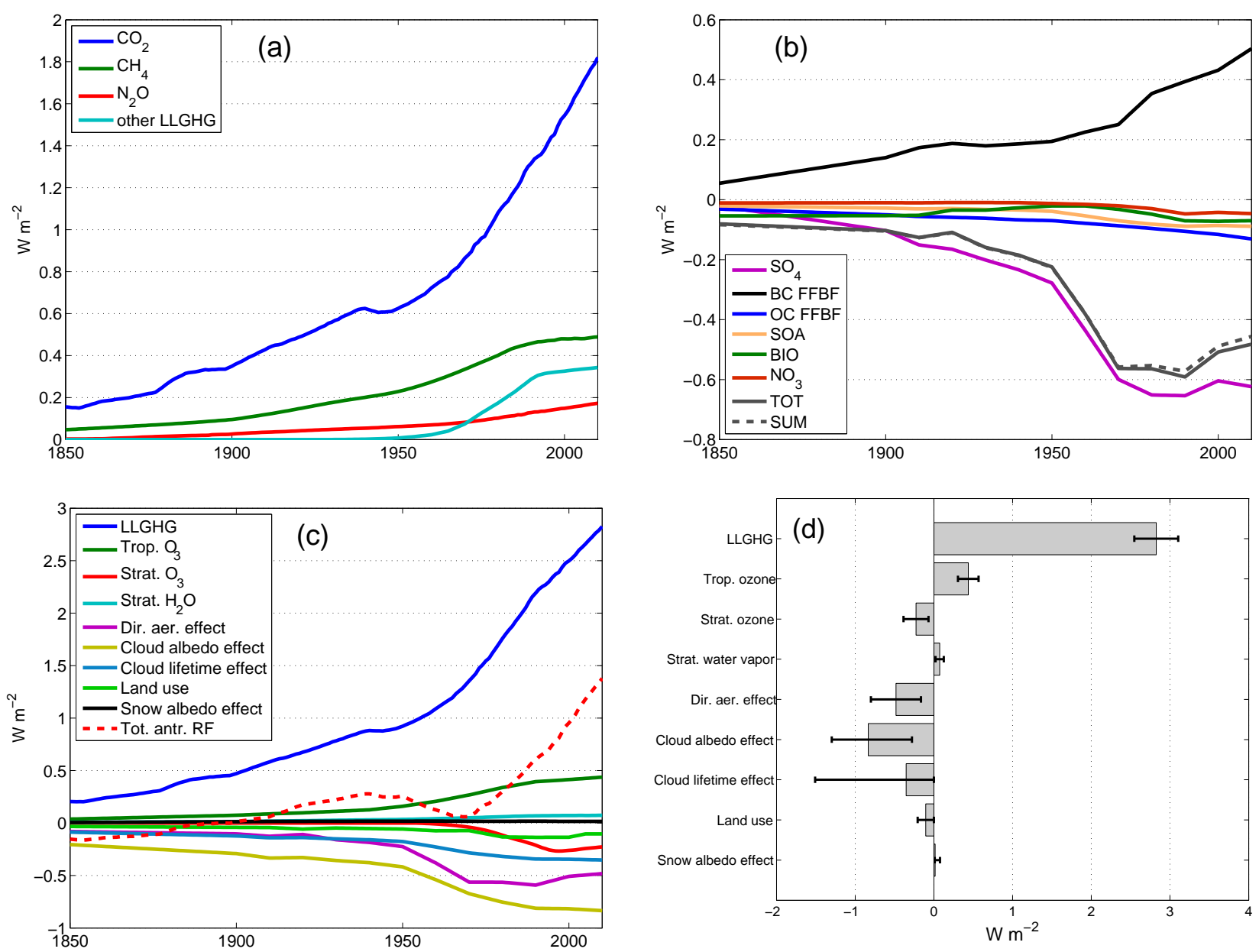

Fig. 1. Time series of radiative forcing from 1850 until 2010 for the LLGHGs (a), the direct aerosol effect (b), all anthropogenic forcing mechanisms (c) and RF in 2010 for all components (d). The error bars represent the $90 \%$ confidence interval.

RF. For stratospheric $\mathrm{H}_{2} \mathrm{O}$ RF due to $\mathrm{CH}_{4}$ oxidation Myhre et al. (2007b) made explicit calculations for 1950, 1979 and 2000 and the results were relatively linear with $\mathrm{CH}_{4}$ forcing. Remark that the time series presented here do not include dynamical causes for stratospheric $\mathrm{H}_{2} \mathrm{O}$, only forcing due to $\mathrm{CH}_{4}$ oxidation. To construct a $\mathrm{RF}$ time series of $\mathrm{H}_{2} \mathrm{O}$ in the stratosphere, we therefore scale the $\mathrm{CH}_{4} \mathrm{RF}$ time series with $15 \%$.

\subsection{Surface albedo changes}

The radiative forcing due to land use change is associated with the change in surface albedo due to deforestation for agricultural purposes. We use global data sets of cropland from 1750-2005 (from the updated dataset at www.geog. mcgill.ca/landuse/pub/Data/Histlanduse/ on the basis of Ramankutty and Foley (1999)) to prescribe changes in cropland during the industrial era. Surface albedo values are provided for 16 vegetation types (Loveland et al., 2000). We have adopted snow free surface albedo values in the visible and near infrared, calculated using the MODIS albedo product MOD43B3 (Zhou et al., 2003; Gao et al., 2005). Land use change also influences the hydrological cycle by altering i.e. runoff, evapotranspiration and precipitation (Kvalevag et al., 2010). These climate effects are considered as climate feedback mechanisms and are not included in this study.

Snow albedo values are calculated using the method in Betts (2000) which includes snow cover, snow depth and a maximum snow albedo values for each vegetation type. The maximum snow albedo values are latitude-average snow covered surface albedo retrieved by MODIS (Gao et al., 2005). We also consider the zenith angle dependent surface albedo for snow free conditions using the approach from Hou et al. (2002) where the zenith angle dependency is either strong or weak for different vegetation types, and typically strong for cropland. For snow covered vegetation we use the zenith angle dependency method introduced by Briegleb (1992) which uses a constant surface albedo for zenith angles below 60 degrees but varies for zenith angles above 60 degrees. 
The atmospheric radiative transfer model used to study land use change is the same as the one used for RF calculations of ozone and aerosols.

The RF time series of the snow albedo effect due to black carbon deposited on snow are taken from Skeie et al. (2011).

\section{Results}

In this section we present radiative forcing time series from 1750 to 2010 . Unless otherwise stated all RF values presented are relative to year 1750. The long-lived greenhouse gases are first presented and then the tropospheric $\mathrm{O}_{3}$ results, before the stratospheric components $\left(\mathrm{O}_{3}\right.$ and $\left.\mathrm{H}_{2} \mathrm{O}\right)$. Then we concentrate on each of the aerosol components, sulphate $\left(\mathrm{SO}_{4}\right)$, organic aerosols $(\mathrm{OC}+\mathrm{SOA}), \mathrm{BC}$, biomass burning aerosols and nitrate, before presenting the total direct aerosol effect and the indirect aerosol effects. Thereafter, radiative forcing caused by surface albedo changes is presented. Finally, the model results are compared with surface radiation observations from the GEBA database. The time series for each forcing component are plotted in Fig. 1 together with RF estimate for 2010 with an error bar indicating $90 \%$ confidence interval (Fig. 1d).

\subsection{Long-lived greenhouse gases}

The calculated radiative forcing time series of $\mathrm{CO}_{2}, \mathrm{CH}_{4}$, $\mathrm{N}_{2} \mathrm{O}$ and other LLGHGs (CFCs, HCFCs, HFCs, PFCs and $\mathrm{SF}_{6}$ ) are presented in Fig. 1a. The RF of $\mathrm{CO}_{2}$ has increased almost continuously over the whole time period except for one period around 1940-1950 the reason of which is still under debate (Trudinger et al., 2002; MacFarling Meure et al., 2006; Rafelski et al., 2009). The RF of $\mathrm{CO}_{2}$ has increased rapidly since 1950 , from $0.62 \mathrm{~W} \mathrm{~m}^{-2}$ to $1.82 \mathrm{~W} \mathrm{~m}^{-2}$ in 2010 . Over the last five years, the $\mathrm{CO}_{2} \mathrm{RF}$ increased by $8.1 \%$. The $\mathrm{RF}$ of $\mathrm{CH}_{4}$ has flattened out over the last decades, with a value of $0.49 \mathrm{~W} \mathrm{~m}^{-2}$ in 2010 . However, a renewed increase in the $\mathrm{CH}_{4}$ concentrations in the last couple of years has been observed (Rigby et al., 2008). The forcing of $\mathrm{N}_{2} \mathrm{O}$ increased gradually since the beginning of 20th century, reaching $0.17 \mathrm{~W} \mathrm{~m}^{-2}$ in 2010 . Over the last decades, the level of RF of other LLGHGs flattened out, due to the reduction of the emissions of components covered by the Montreal Protocol (Montzka et al., 2011b). In 2010 the RF of other LLGHG is estimated to be $0.34 \mathrm{~W} \mathrm{~m}^{-2}$.

The total RF of LLGHGs is plotted in Fig. 1c. The total RF of LLGHGs in 2010 is $2.83 \mathrm{~W} \mathrm{~m}^{-2}$ (Fig. 1d) of which $\mathrm{CO}_{2}$ contributed $64 \%$. The RF of LLGHGs has increased by $0.17 \mathrm{~W} \mathrm{~m}^{-2}$ over the last $5 \mathrm{yr}$. Compared to Forster et al. (2007) the RF estimate of LLGHGs in 2005 is $0.03 \mathrm{~W} \mathrm{~m}^{-2}(1.1 \%)$ larger in this study, mainly due to $1 \mathrm{ppm}$ smaller pre-industrial concentrations of $\mathrm{CO}_{2}$ in this study. The error bar added for this component has the same relative uncertainty of $10 \%$ as in Forster et al. (2007), which includes the uncertainties in the RF calculations from concentration changes and uncertainties in the measured concentrations levels, especially the pre-industrial concentrations. The uncertainty in the measured $\mathrm{CO}_{2}$ concentration today is less than $0.15 \mathrm{ppm}$ and for pre-industrial concentrations the uncertainty is $1.2 \mathrm{ppm}$ (Forster et al., 2007). The preindustrial values used in our calculations of radiative forcing are $277 \mathrm{ppm}$ for $\mathrm{CO}_{2}, 710 \mathrm{ppb}$ for $\mathrm{CH}_{4}$ and $271 \mathrm{ppb}$ for $\mathrm{N}_{2} \mathrm{O}$, while most of the halocarbons are of anthropogenic origin and have therefore no pre-industrial concentration. The RF time series are based on observed concentration changes, and might therefore include geo-chemical feedbacks.

\subsection{Tropospheric ozone and oxidation capacity}

Ozone is produced in the troposphere by oxidation of carbon monoxide $(\mathrm{CO})$, methane $\left(\mathrm{CH}_{4}\right)$ and non methane hydrocarbons (NMHC) in presence of nitrogen oxides $\left(\mathrm{NO}_{\mathrm{x}}=\mathrm{NO}\right.$ $+\mathrm{NO}_{2}$ ) and sunlight. The anthropogenic emissions of these ozone precursors have changed over the industrialized period (Table 1), and modelling studies show an increase in tropospheric $\mathrm{O}_{3}$ and thus a positive RF (e.g. Berntsen et al., 2000; Lamarque et al., 2005; Shindell et al., 2006a). Observational studies have also shown increase in tropospheric ozone (Logan, 1994; Staehelin et al., 1994; Logan et al., 1999; Oltmans et al., 2006; Derwent et al., 2007).

\subsubsection{Tropospheric ozone}

The time series of the calculated $\mathrm{RF}$ from $\mathrm{O}_{3}$ is presented in Fig. 1c, showing a steep increase in the decades following the $1950 \mathrm{~s}$, and flattening out over the last decades. This results in a RF in 2010 of $0.44 \mathrm{~W} \mathrm{~m}^{-2}$ (Fig. 1d), corresponding to $24 \%$ of the $\mathrm{CO}_{2}$ forcing.

In Table 2, the global mean tropospheric burden change since 1750 is presented. The largest increase is found between 1950 and 1980 with a $42 \%$ of the total increase in $\mathrm{O}_{3}$ burden. The total increase is $9.9 \mathrm{DU}$ in $2000 \mathrm{com}$ pared to 1850 , in line with the range of 7.9 DU to $13.8 \mathrm{DU}$ from the multi model study by Gauss et al. (2006) and the 9 DU increase between 1850 and 2000 found by Lamarque et al. (2010), who used the same emission inventories as in this study. The total increase between 1750 and 2010 in this study is $11.4 \mathrm{DU}$.

Most of the burden change occurred after 1950 (Table 2), and in Fig. 2a and $b$ the absolute and relative differences in the annual zonal mean $\mathrm{O}_{3}$ between 1950 and 2000 are shown. The largest increase is found in the Northern Hemisphere $(\mathrm{NH})$, where the ozone precursor changes are largest (Fig. 2c-d), and the largest relative increase in ozone is found at the surface in the $\mathrm{NH}$ (Fig. 2b). For $\mathrm{NO}_{\mathrm{x}}$ (lifetime $\sim$ day) the increase is located closer to the surface (Fig. 2c) than for CO (lifetime $\sim$ month) which has a more homogeneous change in the $\mathrm{NH}$, from the surface and through the troposphere (Fig. 2d). The $\mathrm{NO}_{\mathrm{x}}$ concentration has increased at 
Table 2. The increase in modelled global mean burden for each component since pre-industrial times.

\begin{tabular}{|c|c|c|c|c|c|c|c|c|c|}
\hline & $\begin{array}{c}\text { Trop. } \mathrm{O}_{3} \\
\text { (DU) }\end{array}$ & $\begin{array}{c}\mathrm{SO}_{4} \\
(\mathrm{Tg} \mathrm{S})\end{array}$ & $\begin{array}{l}\text { FFBF BC } \\
\quad(\mathrm{Gg})\end{array}$ & $\begin{array}{l}\text { FFBF OC } \\
\quad(\mathrm{Gg})\end{array}$ & $\begin{array}{l}\text { SOA } \\
(\mathrm{Gg})\end{array}$ & $\begin{array}{c}\text { BC BB } \\
(\mathrm{Gg})\end{array}$ & $\begin{array}{c}\text { OC BB } \\
(\mathrm{Gg})\end{array}$ & $\begin{array}{c}\mathrm{NO}_{3} \mathrm{FIN} \\
(\mathrm{Gg} \mathrm{N})\end{array}$ & $\begin{array}{c}\mathrm{NH}_{4} \mathrm{FIN} \\
(\mathrm{Gg} \mathrm{N})\end{array}$ \\
\hline 1850 & 1.0 & 0.01 & 14 & 52 & 50 & 25 & 203 & 5.3 & 39 \\
\hline 1900 & 1.9 & 0.07 & 36 & 85 & 68 & 26 & 205 & 5.0 & 65 \\
\hline 1910 & 2.3 & 0.11 & 44 & 96 & 75 & 24 & 195 & 5.1 & 72 \\
\hline 1920 & 2.5 & 0.12 & 47 & 100 & 72 & 20 & 149 & 4.7 & 74 \\
\hline 1930 & 2.9 & 0.15 & 45 & 105 & 80 & 21 & 148 & 4.8 & 86 \\
\hline 1940 & 3.2 & 0.17 & 46 & 115 & 85 & 20 & 137 & 5.0 & 90 \\
\hline 1950 & 4.1 & 0.21 & 48 & 118 & 97 & 21 & 130 & 6.6 & 117 \\
\hline 1960 & 5.4 & 0.33 & 55 & 135 & 140 & 22 & 151 & 8.5 & 159 \\
\hline 1970 & 7.0 & 0.46 & 59 & 147 & 185 & 29 & 208 & 11 & 214 \\
\hline 1980 & 8.9 & 0.50 & 83 & 161 & 217 & 35 & 260 & 17 & 282 \\
\hline 1990 & 10.3 & 0.50 & 90 & 178 & 238 & 46 & 358 & 28 & 341 \\
\hline 2000 & 10.9 & 0.46 & 98 & 195 & 230 & 41 & 338 & 24 & 322 \\
\hline 2010 & 11.4 & 0.48 & 113 & 223 & 240 & 42 & 339 & 26 & 353 \\
\hline
\end{tabular}
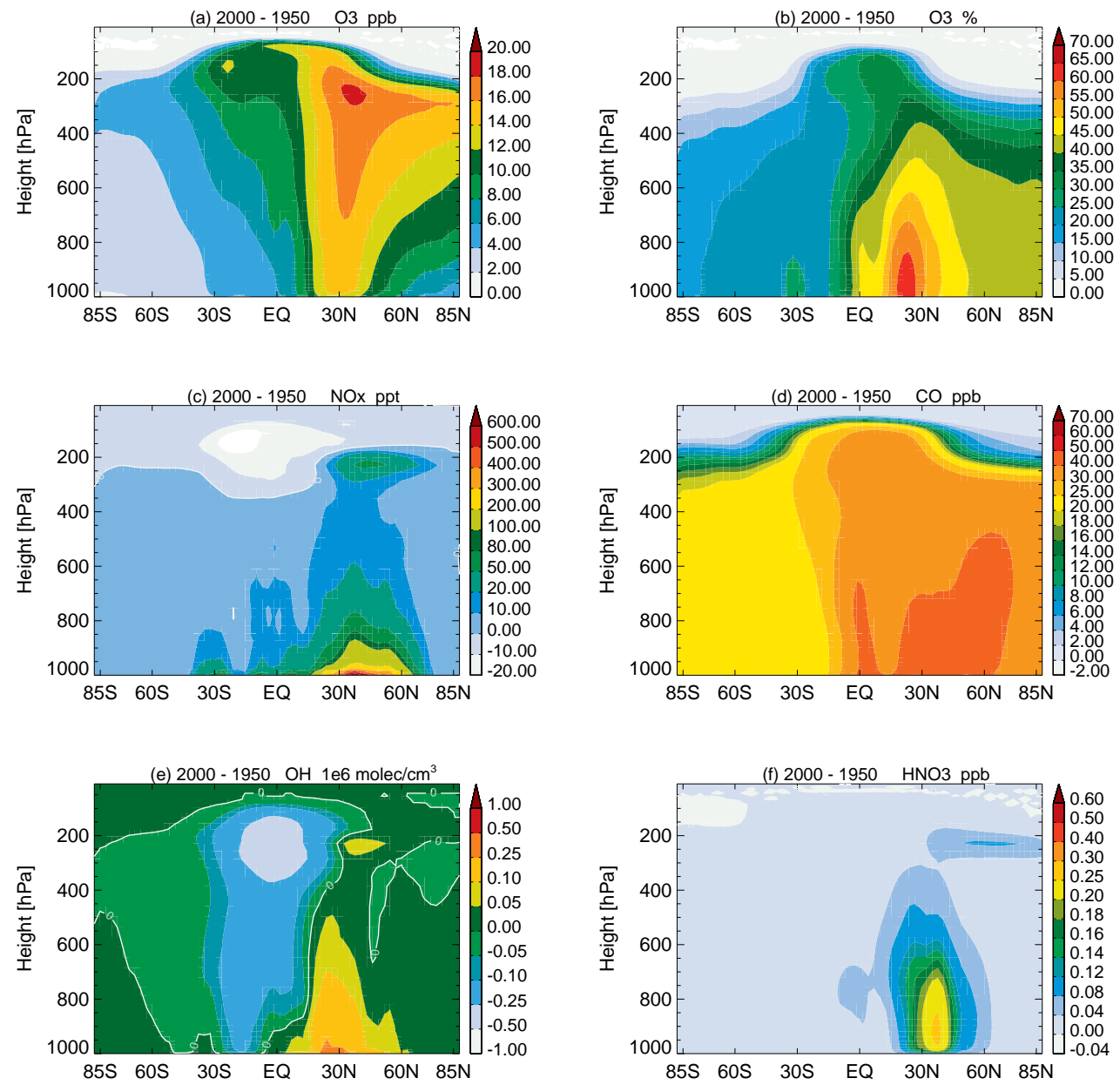

Fig. 2. The 2000-1950 difference in annual mean zonal concentration for $\mathrm{O}_{3}$ absolute (a), $\mathrm{O}_{3}$ relative $(\%)(\mathbf{b}), \mathrm{NO}_{\mathrm{x}}(\mathbf{c}), \mathrm{CO}(\mathbf{d}), \mathrm{OH}(\mathbf{e})$ and $\mathrm{HNO}_{3}$ (f). 

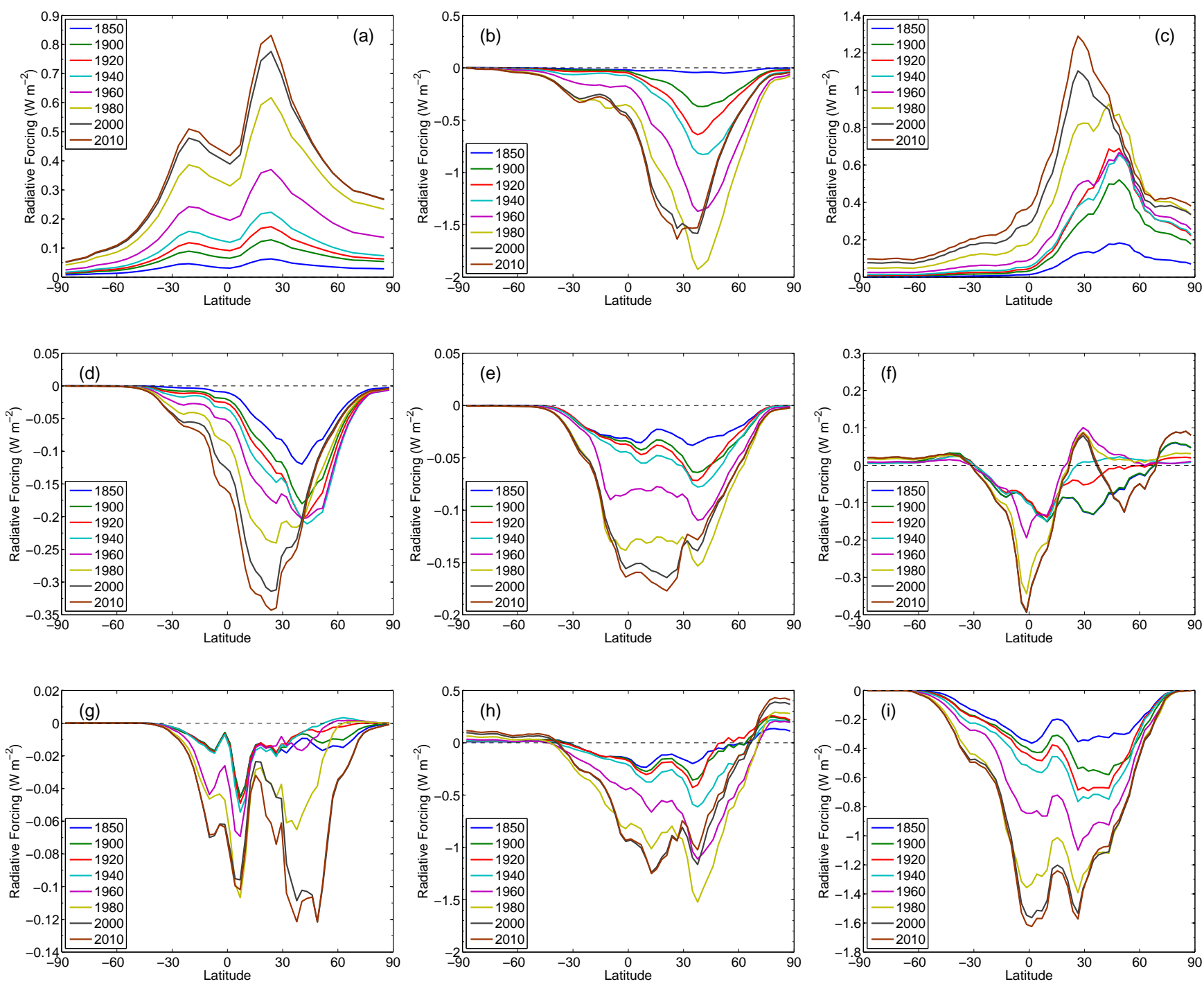

Fig. 3. Zonal mean RF for selected years for tropospheric ozone (a), direct aerosol effect of sulphate (b), FFBF BC (c), FFBF OC (d), SOA (e), BB aerosols (f), nitrate (g), total direct aerosol effect (h) and the cloud albedo effect (i).

high altitude at mid-latitudes in the $\mathrm{NH}$ due to convective transport from the boundary layer and emissions from aviation. At high altitudes, above the equator, there is a decrease in the $\mathrm{NO}_{\mathrm{x}}$ concentrations. This is in the same region as $\mathrm{OH}$ decreased (Fig. 2e) due to increased loss through reaction with $\mathrm{CO}$ and $\mathrm{CH}_{4}$ leading to increased $\mathrm{HO}_{2}$ concentration. The decrease in $\mathrm{NO}_{\mathrm{x}}$ in this region is compensated by an increase in other forms of reactive nitrogen, mainly $\mathrm{HO}_{2} \mathrm{NO}_{2}$, with small contribution from PAN and less contribution from $\mathrm{HNO}_{3}$ (Fig. 2f).

Figure 3 shows the calculated zonal mean RF for selected years. Tropospheric $\mathrm{O}_{3} \mathrm{RF}$ has a similar distribution for each decade, with a maximum at $20^{\circ} \mathrm{N}$ and a secondary maximum at $20^{\circ} \mathrm{S}$ (Fig. 3a). The largest RF in the $\mathrm{NH}$ is found in the Middle East, and in the Southern Hemisphere (SH) the strongest RF is located downwind from biomass burning areas.

There are limited observations in space and time that can be used to validate the modelled trend of tropospheric $\mathrm{O}_{3}$. During the last decades, surface ozone has been measured at several sites around the world. Figure 4a compares the modelled and observed surface ozone from the Global Atmospheric Watch (GAW) network. The figure compares the decadal median of the observed annual mean and the annual mean from the time slice simulations. The comparison is shown for those stations reporting observations in all three decades. A good representation of ozone at remote stations for the last decades is found with a correlation coefficient of 0.7. In Fig. 4b, modelled and observed $\mathrm{CO}$ are plotted. For low observed values, which are located in remote areas 

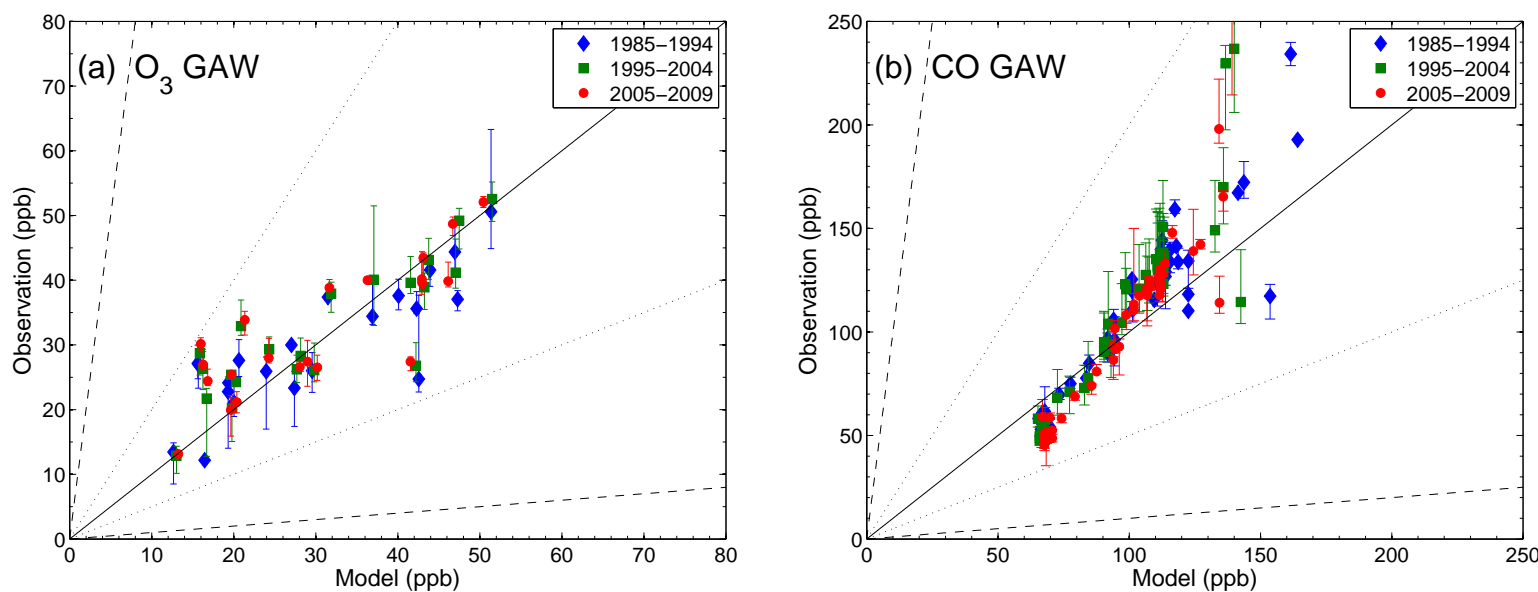

Fig. 4. The median of the observed annual means from the GAW network compared with the corresponding modelled annual mean for each decade. The comparisons are shown for $\mathrm{O}_{3}$ (a) and $\mathrm{CO}$ (b) for those stations operating in all decades. The solid line shows a one-to-one correspondence. The dotted lines show a factor of 2 difference and the dashed lines a factor 10 difference between the observations and model results. The error bars added to the observations denote the maximum and minimum of the annual means in the decade.

in the $\mathrm{SH}$, the model overestimates the $\mathrm{CO}$ concentrations. This might be due to an overestimation of the $\mathrm{CO}$ emissions from biomass burning which is the dominant source of $\mathrm{CO}$ in the $\mathrm{SH}$ or due to a too rapid transport of $\mathrm{CO}$ plumes away from the source regions in the model (Hoyle et al., 2011b). In NH extra tropics, Shindell et al. (2006b) found that models underestimate $\mathrm{CO}$ and attributed it to underestimations of $\mathrm{CO}$ emissions. Although the anthropogenic $\mathrm{CO}$ emissions are larger in this study (Lamarque et al., 2010) than in Shindell et al. (2006b) we underestimate the $\mathrm{CO}$ in the $\mathrm{NH}$ where $\mathrm{CO}$ concentrations are higher (Fig. 4b) than in $\mathrm{SH}$.

Radiative forcing from ozone is more sensitive to changes in ozone in the free troposphere than to changes close to the surface (Forster and Shine, 1997). For the current atmosphere, Fig. 5 compares the modelled monthly mean ozone for the year 2000 simulation at three pressure levels $750 \mathrm{hPa}$, $500 \mathrm{hPa}$ and $250 \mathrm{hPa}$, with ozone sonde observations in the time period 1980 to 2002 (Logan, 1999; Thompson et al., 2003a; Thompson et al., 2003b). In the SH, the model underestimates the ozone by about $10-15 \mathrm{ppb}$, except in the upper tropical troposphere. The model tends to overestimate $\mathrm{CO}$ in this region, as stated above. Large parts of the free troposphere in the $\mathrm{SH}$ are in a low $\mathrm{NO}_{\mathrm{x}}$ regime, where $\mathrm{CO}$ oxidation leads to ozone loss, and an overestimation of $\mathrm{CO}$ could hence give an underestimation of $\mathrm{O}_{3}$. The seasonal cycle of ozone is well captured in the southernmost latitude band. Between $30^{\circ} \mathrm{S}$ and equator, ozone peaks about a month too early (in August instead of September/October in the observations). The reason for this is not clear, but this is a region influenced by biomass burning, and the biomass burning emissions used in this study represent a decadal mean, which can influence the comparison between model and observations. The amplitude of the seasonal cycle is underestimated at $500 \mathrm{hPa} 30-90^{\circ} \mathrm{N}$, which is also found in the multi model study by Stevenson et al. (2006). They indicated lack of seasonal cycle in the anthropogenic emissions, as is the case for this study as well, and deficiencies in the stratospheric influx as reasons for the underestimation of the seasonal cycle in this latitude band. Apart for those regions mentioned above, the agreement between observations and model is good.

Observational data on long-term trends in tropospheric $\mathrm{O}_{3}$ is relatively scarce. Oltmans et al. (2006) studied longterm changes from a network of surface and ozone sonde sites, finding significant regional differences in magnitude and even in the sign. Not only changes in emissions of ozone precursors, but also changes in transport patterns could influence the trends. In this work we use the same one-year of meteorological data for each simulation, excluding the possibility of changes in the transport pattern. Changes in the stratosphere, influencing both the transport of ozone rich air from the stratosphere, as well as photolysis, might also influence the trends in tropospheric $\mathrm{O}_{3}$ (Isaksen et al., 2005). The effect on tropospheric $\mathrm{O}_{3}$ due to historical changes in stratospheric $\mathrm{O}_{3}$, e.g. the observed decline in ozone at the South Pole and in the Arctic (Douglass et al., 2011) is not captured in the time slice simulations. In addition, there is a large interannual variability in stratospheric $\mathrm{O}_{3}$ (Randel and Thompson, 2011), which will influence the comparison with sonde observations. Oltmans et al. (2006) found a significant increase in the 1970s and 1980s over continental Europe and Japan, and thereafter the concentrations levelled off or declined. Figure 6 shows the modelled changes in ozone at the surface (Fig. 6a) and at $500 \mathrm{hPa}$ (Fig. 6b) between 1970 and 2000 in $\%$ decade $^{-1}$. Also shown are the time developments of regional mean surface ozone (Fig. 6c) and ozone at $500 \mathrm{hPa}$ (Fig. 6d). Looking at Fig. 6c and 6d, the concentration in Europe increased in the same period as in Oltmans et al. (2006) and flattened out and decreased during 


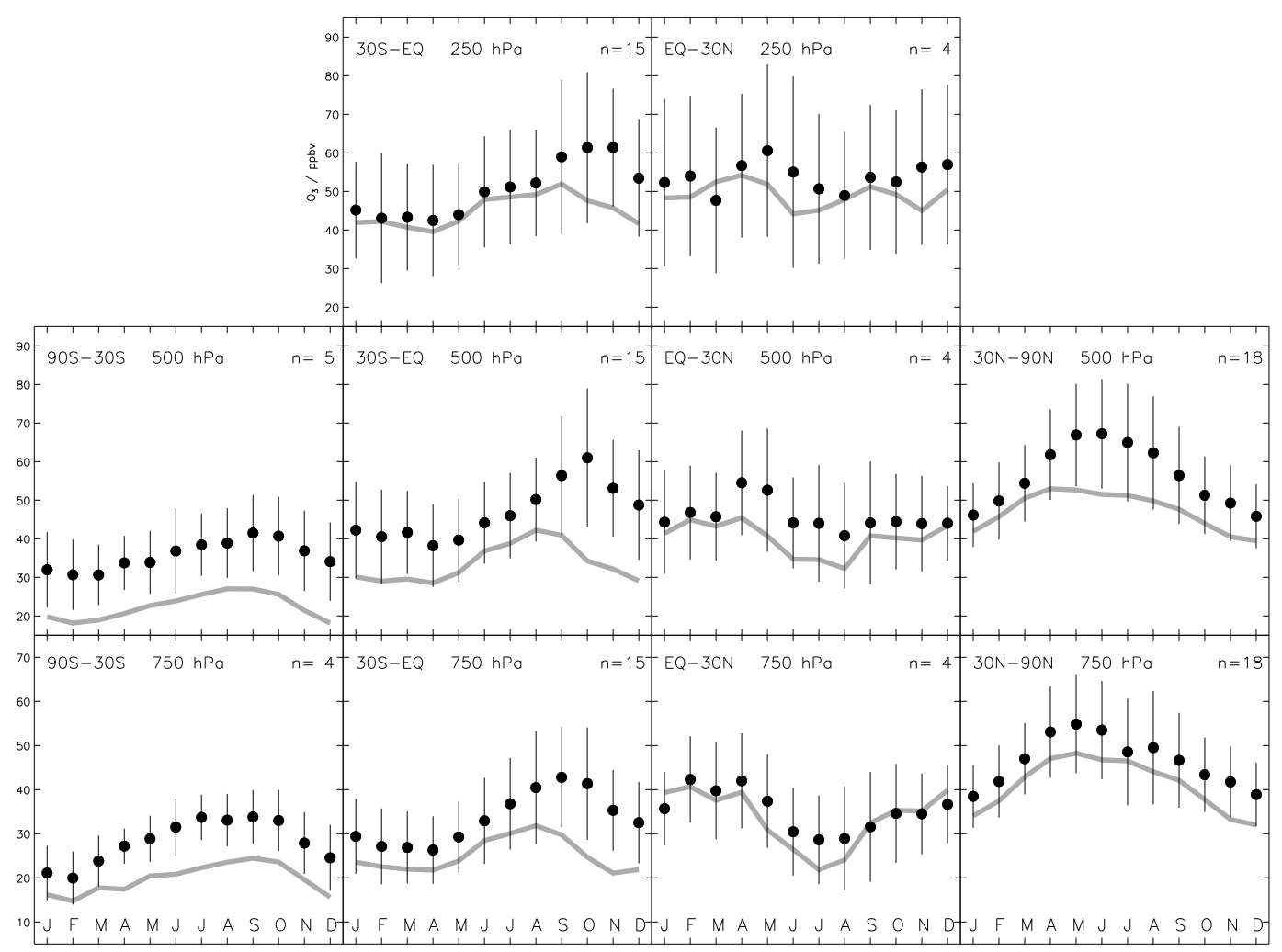

Fig. 5. Comparison of the annual cycle of ozone observations (black dots) and monthly mean $\mathrm{O}_{3}$ for the year 2000 simulation (gray lines) at different latitude bands and at different pressure levels $(750 \mathrm{hPa}, 500 \mathrm{hPa}$ and $250 \mathrm{hPa}) . \mathrm{O}_{3}$ sonde data are from Logan (1999) and Thompson et al. (2003a, b). The number of sites is given in the top right corner of each plot. The figure is similar as in the multi model study by Stevenson et al. (2006).

the last decades. In the model, the ozone concentrations increase more on the western coast than on the eastern coast of North America due to influence of emission increase in Eastern Asia in the recent decades (Fig. 6). A rapid increase in observed springtime tropospheric $\mathrm{O}_{3}$ is also observed at the US Pacific coast in the recent years (Parrish et al., 2004; Cooper et al., 2010) which is related to increased Asian emissions. Looking at Fig. 6b, the largest increase in ozone at $500 \mathrm{hPa}$ is in Middle East, South, South East and East Asia between 1970s and year 2000. However, no observed longterm trends in tropospheric $\mathrm{O}_{3}$ from these regions exist.

Lelieveld et al. (2004) published trends in $\mathrm{O}_{3}$ over the Atlantic from ship-borne measurements from 1977 to 2002. No significant increase in $\mathrm{O}_{3}$ at high latitudes was found, while larger trends in ozone are found at lower latitudes and in the SH. In the OsloCTM2, the largest trends in the Atlantic are found outside the North African coast with $0.15 \mathrm{ppb} \mathrm{yr}^{-1}$ between 1980 and 2000, a spatial pattern consistent with Lelieveld et al. (2004). However, the observed increase is $0.5 \mathrm{ppb} \mathrm{yr}^{-1}$ between $20-40^{\circ} \mathrm{N}$ a factor of $\sim 3$ larger than the modelled trend. It should be noted that the observations prior to 1995 are sparse in Lelieveld et al. (2004) and the trend may be influenced by the seasonal $\mathrm{O}_{3}$ trend.
One of the longest records of measured $\mathrm{O}_{3}$ is from Hohenpeissenberg, Germany $\left(11.0^{\circ} \mathrm{E}, 47.8^{\circ} \mathrm{N}, 985 \mathrm{~m}\right)$ and goes back to 1970. The modelled annual surface ozone for this station is plotted together with 12 month running mean of the surface observations in Fig. 7a. In the 1970s and 1980s, the model tends to over predict the observations, while better agreement is found for the last decade. At Arkona $\left(13.4^{\circ} \mathrm{E}\right.$, $54.7^{\circ} \mathrm{N}$ ) in Northern Germany at the Baltic Sea, surface measurements of $\mathrm{O}_{3}$ started in the 1950s (German Meteorological Service of the German Democratic Republic). Also here, the ozone increase in the 1970s is not as sharp as observed (Fig. 6b), however the pre-1972 Arkona data might not be consistent with the later period (Low et al., 1990) due to changes in measurement instruments.

In Switzerland, in Arosa $\left(9.7^{\circ} \mathrm{E}, 46.8^{\circ} \mathrm{N}, 1800 \mathrm{~m}\right) \mathrm{O}_{3}$ measurements were also made in the 1950s. The $\mathrm{O}_{3}$ concentration increased by a factor of 2.2 between 1950s and 1990 (Staehelin et al., 1994). From our model results the annual mean concentrations increased by only $45 \%$, from $32 \mathrm{ppb}$ in $1950 \mathrm{~s}$ to $46.5 \mathrm{ppb}$ in $1990 \mathrm{~s}$.

Further back in time, from the 19th century, measurements of tropospheric $\mathrm{O}_{3}$ based on Schonbein paper methods exist. High uncertainties due to calibration, humidity, and other 
(a) $\mathrm{O}_{3}\left[\%\right.$ decade $\left.^{-1}\right] 2000$ - 1970

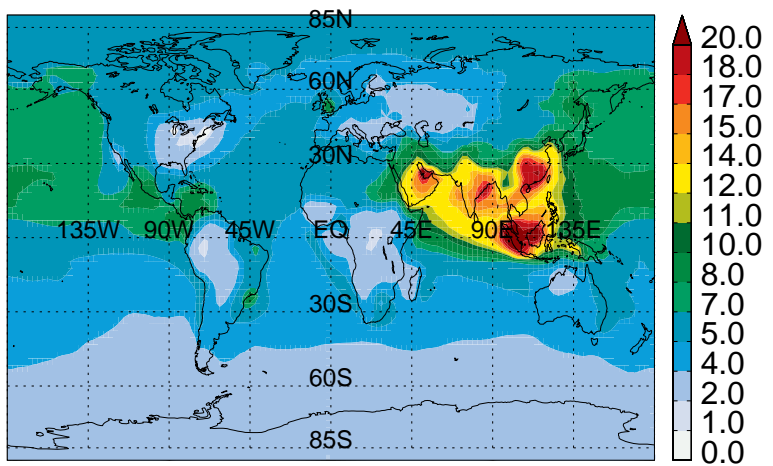

(b) $\mathrm{O}_{3}\left[\%\right.$ decade $\left.^{-1}\right] 2000-1970$

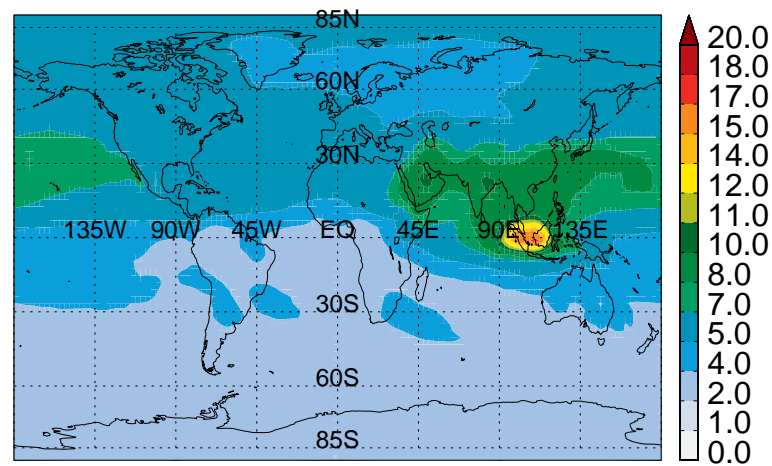

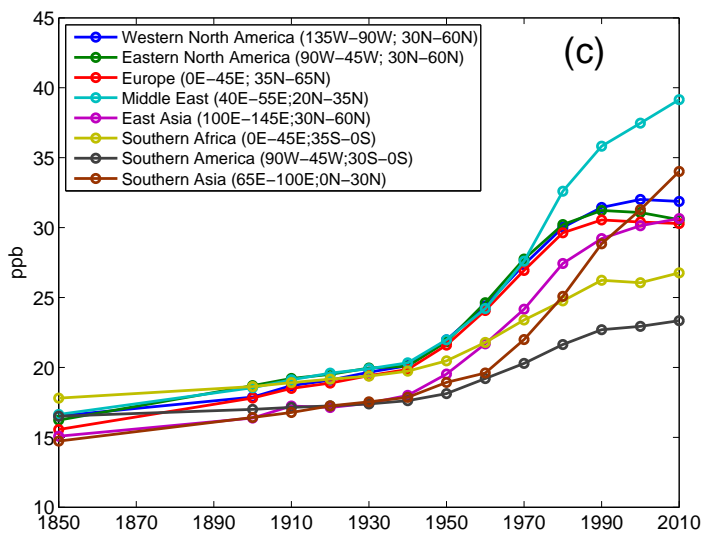

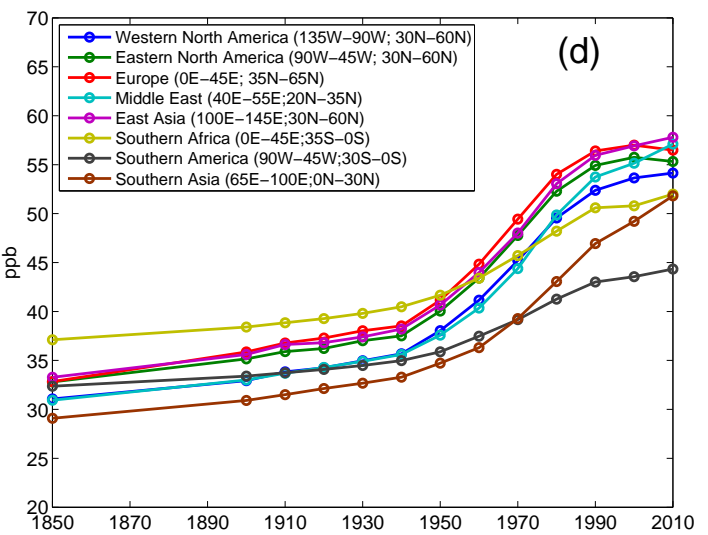

Fig. 6. Relative change from 1970 to $2000\left(\%\right.$ decade $\left.^{-1}\right)$ in surface $\mathrm{O}_{3}$ (a) and at approximately $500 \mathrm{hPa}(\mathbf{b})$ and time evolution of regional mean $\mathrm{O}_{3}$ at the surface (c) and approximately $500 \mathrm{hPa}(\mathbf{d})$.
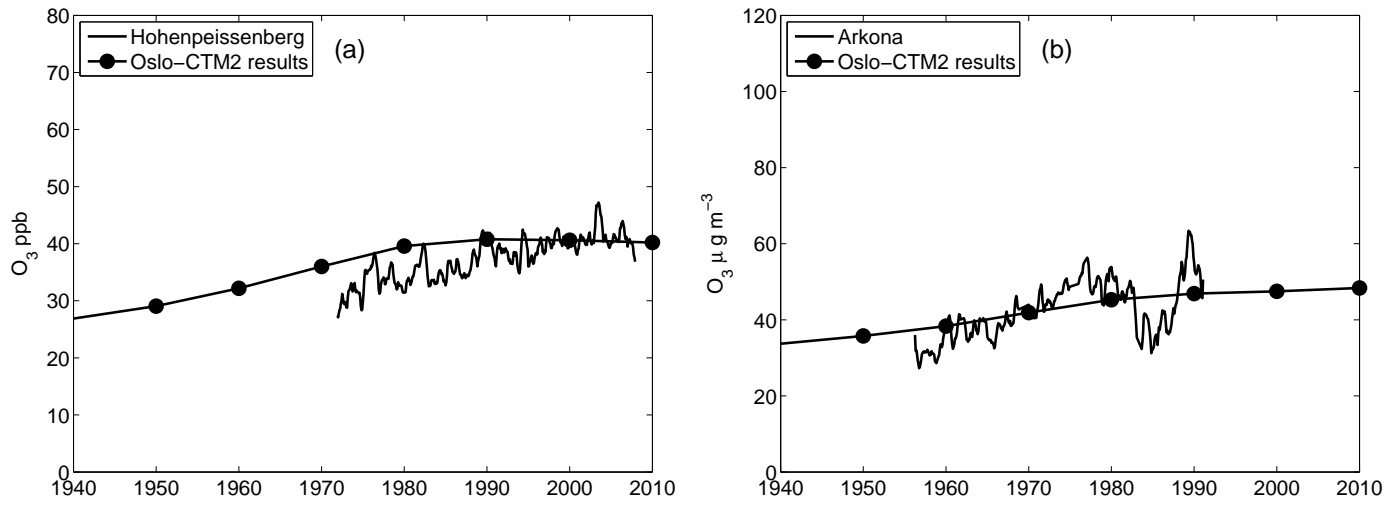

Fig. 7. Time series of surface $\mathrm{O}_{3}$ at Hohenpeissenberg (a) and Arkona (b). Annual mean model values (black dots) and 12-month smoothed average for the observations (solid line).

pollutants confounding the measurements make these measurements quantitatively unreliable (Pavelin et al., 1999). At Pic du Midi $\left(0.15^{\circ} \mathrm{E}, 49.9^{\circ} \mathrm{N}\right)$ in France at $3000 \mathrm{~m}$ altitude, there exist observed ozone from 1874 to 1909 (Marenco et al., 1994). A stable concentration of $10 \mathrm{ppb}$ was found until
1895 then concentration tends to increase. Combined with observed surface $\mathrm{O}_{3}$ in the 1990s, this gives a five fold concentration increase at this station. Marenco et al. (1994) summarized other measurement done in the 19th century giving a pre-industrial $\mathrm{O}_{3}$ level of $10 \pm 3.5 \mathrm{ppb}$. However in our model 
results, as in a number of previous model simulations (e.g. Wang and Jacob, 1998; Berntsen et al., 2000; Lamarque et al., 2005; Shindell et al., 2006a; Lamarque et al., 2010) we are not able to simulate these low values in the 19th century. As seen in Fig. 6c, the surface ozone in the regions considered ranged between 15 and $18 \mathrm{ppb}$ in 1850 . Mickley et al. (2001) showed that reducing the soil and lightning $\mathrm{NO}_{\mathrm{x}}$ emissions and increasing biogenic VOC emissions in the model gives a better match of the 19th century observations. If this is true, it still leaves open the question if the natural emission changes are climate feedbacks, and GCM simulations have shown increased lightning in a warmer climate (Price and Rind, 1994; Hauglustaine et al., 2005; Brasseur et al., 2006; Del Genio et al., 2007).

The uncertainty range in the tropospheric $\mathrm{O}_{3}$ radiative forcing in Forster et al. (2007) was skewed ranging from 0.25 to $0.65 \mathrm{~W} \mathrm{~m}^{-2}$ with a best estimate of $0.35 \mathrm{~W} \mathrm{~m}^{-2}$. This range took into account model results tuning the natural emissions to reproduce the low ozone values reported from the 19th century. Due to the large uncertainties in the measurements from the 19th century and that we consider changes in the natural emissions as a feedback on the climate system, we exclude those results where natural emissions were tuned, presenting a symmetric uncertainty range of $\pm 30 \%$ in Fig. 1d, $0.44 \pm 0.13 \mathrm{~W} \mathrm{~m}^{-2}$. Our tropospheric $\mathrm{O}_{3} \mathrm{RF}$ estimate includes $0.03 \mathrm{~W} \mathrm{~m}^{-2}$ from changes in the stratosphere due to tropospheric $\mathrm{O}_{3}$ precursors. Søvde et al. (2011) calculated chemistry in the whole stratosphere using the OsloCTM2 and found a stronger effect of $0.08 \mathrm{~W} \mathrm{~m}^{-2}$ in the stratosphere.

\subsubsection{The oxidation capacity}

The hydroxyl radical $(\mathrm{OH})$ is the major oxidation component in the atmosphere and has therefore a great impact on the concentrations of $\mathrm{CH}_{4}$ and the ozone precursors, thereby affecting tropospheric $\mathrm{O}_{3}$. In our model, the historical $\mathrm{CH}_{4}$ concentrations are however based on observed historical $\mathrm{CH}_{4}$ concentration.

Figure $2 \mathrm{e}$ shows the difference in the zonal annual mean concentration of $\mathrm{OH}$ between 1950 and 2000. There are two competing effects, an increase in $\mathrm{NO}_{\mathrm{x}}$ gives an increase in the $\mathrm{OH}$ concentration, and increases in $\mathrm{CH}_{4}$ and $\mathrm{CO}$ which reduce the $\mathrm{OH}$ concentration. Since the concentration change of $\mathrm{NO}_{\mathrm{x}}$ is greatest close to the surface in industrialized regions (Fig. 2c) while $\mathrm{CO}$ (Fig. 2d) and $\mathrm{CH}_{4}$ concentration changes are more evenly distributed in the atmosphere, the increase in $\mathrm{OH}$ is seen close to the surface, while in the free troposphere the $\mathrm{OH}$ is reduced (Fig. 2e).

In our simulations, the global average of $\mathrm{OH}$ concentration decreased by $15 \%$ from 1850 until year 2000 (Fig. 8). The largest rate of change is found between 1950 and 1960 with a decrease of $3 \%$ decade $^{-1}$. The concentration levelled off at the end of the simulation period, 1990-2010, at $1.1 \times 10^{6}$ molecules $\mathrm{cm}^{-3}$. Pozzoli et al. (2011) calculated

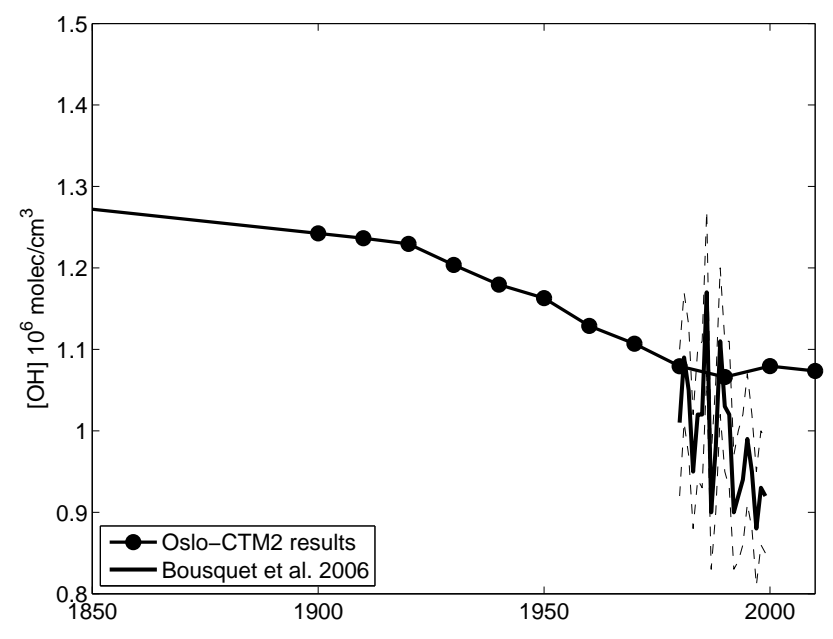

Fig. 8. Modelled annual mean global $\mathrm{OH}$ concentration (black dots) and derived $\mathrm{OH}$ concentrations (solid line) with uncertainties (dotted lines) from Bousquet et al. (2006).

changes in global $\mathrm{OH}$ concentration from 1980 to 2005 using the aerosol-chemistry-climate model ECHAM5-HAMMOZ. They found an increasing trend due to anthropogenic emissions of $0.25 \% \mathrm{yr}^{-1}$ which is greater than the relatively stable $\mathrm{OH}$ concentration in our study over this period (Fig. 8). Pozzoli et al. (2011) found that the anthropogenic trend was offset by a decreasing $\mathrm{OH}$ trend due to natural variability in meteorology (lightning, humidity and temperature) and natural emissions including biomass burning emissions emphasising the role of other factors than anthropogenic emissions on the $\mathrm{OH}$ concentration. The global mean $\mathrm{OH}$ concentration can be estimated based on observations of gases removed from the atmosphere by reactions with $\mathrm{OH}$. Bousquet et al. (2005) looked at the $\mathrm{OH}$ variability in the 1980s and 1990s using methyl chloroform observations. The inferred $\mathrm{OH}$ concentration from Bousquet et al. (2005) is added in Fig. 8. There is a large interannual variability in the inferred $\mathrm{OH}$ concentrations, but a downward trend is seen. The trend is larger than what we find in the model results. Recently, Montzka et al. (2011a), found that the $\mathrm{OH}$ concentration has been rather stable over the last decade, which is consistent with our model results (Fig. 8) and Pozzoli et al. (2011).

\subsection{Stratospheric ozone and water vapour}

In Fig. 1c the radiative forcing time series of stratospheric $\mathrm{O}_{3}$ is shown. The RF starts decreasing in the 1950s when concentrations of ozone depleting components in the stratosphere increases. The minimum RF is reached at the end of the 1990s, due to a reduction in the EESC at the end of the 20th century. The stratospheric $\mathrm{O}_{3} \mathrm{RF}$ in 2010 is $-0.23 \mathrm{~W} \mathrm{~m}^{-2}$ (Fig. 1d).

Our estimate accounts for changes in ozone due to ozone depleting components, occurring both in the stratosphere 
and in the troposphere. The RF presented in IPCC 2007 of $-0.05 \pm 0.1 \mathrm{~W} \mathrm{~m}^{-2}$ (Forster et al., 2007) is due to ozone changes in the stratosphere, and more recently Forster et al. (2011) presented a 1970 s to 2004 radiative forcing estimate of $+0.03 \mathrm{~W} \mathrm{~m}^{-2}$ based on observations and $-0.03 \pm 0.2 \mathrm{~W} \mathrm{~m}^{-2}$ based on chemistry climate models simulations, but stated that the estimates are not entirely of anthropogenic origin. Cionni et al. (2011) found a stratospheric $\mathrm{O}_{3}$ $\mathrm{RF}$ of $-0.08 \mathrm{~W} \mathrm{~m}^{-2}$, based on observations of stratospheric $\mathrm{O}_{3}$ from satellites and sonde data. The $\mathrm{RF}$ of stratospheric $\mathrm{O}_{3}$ changes given in Søvde et al. (2011) due to both chlorine and bromine and tropospheric $\mathrm{O}_{3}$ precursors was $-0.12 \mathrm{~W} \mathrm{~m}^{-2}$, within the ranges above but in the stronger range of previous studies. Radiative forcing estimates of ozone changes in the troposphere due to chlorine and bromine have not previously been published, but in Gauss et al. (2006), significant effects on tropospheric $\mathrm{O}_{3} \mathrm{RF}$ due to chlorine and bromine were seen. A subjective choice of an uncertainty bar of $\pm 70 \%$ is added in Fig. 1d for stratospheric $\mathrm{O}_{3} \mathrm{RF}$ giving a range of -0.07 to $-0.39 \mathrm{~W} \mathrm{~m}^{-2}$. Not included in this estimate is the effect of $\mathrm{N}_{2} \mathrm{O}$ on stratospheric $\mathrm{O}_{3}$, which was not considered in Søvde et al. (2011). A small RF of this effect of $-0.01 \mathrm{~W} \mathrm{~m}^{-2}$ was given in Forster et al. (2007) in Table 2.13.

The RF of stratospheric water vapour increases throughout the period, but flattens out over the last decades (Fig. 1c), as seen for the RF of $\mathrm{CH}_{4}$ as well. The RF is estimated by scaling the RF estimate for year 2005 in Forster et al. (2007) and the same relative uncertainties as in Forster et al. (2007) $( \pm 71 \%)$ is adopted. This gives a RF in 2010 of $0.073 \pm 0.052 \mathrm{~W} \mathrm{~m}^{-2}$ (Fig. 1d). The best estimate of stratospheric $\mathrm{H}_{2} \mathrm{O}$ RF is $2.6 \%$ of the RF of LLGHG in 2010.

\subsection{Aerosols}

In this section the changes in the aerosol concentrations and the direct aerosol effect for each aerosol component is first presented. In Sect. 3.4.6, the time series of the total direct aerosol effect and in Sect. 3.4.7 the indirect aerosol effects, both the cloud albedo effect and the cloud lifetime effect, are presented. The resulting RF time series are plotted in Fig. 1. The direct aerosol effect separated for each aerosol component is plotted in Fig. 1b, and we see that the two main aerosol components causing RF are sulphate and BC.

\subsubsection{Sulphate}

The total anthropogenic $\mathrm{SO}_{2}$ emission reached its maximum of $65 \mathrm{Tg} \mathrm{S}$ year $^{-1}$ in the 1980s (Table 1). The regional distribution of the emissions has changed over the 20th century, with a southward shift in the $\mathrm{SO}_{2}$ emissions in the last decades. At lower latitudes, the oxidation capacity of the atmosphere is higher (due to higher $\mathrm{OH}$ concentrations) and the emissions of oxidants precursors have also shifted southwards leading to a larger fraction of $\mathrm{SO}_{2}$ being oxidized to sulphate.
A summary of the global burden increase since 1750 is given in Table 2. As much as $36 \%$ of the total increase in sulphate burden occurred before 1950, mainly in early industrial areas in North America and Europe. Figure 9 shows the change in the burden and zonal mean concentrations between 1950 and 2000 for several aerosol components, as well as changes in regional burdens since 1850. The southward shift in the burden of $\mathrm{SO}_{4}$ is seen in Fig. 9a where the burden is reduced over Europe, North Atlantic and Eurasian Arctic, while the burden increased in the Middle East, South Asia and East Asia. The zonal mean concentration of sulphate increases south of $45^{\circ} \mathrm{N}$ throughout the troposphere while it mainly decreases in the north (Fig. 9b).

There was a particularly sharp increase in the sulphate burden over Europe from 1950 to 1970 (52\% decade ${ }^{-1}$ ) (Fig. 9c). After 1980 the burden over Europe has dropped and in year 2000 the burden was back to the 1950 level. For eastern North America, the burden has decreased since the 1970s. In the Middle East and East Asia, the burden increased gradually since the 1950s, while in South Asia the burden increased more rapidly.

The increase in sulphate burden in 2000 since 1850 was $0.44 \mathrm{TgS}\left(2.6 \mathrm{mg}\left(\mathrm{SO}_{4}\right) \mathrm{m}^{-2}\right)$, compared to the increase in burden of $0.36 \mathrm{TgS}\left(2.1 \mathrm{mg}\left(\mathrm{SO}_{4}\right) \mathrm{m}^{-2}\right)$ in Lamarque et al. (2010) who used the same emission inventory. In the AeroCom study (Schulz et al., 2006), the burden increase since pre-industrial times was $2.12 \mathrm{mg}\left(\mathrm{SO}_{4}\right) \mathrm{m}^{-2}$ (standard deviation of $0.82 \mathrm{mg}\left(\mathrm{SO}_{4}\right) \mathrm{m}^{-2}$ ). Summarizing previous studies, Schulz et al. (2006) found a larger increase in sulphate burden of $2.70 \mathrm{mg}\left(\mathrm{SO}_{4}\right) \mathrm{m}^{-2}$ (standard deviation of $1.09 \mathrm{mg}$ $\left(\mathrm{SO}_{4}\right) \mathrm{m}^{-2}$ ), which is in good agreement with our increase in burden in 2000 relative to 1750 of $2.79 \mathrm{mg}\left(\mathrm{SO}_{4}\right) \mathrm{m}^{-2}$.

The modelled maximum of the sulphate burden in our study occurred in the 1980s and 1990s, consistent with the study by Boucher and Pham (2002). Since the 1980s, the total (anthropogenic) emission of sulphur is reduced by $\sim 15 \%$ while the anthropogenic burden of $\mathrm{SO}_{4}$ is only reduced by $\sim 4 \%$. The southward shift in the emissions, to regions with higher oxidation capacity enhances the $\mathrm{SO}_{4}$ production efficiency, and the lifetime of $\mathrm{SO}_{4}$ remained fairly constant $( \pm 4 \%)$. As also was found in Berglen et al. (2007), the reduction of emissions of $\mathrm{SO}_{2}$ in Europe between 1985 and 1996 gave an increase in the efficiency of oxidation to sulphate. Similar results were also found by Pozzoli et al. (2011) for the period 1980 to 2005 with an almost unchanged global mean burden between a simulation with varying and fixed anthropogenic emissions.

Figure 10 compares observations and corresponding model results for several aerosol types. The figure shows decadal median of annual mean concentrations compared to the corresponding model results. Only the sites that have measurements in the 1980s, 1990s and 2000s are included. Sulphate is compared with observations from the EMEP network in Europe (Fig. 10a) and with observations from the IMPROVE network in the United States (Fig. 10b). For 
(a) 2000-1950 Sulphate $\mathrm{mg} \mathrm{m}^{-2}$

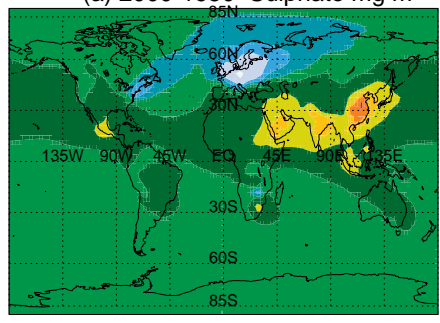

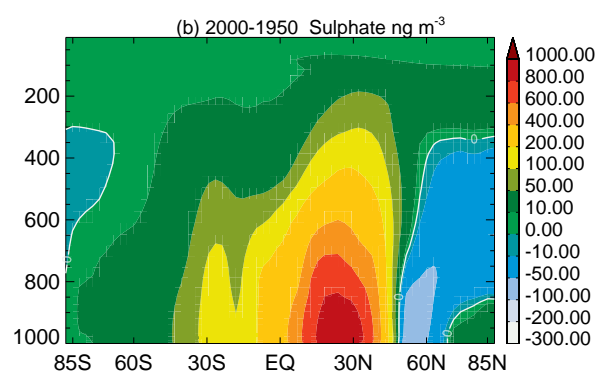

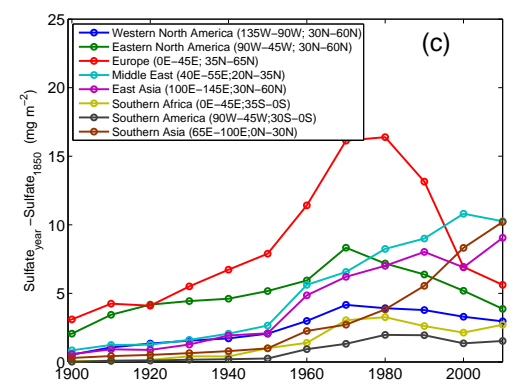

(d) 2000-1950 OC FFBF $\mathrm{mg} \mathrm{m}^{-2}$
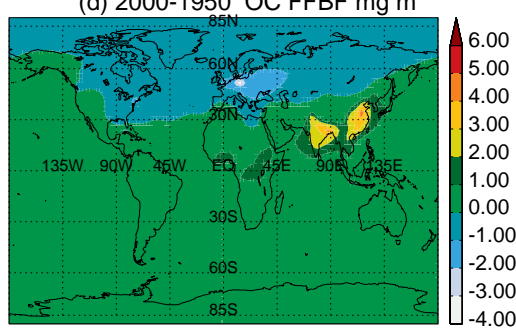

(g) 2000-1950 OC BB mg m²
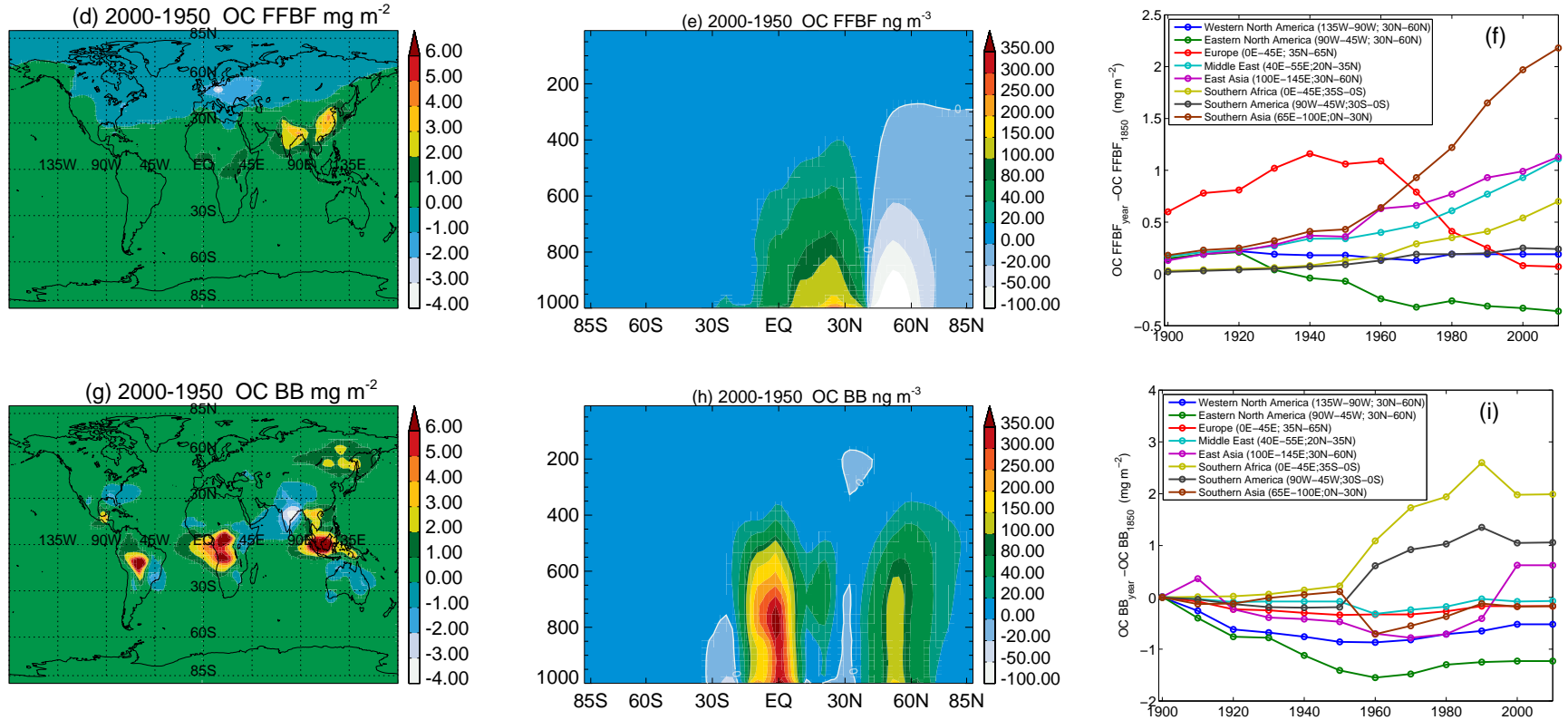

(j) 2000-1950SOA $\mathrm{mg} \mathrm{m}^{-4}$
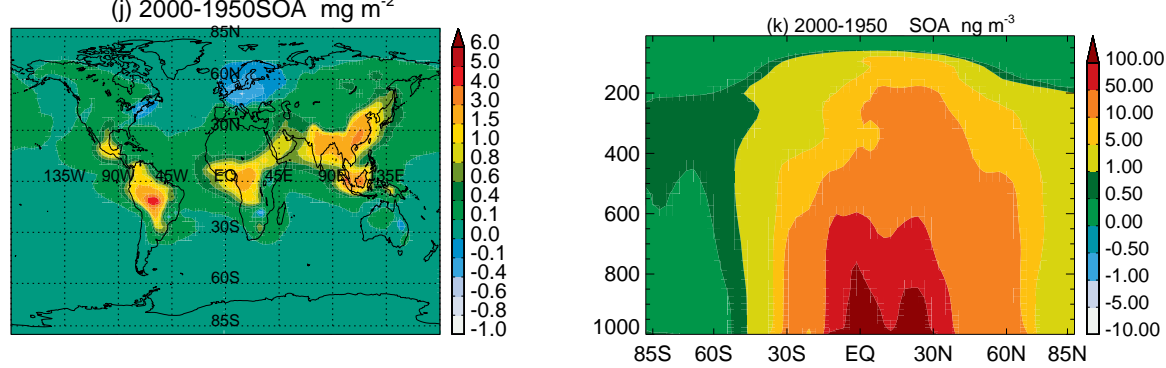

(m) 2000-1950 Fine mode nitrate $\mathrm{mg} \mathrm{m}^{-2}$
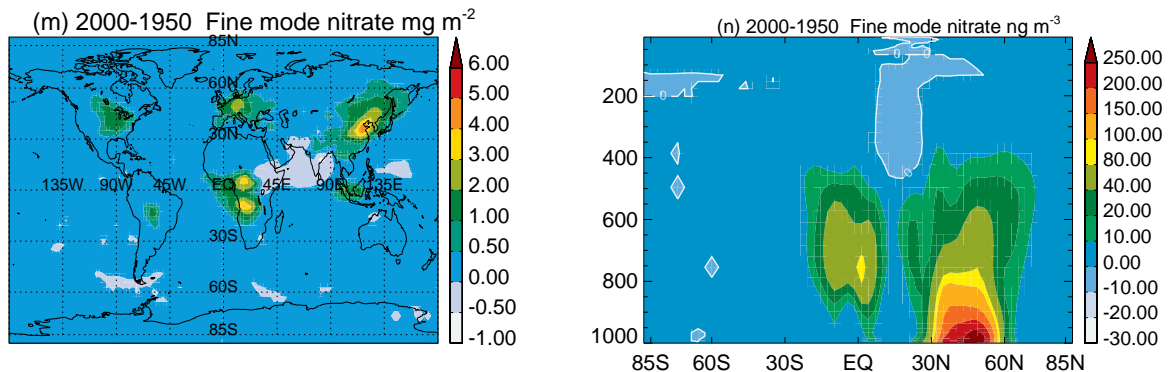
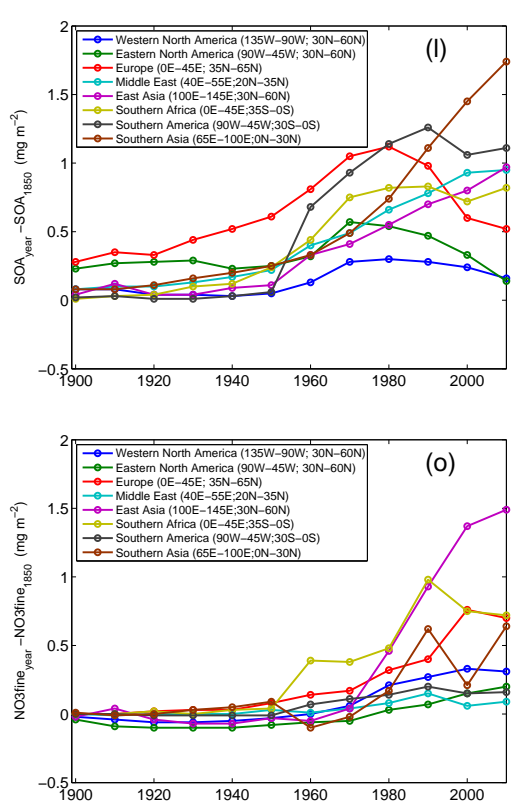

Fig. 9. The 2000-1950 difference in annual mean column load (left column) and annual zonal mean concentration (middle column). The development in regional burden relative to 1850 is shown in the right column. The aerosols included are sulphate, FFBF OC, BB OC, SOA and fine mode nitrate. 

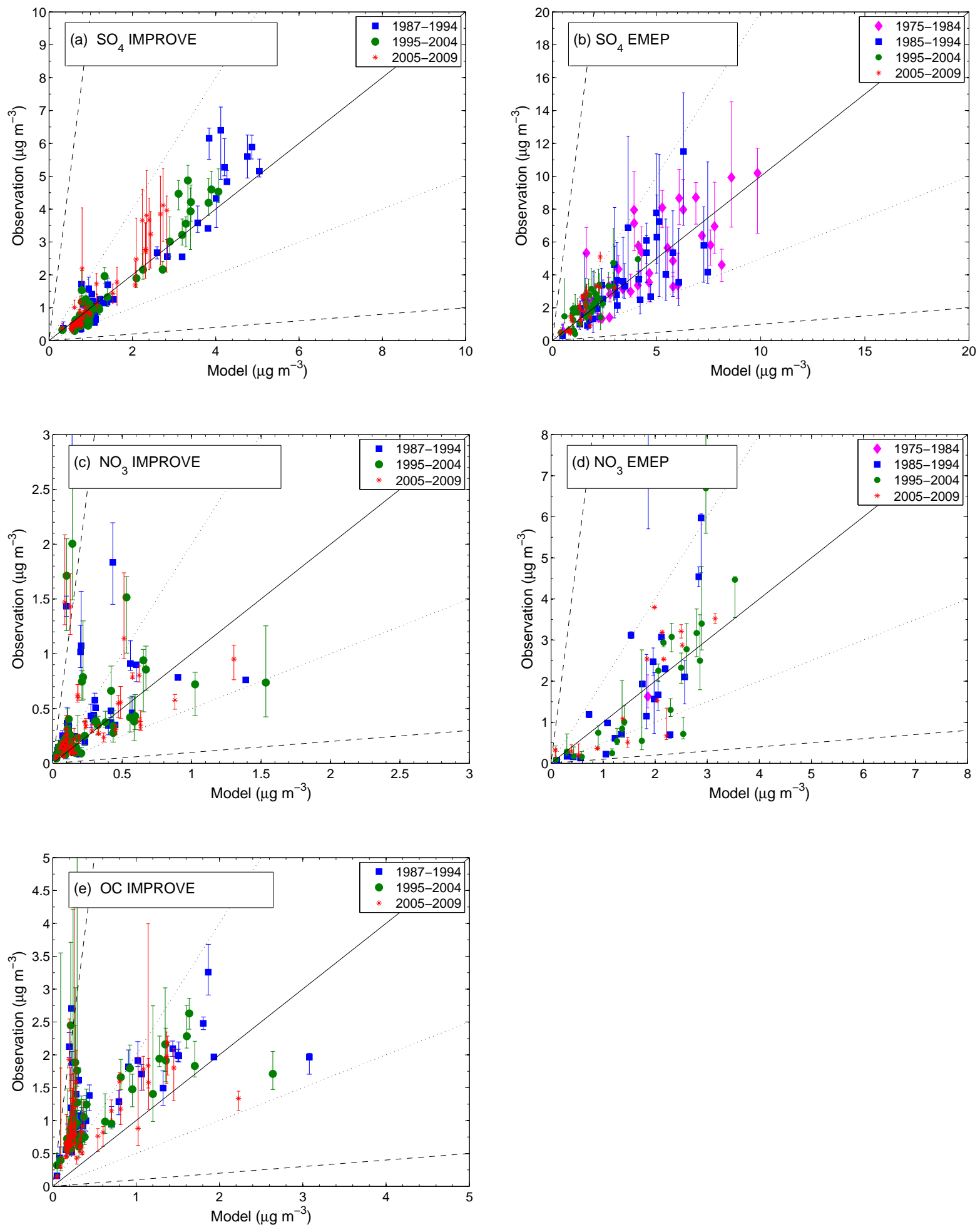

Fig. 10. The median of the observed annual means from the IMPROVE and EMEP networks compared with the corresponding modelled annual means for sulphate (a, b), nitrate (c, d) and OC (e) for each decade. The solid line shows a one-to-one correspondence. The dotted lines show a factor of 2 difference and the dashed lines a factor 10 difference between the observations and model results. The error bars added to the observations denote the maximum and minimum of the annual means in the decade. 


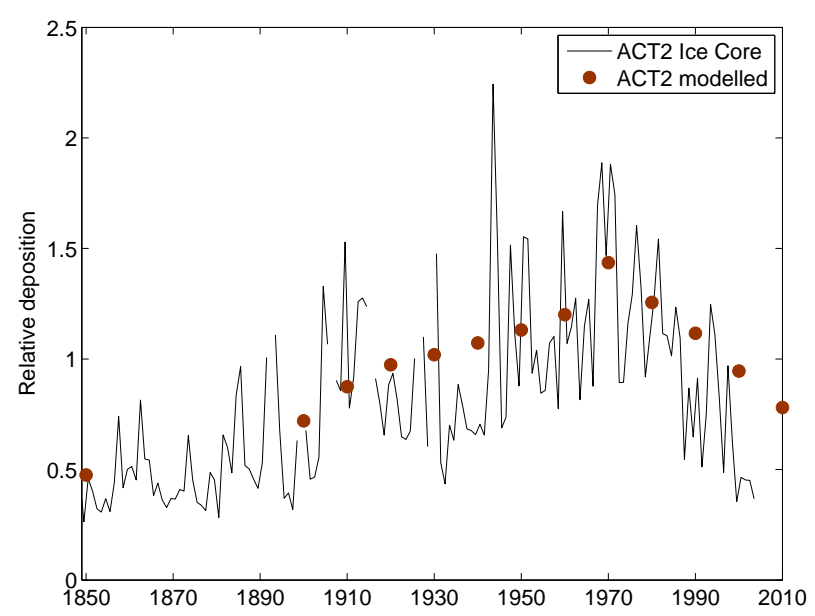

Fig. 11. Modelled relative deposition of sulphur (red dots) and relative deposition of sulphur from ACT2 ice core (solid line) in Greenland (McConnell and Edwards et al., 2008). The annual depositions are plotted relative to the mean deposition between 1900 and 2000.

both Europe and North America, the model results compares well with the observations, and the downward trend in the observed concentrations is clearly seen and captured by the model.

For longer term trends in sulphate, deposition data from ice cores at Greenland exist. Annual mean deposition relative to the mean deposition over the 20th century are shown in Fig. 11, both for our model results and ACT2 ice core (McConnell and Edwards, 2008). The model does not reproduce the absolute deposition values, which are a factor of 4.5 higher in the model than in the observations. The modelled deposition of sulphate decrease almost linearly towards the north with 3 times less deposition $1000 \mathrm{~km}$ to the north of ACT2. Due to the coarse grid of the model $(\sim 280 \mathrm{~km})$, too little deposition may occur at the edge of Greenland and hence too much sulphate will be transported to the Greenland plateau. However, the modelled trend of the deposition on Greenland is very good and the decline since 1970s is captured (Fig. 11).

The direct aerosol effect of sulphate dominates in the $\mathrm{NH}$ (Fig. 3b). Since 1980, the RF north of $30^{\circ} \mathrm{N}$ is reduced, and the southward shift in RF is clearly seen, with a maximum RF at $40^{\circ} \mathrm{N}$ prior to 1980 , and a broader maximum around $30^{\circ} \mathrm{N}$ in 2000 and 2010, related to the decrease in burden in Europe and the increase in Eastern Asia in the recent decades.

The global mean RF time series of $\mathrm{SO}_{4}$ are plotted in Fig. 1b, showing a rapid increase in between 1950 and 1980 and flattening out thereafter. The RF in year 2000 was $-0.60 \mathrm{~W} \mathrm{~m}^{-2}$ and a slightly stronger $\mathrm{RF}$ of $-0.62 \mathrm{~W} \mathrm{~m}^{-2}$ was found in 2010 , which is in the upper range of $-0.4 \pm 0.2 \mathrm{~W} \mathrm{~m}^{-2}$ presented by Forster et al. (2007) for year 2005. The maximum direct aerosol effect of sulphate occurred in 1980 and 1990 with $-0.65 \mathrm{~W} \mathrm{~m}^{-2}$.

\subsubsection{Black carbon}

In Skeie et al. (2011) the FFBF BC RF time series from 1750 until 2000 is presented using the same model but a different emission inventory, namely Bond et al. (2007). In this study the FFBF BC emissions in year 2000 was $5.0 \mathrm{Tg}$ (Table 1) while in Skeie et al. (2011) the total FFBF emission was $4.5 \mathrm{Tg}$. An updated version of Bond et al. (2007) is used in Lamarque et al. (2010). In the latter part of the 20th century, the emissions increased more rapidly in Lamarque et al. (2010) compared to Bond et al. (2007). Therefore, the burden increase and hence the radiative forcing is larger in this study compared to Skeie et al. (2011). Between 1950 and 2000 the burden increased by $0.05 \mathrm{Tg}$ in this study (Table 2), while it increased by $0.035 \mathrm{Tg}$ in Skeie et al. (2011). The best estimate of FFBF BC radiative forcing in Skeie et al. (2011) for 2000 was $0.35 \mathrm{~W} \mathrm{~m}^{-2}$ and in this study the RF in 2000 was $0.43 \mathrm{~W} \mathrm{~m}^{-2}$. The time series of FFBF BC radiative forcing from this study is included in Fig. $1 \mathrm{~b}$ and from the zonal mean RF plot (Fig. 3c) a southward shift in the RF at the end of the 20th century is seen.

\subsubsection{Organic aerosols}

Organic aerosols can be emitted directly as primary particles (OC) or formed in the atmosphere by condensation of oxidized volatile components on existing aerosols (secondary organic aerosols, SOA). As shown in Table 1, the direct emission of OC from fossil fuel and biofuel sources reached a maximum in 2000, and for biomass burning sources the maximum in global emissions occurred in 1990.

The emissions of VOCs contributing to SOA formation used in this study are also listed in Table 1. The emissions of biogenic VOCs are assumed to be constant for all time slice simulations to separate the anthropogenic signal, while anthropogenic VOCs have increased over the period with a maximum in 1990. The anthropogenic emissions are small compared to the biogenic emissions, and as Hoyle et al. (2009) pointed out, the changes in anthropogenic VOCs have a minor direct contribution to the change in the SOA burden. For SOA production, not only the emissions of SOA precursors are important, but also the oxidation capacity of the atmosphere and the surface area of aerosols available for condensation of oxidation products. In this study SOA can form on both existing OC and sulphate aerosols.

The increase in global burden in 2000 since pre-industrial times was $195 \mathrm{Gg}$ for FFBF OC, $338 \mathrm{Gg}$ for OC BB and $230 \mathrm{Gg}$ for SOA (Table 2) where SOA is given in organic matter (OM). Factors for conversion of OC to mass of OM have been reviewed by Turpin and Lim (2001). They presented a conversion factor of $1.6 \pm 0.2$ for urban aerosols, $2.1 \pm 0.2$ for non urban aerosols and 2.2-2.6 for biomass burning aerosols. Using a factor of 1.6 for FFBF OC and 2.6 for OC BB gives a $16 \%$ contribution of SOA to the increase in burden of total organic matter in 2000. Schulz et 
al. (2006) reported an increase in particulate organic matter of $1.32 \mathrm{mg} \mathrm{m}^{-2}$ (standard deviation $0.32 \mathrm{mg} \mathrm{m}^{-2}$ ) from the AeroCom simulations and $2.40 \mathrm{mg} \mathrm{m}^{-2}$ (standard deviation of $0.39 \mathrm{mg} \mathrm{m}^{-2}$ ) from other published estimates. Using the same factors as above we find an increase in burden of organic matter in year 2000 of $2.79 \mathrm{mg} \mathrm{m}^{-2}(1.42 \mathrm{Tg})$ including SOA and $2.34 \mathrm{mg} \mathrm{m}^{-2}(1.19 \mathrm{Tg})$ excluding SOA, a larger increase than in the AeroCom simulations but in agreement with other previous published studies summarized in Schulz et al. (2006).

In Hoyle et al. (2009), the burden increase of SOA since 1750 was $260 \mathrm{Gg}$ when partitioning on sulphate aerosols was allowed, larger than in this study (Table 2), which can be explained by differeces in loading of sulphate and OC. Other studies calculating the change in SOA burden from preindustrial times until present are Chung and Seinfeld (2002) with $130 \mathrm{Gg}$ increase, Liao and Seinfeld (2005) with $100 \mathrm{Gg}$ increase and Tsigaridis et al. (2006) with $160 \mathrm{Gg}$ increase. The increases in SOA burden from these models are less than what is calculated using OsloCTM2, although the relative change in Chung and Seinfeld (2002) was greater. The differences among the models, mainly related to the amount of mass available for partitioning, meteorological data, removal schemes, and biogenic VOC, are discussed in detail in Hoyle et al. (2009).

The time development of global mean burden over the 20th century differs for FFBF OC, OC BB and SOA. For FFBF OC, the global mean burden increased almost linearly throughout the century, while for OC BB, the burden was higher in the early 20th century and decreased towards 1950 before increasing again until 1990 following the global emissions (Table 1). Between 1850 and 1950 the SOA burden increased almost linearly by $1 \%$ decade $^{-1}$ and after 1950 the burden increased rapidly with $36 \%$ decade $^{-1}$ until 1990 and being stable thereafter (Table 2).

Looking at the geographical distribution of the burden change, the burden of FFBF OC is reduced over a greater area in North America and Europe since 1950 (Fig. 9d), and the FFBF OC burden is shifted southwards as clearly seen in the zonal mean concentration change plot (Fig. 9e). Biomass burning OC burden has increased in South America, Africa and Indonesia since 1950 (Fig. 9g).

For SOA (Fig. 9m), a slight reduction in burden is found over the north eastern coast of the US and in Northern Europe between 1950 and 2000, related to the decrease in burden of $\mathrm{SO}_{4}$ (Fig. 9a) and OC (Fig. 9d) in these regions. An increase in the SOA burden is found in South America, Africa, South-, Southeast- and East Asia (Fig. 9m), where the burdens of $\mathrm{OC}$ and $\mathrm{SO}_{4}$ have also increased. For the zonal mean, the concentration of SOA increased between 1950 and 2000 (Fig. 9k) for the whole domain. Two maxima are found close to the surface, at the equator related to biomass burning, and at $20^{\circ} \mathrm{N}$ related to fossil fuel aerosols. The increase in SOA stretches to a higher altitude than that of FFBF OC and $\mathrm{OC} \mathrm{BB}$, due to the secondary character of SOA and a larger fraction of the oxidised organic components shifting to the aerosol phase at cold temperatures.

Looking at the regional development of the organic aerosols, the FFBF OC burden decreased in Northern America since the 1920s (Fig. 9f). In Europe, the burden increased until 1940 and decreased rapidly between 1960 and 2000 . The most rapid increase was in South Asia, after 1950, but the regional burden also increased in East Asia, the Middle East and South Africa in the latter part of the 20th century. For SOA, the burden increased in Europe until 1980 (Fig. 91). For the other regions, the burden change between 1900 and 1950 was small, possible due to decreasing OC BB and increasing sulphate and FFBF OC burden. In Southern America, the burden increased rapidly from 1950 to 1960 and continued to increase until 1990. This is related to a large increase in the OC BB in this region (Fig. 9i).

How well are the organic aerosols modelled? Modelled concentrations from the OsloCTM2 for the present day situation are compared with surface observations in Myhre et al. (2009) and Hoyle et al. (2007). The OsloCTM2 underestimates organic aerosols at most of the stations, even when all semi-volatile species are partitioned to the aerosol phase. Hoyle et al. (2007) suggested too low primary organic aerosols concentrations as one possible reason for the underestimation, as well as sub-grid scale concentration gradients.

Long-term time series of OC measurements are only available from the IMPROVE network. In Fig. 10e the observed OC concentrations are compared with modelled OC concentrations assuming SOA concentration divided by the factor of 1.6 gives the carbon content. We see that the model tends to under predict and grossly underestimate at several sites where the modelled concentrations of OC are very low. The best agreement is found for stations in eastern US, while the worst agreement is found for stations in the north western US. The underestimation is larger than in Myhre et al. (2009) and Hoyle et al. (2007) where modelled and observed concentrations corresponding to the same year was compared. One reason for the underestimation in this study may therefore be that we compare model results and observations for different years. The meteorological situation influences the observed concentrations, and biomass burning emissions are highly variable. The OC burden in Hoyle et al. (2007) is higher due to larger emissions and the use of a longer aging time for conversion of OC from hydrophobic to hydrophilic aerosols.

In this section we focus on the radiative forcing of FFBF OC and SOA. Radiative forcing time series of biomass burning aerosols will be presented in Sect. 3.4.4. As we saw for FFBF BC, the RF of FFBF OC is shifted southwards in the latter part of the 20th century (Fig. 3d). For SOA there are a broad maximum in RF between $10^{\circ} \mathrm{S}$ and $20^{\circ} \mathrm{N}$ in 2000 (Fig. 3e), related to RF in South America, Africa and Eastern Asia.

The RF time series of FFBF OC and SOA is plotted in Fig. 1b. The calculated RF in 2010 for FFBF OC was 
$-0.13 \mathrm{~W} \mathrm{~m}^{-2}$ and for SOA $-0.09 \mathrm{~W} \mathrm{~m}^{-2}$. Compared to a previous study using the OsloCTM2, the calculated RF of SOA was $-0.09 \mathrm{~W} \mathrm{~m}^{-2}$ when SOA was allowed to partition on both organic and sulphate aerosols, and $-0.06 \mathrm{~W} \mathrm{~m}^{-2}$ if only allowing for partitioning on organic aerosols (Hoyle et al., 2009). As discussed in Hoyle et al. (2009), the partitioning of semi-volatile organic species to sulphate aerosol is oversimplified in the OsloCTM2, because it is assumed that this partitioning is as efficient as to organic aerosols. In reality, the initial partitioning of organics to sulphate aerosols is likely to be less than to organic aerosols. However, acid catalysed condensed phase reactions have the potential to reduce the volatility of some organic species, leading to substantially increased partitioning to the acidic aerosol (Hoyle et al., 2011a and references therein). Until more research has been done into how these effects can be quantified in a way suitable for inclusion in large scale models, we believe that our current approach is an acceptable approximation. Modelled concentrations better match the observations when condensation on sulphate is allowed than when only allowing partitioning to the primary organic aerosols (Hoyle et al., 2007; Myhre et al., 2009).

If combining FFBF OC and SOA the RF in year 2010 is $-0.22 \mathrm{~W} \mathrm{~m}^{-2}$. It is substantially stronger compared to the RF of organic aerosols presented in Forster et al. (2007) of $-0.05 \pm 0.05 \mathrm{~W} \mathrm{~m}^{-2}$, where most of the estimates considered did not include SOA chemistry. The RF due to primary OC is also strengthened due to a combination of larger burden and an increased ratio of OM/OC more in line with observations as discussed in Myhre et al. (2009). The RF of organic aerosols (FFBF OC and SOA) is $35 \%$ of the sulphate direct aerosol forcing (with the same sign) and $44 \%$ of the BC direct aerosol forcing (with opposite sign).

\subsubsection{Biomass burning aerosols}

For open biomass burning, we combine organic carbon and black carbon aerosols (OC BB and BC BB) and calculate one single RF since the composition of the aerosols cannot be controlled (Forster et al., 2007).

The emissions are assumed constant between 1850 and 1900, due to lack of information (Lamarque et al., 2010). From 1900 until 1950 the global emissions were reduced due to a decrease in forest clearing at mid-latitude and improvements of fire fighting systems. From 1950 until 1990 the emission increased, as a result of deforestation in the tropics. From 1990 until 2000, the emissions from tropical regions are reduced leading to global emission reduction (Table 1). The global mean burdens of OC BB and BC BB decreased from 1900 towards 1950, and increased until 1990 (Table 2).

The change between 1950 and 2000 in the burden of OC (equal pattern for BC) from biomass burning (Fig. $9 \mathrm{~g}$ ) is positive and most pronounced in tropical areas in South America, Africa and Indonesia, while the burden decreased in Eastern US, India, Australia and eastern part of South Amer- ica and Africa. In boreal areas in Siberia/China and North America the burden has increased. This change at high latitude is largely due to the increase in the emissions in the last decade from 1990 until 2000.

The pattern of the zonal mean RF has changed over the 20th century (Fig. 3e). In the tropics, the RF is negative due to the increase in emissions and dominance of BB OC. At high latitude the RF is positive and it increased between 1980 and 2000. This is due to the large emission increase in this region and higher absorption efficiency due to the higher reflective surfaces and higher cloud fractions at high latitudes compared to lower latitudes.

The RF is calculated based on concentration changes relative to the pre-industrial values. The pre-industrial emissions are difficult to estimate, as well as emissions in the presatellite era. For aerosols detailed information from satellites are not obtained prior to the launch of MODIS/Multiangle Imaging Spectro Radiometer (MISR) in late 1999. Information on historical burned area and vegetation and carbon available for combustions is highly uncertain (Mouillot et al., 2006; Mieville et al., 2010). Analysis of ice- and sediment cores may give information on historical trends in biomass burning emissions. Wang et al. (2010) analyzed an Antarctic ice core and presented concentrations of $\mathrm{CO}$ from biomass burning using isotope records. The results indicated that present day $\mathrm{CO}$ from biomass burning in the $\mathrm{SH}$ is lower than at any time during the last $650 \mathrm{yr}$, with a minimum in $1600 \mathrm{~s}$, an increase until late $1800 \mathrm{~s}$, and a decrease by $70 \%$ from late 1800s until present day. This confirms the results from Marlon et al. (2008) who derived a tropical charcoal index from sediment cores in both hemisphere and found a similar pattern with an abrupt decline in the global burning after 1870. This is in contradiction to what is previously assumed about biomass burning emissions (Ito and Penner, 2005). In the emission inventory used in this study (Lamarque et al., 2010), the global emissions did decrease from the 1900 until 1950, and then increased, being $33 \%$ higher in 2000 than in 1900. The pre-industrial biomass burning emissions assumed in this study was $50 \%$ of the 1850 emissions, approximately $40 \%$ of the year 2000 emissions. From Wang et al. (2010) and Marlon et al. (2008) a sharp increase in biomass burning between 1750 and 1850 is reasonable, however the magnitude is highly uncertain.

In Fig. $1 \mathrm{~b}$ the time series of RF of biomass burning aerosols are presented. The RF increased between 1900 and 1950 due to the emission reduction at mid-latitudes, while it further decreased after 1950 due to tropical deforestation. In 2010 the RF is $-0.07 \mathrm{~W} \mathrm{~m}^{-2}$, in the lower range of the RF estimate of $+0.03 \pm 0.12 \mathrm{~W} \mathrm{~m}^{-2}$ in Forster et al. (2007).

\subsubsection{Nitrate}

Concentrations of fine-mode nitrate aerosols (mainly ammonium nitrate) are governed by precursor emissions $\left(\mathrm{NH}_{3}\right.$ and $\mathrm{NO}_{\mathrm{x}}$ ), photochemistry (oxidation of $\mathrm{NO}_{\mathrm{x}}$ to $\mathrm{HNO}_{3}$ ), ambient 
sulphate levels and meteorological conditions (temperature, wet scavenging rates, etc.) (Metzger et al., 2002). Both $\mathrm{NH}_{3}$ and $\mathrm{NO}_{\mathrm{x}}$ emissions (and thus $\mathrm{HNO}_{3}$ concentration, Fig. 2f) increased between 1950 and 2000 (Table 1). However, ammonium prefers to be associated with sulphate suppressing nitrate aerosol formation, and the $\mathrm{SO}_{2}$ emission has increased over the 20th century, reaching a maximum in 1980 (Table 1).

The change in fine-mode nitrate aerosols burden between 1950 and 2000 is shown in Fig. 9m. The increase is only seen over continental areas, since nitrate aerosols associated with coarse mode sea salt dominates over the oceans.

The main increase in fine-mode nitrate occurred in Eastern Asia from 1960 and onwards (Fig. 9o), where both finemode ammonium burden (not shown) and sulphate burden (Fig. 9c) increased. Fine-mode nitrate in biomass burning regions in Africa has increased since 1950, reaching a maximum in 1990s. This increase occurred in the free troposphere as nitrate aerosol formation is favoured at lower temperatures (Fig. 9n).

In Europe, the sulphate burden has decreased dramatically between 1980 and 2000 (Fig. 9c). The modelled fine-mode ammonium has however also decreased in the same time period (not shown), but in total, the fine-mode nitrate burden in Europe increased between 1980 and 2000 (Fig. 9o).

In South Asia the fine-mode nitrate burden was almost the same in 1950 and 2000 (Fig. 9m), however looking at the development of the regional burden we can see that the regional burden in South Asia is much lower in 2000 than in 1990 and 2010. This is related to lower agricultural $\mathrm{NH}_{3}$ emissions in this region in year 2000 compared to 1990 and 2010. This needs further investigation, to determine if the reduction in emissions between 1990 and 2000 in South Asia is real.

As we have seen for the other components, a sharp increase in global burden of fine-mode nitrate occurred since 1950 (Table 2), with $95 \%$ of the total increase after 1950. For fine-mode ammonium aerosols, $74 \%$ of the burden increase since 1750 occurred after 1950. Compared to a previous study using OsloCTM2 (Myhre et al., 2009), the anthropogenic burden increase was $13 \mathrm{GgN}\left(0.11 \mathrm{mg} \mathrm{m}^{-2}\right)$ lower than the burden increase of $24 \mathrm{Gg} \mathrm{N}$ between 1750 and 2000 in this study.

The total burden (anthropogenic plus natural) of fine-mode nitrate in year 2000 was $0.026 \mathrm{Tg}$ N. This is much lower than $0.11 \mathrm{Tg} \mathrm{N}$ from the GISS climate model reported by Bauer et al (2007), who did not consider sea salt in their simulation, but they included nitrate associated with dust with burden of $0.41 \mathrm{Tg} \mathrm{N}$. In this study the total fine-mode $(0.026 \mathrm{Tg} \mathrm{N})$ plus coarse mode nitrate burden $(0.23 \mathrm{Tg} \mathrm{N})$ in year 2000 was $0.25 \mathrm{Tg}$ N.

The modelled $\mathrm{NO}_{3}$ aerosols are compared with observations from the IMPROVE network (Fig. 9c) and the EMEP network (Fig. 9d) for the last decades. The modelled fine and coarse mode aerosols are compared with the EMEP aerosol observations, while the fine-mode aerosols and $15 \%$ of the coarse mode aerosols are compared with the IMPROVE aerosol observations as done in Myhre et al. (2009). For the North American observations the model underestimates some high observed values (Fig. 9c). In Europe, the model overestimates low observed values in Norway and Russia (Fig. 9d).

The RF time series of nitrate is plotted in Fig. 1c and the zonal distribution in Fig. 3g. As for the other aerosol components the magnitude is increasing from 1950s and levelling off during the last decades. In 2010 the $\mathrm{RF}$ is $-0.046 \mathrm{~W} \mathrm{~m}^{-2}$, only $7.4 \%$ of the RF of sulphate. This is stronger than the nitrate $\mathrm{RF}$ of $-0.023 \mathrm{~W} \mathrm{~m}^{-2}$ from Myhre et al. (2009) and weaker then the RF in Bauer et al. (2007) of $-0.06 \mathrm{~W} \mathrm{~m}^{-2}$ for 2000 relative to 1750 . Our estimate is in the weaker part of the IPCC 2007 range of $-0.1 \pm 0.1 \mathrm{~W} \mathrm{~m}^{-2}$ (Forster et al., 2007), however our model takes into account sea salt in the equilibrium calculations, which reduce the burden of fine mode nitrate.

\subsubsection{Direct aerosol effects}

For the total direct aerosol effect, the two main components are sulphate and FFBF BC which have opposite sign (Fig. 1b). The total direct aerosol effect strengthens rapidly in the middle of the 20th century, and then the RF flattens out and slightly weakens in the recent decades (Fig. 1c). The sum of the RF of each of the aerosol components gives a slightly weaker RF than when the total direct aerosol effect is calculated (Fig. 1c), due to non-linearities arising from scattering and absorbing aerosols.

The time development of the zonal mean RF is shown in Fig. 3h. The negative sulphate forcing dominates, except at high latitudes where the total direct aerosol effect is positive due to BC. In the 1920s, a positive RF is found as far south as $45^{\circ} \mathrm{N}$. North of $30^{\circ} \mathrm{N}$ the RF has decreased since 1980 while at southern latitudes the maximum RF occur in 2000 and 2010.

The total direct aerosol effect was $-0.51 \mathrm{~W} \mathrm{~m}^{-2}$ in 2000 and $-0.48 \mathrm{~W} \mathrm{~m}^{-2}$ in 2010 (Fig. 1d). The uncertainty in the total direct aerosol effect is better constrained than the uncertainty for each aerosol component. Myhre (2009) constrained the uncertainty for the direct aerosol effect to $-0.3 \pm 0.2 \mathrm{~W} \mathrm{~m}^{-2}$, by combining model results and observational based estimates. Our results for year 2000 are stronger than the best estimate from Myhre (2009), and in Fig. 1d we adopt the relative uncertainty range from Myhre (2009) giving a RF for the direct aerosol effect $-0.48 \pm 0.32 \mathrm{~W} \mathrm{~m}^{-2}$ in 2010.

\subsubsection{Indirect aerosol effects}

The calculated time series of RF for the cloud albedo effect are shown in Fig. 1c. The steepest strengthening occurs in the 1950s-1980s. In 2010 the cloud albedo effect is $-0.83 \mathrm{~W} \mathrm{~m}^{-2}$, slightly weaker than the best estimate of 
$-0.90 \mathrm{~W} \mathrm{~m}^{-2}$ provided by Isaksen et al. (2009). Isaksen et al. (2009) summarised the estimates from the literature and provided a $90 \%$ confidence interval ranging from -1.4 to $-0.3 \mathrm{~W} \mathrm{~m}^{-2}$. The zonal mean $\mathrm{RF}$ for the cloud albedo effect is shown in Fig. 3i, with a maximum at the equator and at $30^{\circ} \mathrm{N}$. North of $30^{\circ} \mathrm{N}$ the zonal mean RF has been constant since 1980.

The cloud lifetime effect was not considered as a RF in Forster et al. (2007). The RF concept in a strict sense does not allow for changes in the climatic state of the troposphere (Ramaswamy et al., 2001). However, the cloud lifetime effect is not a feedback through surface temperature change and it is a fast feedback occurring on the same time scale as the other RF mechanisms. Therefore we have included the cloud lifetime effect as a RF mechanism in this study. In this study detailed modelling of the cloud lifetime effect is not performed and we make a simple assumption of a linear relationship between the cloud albedo effect and the cloud lifetime effect. The time series for the cloud lifetime effect (Fig. 1c) are estimated by scaling the best estimate in Isaksen et al. (2009) of $-0.35 \mathrm{~W} \mathrm{~m}^{-2}$ with the cloud albedo effect time series, and has therefore a similar historical development as the cloud albedo effect.

For both the cloud albedo effect and cloud lifetime effect, the relative uncertainty range in Fig. 1d is taken from Isaksen et al. (2009). The largest uncertainty related to the radiative forcing mechanisms considered in this study is the uncertainty range for the cloud albedo effect and cloud lifetime effect (Fig. 1d).

\subsection{Surface albedo changes}

We find that the radiative forcing of surface albedo change due to land use has changed from $-0.03 \mathrm{~W} \mathrm{~m}^{-2}$ in 1850 to $-0.10 \mathrm{~W} \mathrm{~m}^{-2}$ in 2005 (Fig. 1c). Between 1970 and 1980 we find the strongest strengthening in global RF caused by extensive agricultural clearing in the $\mathrm{NH}$ during this period. The global radiative forcing peaks in $1990\left(-0.14 \mathrm{~W} \mathrm{~m}^{-2}\right)$, and has since weakened because of a reduced amount of agricultural land and regrowth in the NH. The effect of snow at $\mathrm{NH}$ mid-latitudes is very important, and has a strong influence on the global RF. Cropland areas in the SH during the industrial era have continuously increased during the whole period. Forster et al. (2007) gave a best estimate of RF due to land use change of $-0.2 \pm 0.2 \mathrm{~W} \mathrm{~m}^{-2}$. Previous studies also show that the forcing and climate effects of land use are very sensitive to the surface albedo value of cropland (Myhre and Myhre, 2003; Kvalevag et al., 2010). In Fig. 1d we assume the same RF in 2010 as in 2005 and adopt the same relative uncertainties as in Forster et al. (2007).

Radiative forcing time series of FFBF BC in snow is presented in Skeie et al. (2011). The RF in 2010 (assumed equal year 2000) of $0.016 \mathrm{~W} \mathrm{~m}^{-2}$ are shown in Fig. 1d with an uncertainty of a factor 4 , which includes recent results from other studies (Jacobson, 2004; Flanner et al., 2007; Koch et al., 2009; Rypdal et al., 2009) which are all lower than the best estimate of $0.1 \mathrm{~W} \mathrm{~m}^{-2}$ given in Forster et al. (2007). The snow albedo effect is negligible on a global scale compared to the other anthropogenic forcing agents (Fig. 1c and d). Our estimate includes only FFBF BC, and changes in boreal forest fires will give a RF but the historical emissions are highly uncertain. In Flanner et al. (2007) including the biomass burning $\mathrm{BC}$ in the RF calculations increased the RF from $0.043 \mathrm{~W} \mathrm{~m}^{-2}$ to $0.054 \mathrm{~W} \mathrm{~m}^{-2}$ and $0.049 \mathrm{~W} \mathrm{~m}^{-2}$ for a strong and a weak boreal forest fire year respectively. Including the effect of BB BC, the BC snow albedo effect would still be negligible on a global scale.

\subsection{Model-data comparison for total radiation}

In this section we evaluate the model simulations of downwelling solar radiation at the surface against observed records obtained from the GEBA dataset (Ohmura et al., 1989; Gilgen et al., 1998; Gilgen and Ohmura, 1999; Ohmura, 2009; Wild, 2009), which compiles the instrumentally measured energy fluxes at the surface worldwide. The GEBA dataset contains monthly-mean observations measured at approximately 2000 stations around the world (Fig. 12a) and consists of various components including total radiation, direct radiation, and indirect radiation. Only the total radiation records are used in our analysis because the numbers of records for direct and indirect radiation are limited. The lengths of records vary across the stations and many of them are affected by data breaks. Several records date back to the early 20th century - the longest record is available since 1923 at the station in Stockholm (Ohmura, 2009).

We geographically separate the world into the following seven regions: Europe, Japan, US and Canada, Asia (excluding Japan), South-West Pacific, South America, and Africa. For the analysis of Japan, we use the radiation data compiled by A. Ohmura (personal communication, 2010) that have been measured at 45 stations consistently since 1961 . A regional radiation data analysis is also shown in Ohmura (2009) but for more selected stations.

All the total radiation data available at the GEBA website have gone through initial screening processes prior to our analysis. In the GEBA dataset, each of the observational records is accompanied by a flag that indicates data quality records marked as bad quality by the GEBA quality control procedure (e.g. judged to be erroneous, suspected of being afflicted with error, and suspected of being not represented for a larger region) have been removed before our analysis. In addition, measurements obtained at stations located above $1000 \mathrm{~m}$ in altitude are not used in the analysis. As a result, the number of observational stations that actually entered into our analysis is reduced to 1555 .

For the purpose of comparison, both the model simulation results and the observations are expressed as annual mean values. Observations are expressed relative to the mean 

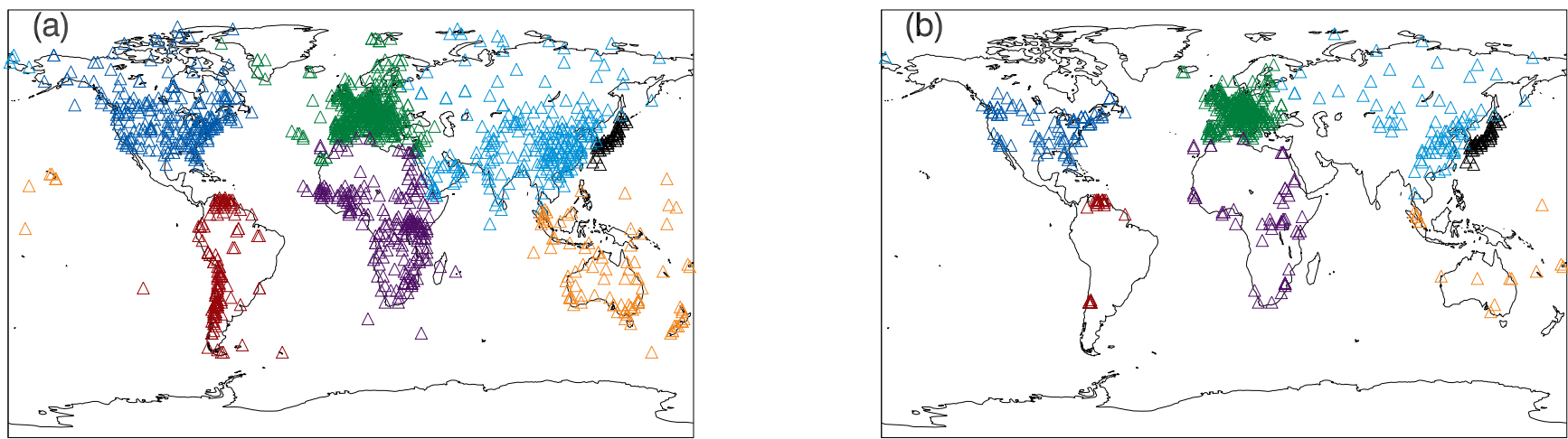

Fig. 12. Locations of the radiation measurement stations available in the GEBA dataset (a) and those used in our model-data comparison (b). The different colours indicate the different regions in Fig. 13.

during the 20-yr reference period specified for each region (i.e. rather than the absolute levels). Note that the reference periods are chosen for segments that have most abundant records and thus differ across the regions, depending on the data availability. Stations having no more than 10 annual-mean records during their 20-yr reference periods are disregarded in our analysis. Similar to the treatment for observations, model simulation results are also given as annualmean values (every $10 \mathrm{yr}$ ) and expressed as a departure from the reference period for the corresponding observations.

When there are multiple stations located within a single $2.8^{\circ} \times 2.8^{\circ}$ model grid, the records from such stations are averaged out to be compared with the simulation results of the particular model grid. After the data process described above, we have a total of 641 observational stations (Fig. 12b) that fall into 241 model grids. The data are not homogeneous both spatially and temporally (Figs. 12 and 13)the records over Europe, Japan, and Asia (excluding Japan) provide most useful basis for the evaluation of the model simulation results.

A model-based study by Kvalevåg and Myhre (2007) shows that each component contributes differently to determining the total radiation level at surface during the historical period. Our model simulation results are progressively presented for different components (direct aerosols, cloud albedo effect, tropospheric $\mathrm{O}_{3}$, and stratospheric $\mathrm{O}_{3}$ ) (Fig. 13). An increase in the aerosol content (scattering and absorbing components) leads to reduced downward radiative fluxes at the surface from both the direct and indirect aerosol effects. Likewise, an increase in the ozone in the troposphere reduces the fluxes at the surface. On the other hand, the observed reduction in stratospheric $\mathrm{O}_{3}$ will lead to increases in the downward solar radiative fluxes at the surface.

The model generally reproduces the observed global dimming and brightening trend (Wild, 2009). However, the trends are weaker in the model than in the observations (Fig. 13). Over Europe (Fig. 13a), the recovery from the dimming is earlier in the model simulation results by about a decade than indicated by the observations. As shown in Fig. $9 \mathrm{c}$ the sulphate amount has increased strongly over Europe between 1930 and 1980, with a sharp decrease thereafter. However, in our model simulations BC has been reduced between 1930 and 1990 leading to weaker dimming which has been the dominant trend in this period in the model results and observations. $\mathrm{BC}$ is much more efficient to reduce downward solar radiative fluxes at the surface than scattering aerosols (Ramanathan and Carmichael, 2008). Over Europe the indirect aerosol effect contributes only slightly to the dimming and brightening trends since the overall effect is of the order -1 to $-2 \mathrm{~W} \mathrm{~m}^{-2}$ and part of this was prior to 1930. The dimming and the later brightening effect for the direct aerosol effect is around $5 \mathrm{~W} \mathrm{~m}^{-2}$.

Over Japan, the model results reproduce the observed dimming trend well but do not capture the brightening trend that follows (Fig. 13b). The data are more limited over US and Canada (Fig. 13c) and observations show large interannual variation. The model shows only weak changes in the surface solar radiative fluxes with a weak brightening after 1980. Over Asia, excluding Japan (Fig. 13d), the observed rate of dimming in the latter half of the 20th century is underestimated by the model. There is some sign of recovery from the dimming in the observations after 2000, but the model simulations continue to show a decline in radiation till 2010. In the period between 1990 and 2000, the model shows a very weak dimming in the period where the observations have an indication of brightening. The observed total dimming in this region is about $10 \mathrm{~W} \mathrm{~m}^{-2}$, whereas the model has a dimming slightly stronger than $5 \mathrm{~W} \mathrm{~m}^{-2}$. Over Africa (Fig. 13e) the observed dimming is rather well reproduced by the model, even though there is an indication of a weak trend also in this region. In other regions, the observational records are either not long or dense enough to derive clear results (Fig. 13f, g).

The direct aerosol effect dominates the dimming and brightening trends in the model simulations. The contribution from ozone is weak and only over US and Canada the reduced ozone in the stratosphere contributes discernable to the 

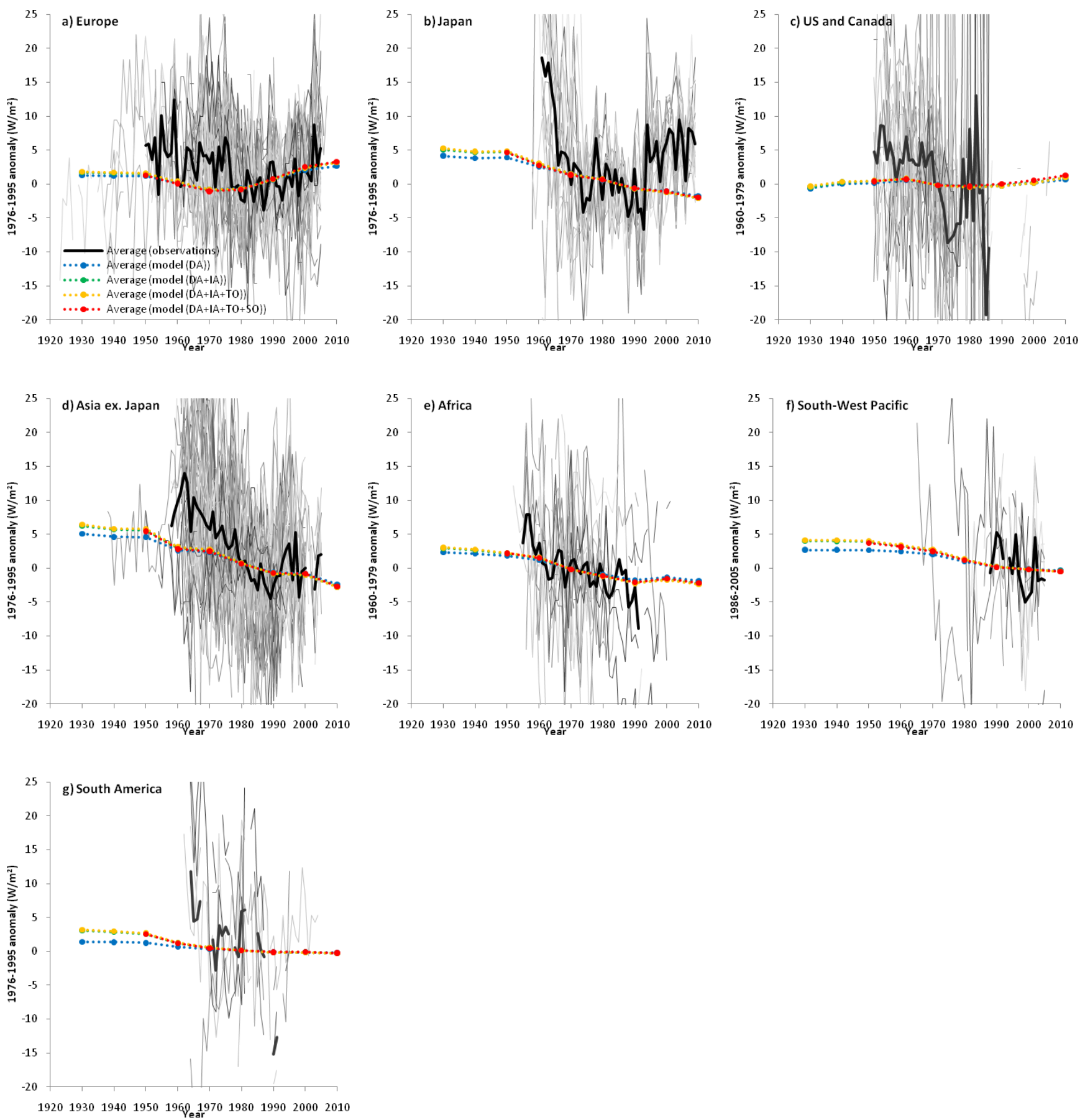

Fig. 13. Model-data comparisons for the total radiation at the surface over seven world regions. Observational records have been obtained from the GEBA dataset (Ohmura et al., 1989; Gilgen et al., 1998; Gilgen and Ohmura, 1999; Ohmura, 2009; Wild, 2009) and those for Japan from A. Ohmura (2 November 2010, personal communication). DA, IA, TO, and SO denote direct aerosols, indirect aerosols, tropospheric $\mathrm{O}_{3}$, and stratospheric $\mathrm{O}_{3}$, respectively. Note that observed annual-mean records are shown only when there are five or more records within the region in a particular year. 
brightening in the model results (Fig. 13c). To verify the contributions from different components, observational data separately for direct and diffuse radiation are useful (Ohmura, 2009) - however, such data are currently available only for a few recent decades and are not sufficient for our analysis.

Why is the dimming and brightening too weak in the model? We do not have an adequate answer to this, but several factors may contribute. We have included the direct aerosol effect and the cloud albedo effect, but other aerosol effects such as the cloud lifetime effect, semi-direct, and impacts of mixed phase and ice clouds may contribute to changes in the solar surface radiative fluxes. These effects would likely follow the general trend in the model results, but amplify the trends. Natural variability in clouds will strongly affect observations, whereas we have used constant cloud characteristics (except the cloud albedo effect) in the model simulations. Alpert et al. (2005) showed that the dimming trend was substantially stronger in highly populated regions compared to rural areas. With the short lifetime of aerosols and thus the inhomogeneous pattern in the aerosol content, the model with a resolution of $2.8^{\circ} \times 2.8^{\circ}$ may be unable to reproduce the observed trends which often are dominated by measurements in populated regions.

\section{Discussions}

In Fig. 1c the RF time series of all mechanisms considered are shown. Also added in Fig. 1c is the sum of the best estimates of the anthropogenic RF time series established in this study. The total anthropogenic RF reaches $1.4 \mathrm{~W} \mathrm{~m}^{-2}$ in 2010 and is weaker than the RF caused by LLGHGs, and also lower than the net anthropogenic $\mathrm{RF}$ (for 2005) of $1.6 \mathrm{~W} \mathrm{~m}^{-2}$ given in Forster et al. (2007). However, our estimate includes the cloud-lifetime effect. The net anthropogenic RF declined between 1940 and 1970 due to the rapid growth in sulphur emissions. There are large uncertainties in the cooling effects of aerosols (Fig. 1d) and probability distributions of the individual forcing mechanisms should be accounted for when summing the RF (Boucher and Haywood, 2001).

The concept of radiative forcing can to a first order represent global warming, since RF is related to the equilibrium response of global mean surface temperature through the climate sensitivity (e.g. Cess et al., 1989; Hansen et al., 1997; Forster et al., 2007). The period with declining total anthropogenic RF in Fig. 1c, is concurring with the period in between the two distinct phases when the global mean temperature increased, in the first half of the 20th century (19151945) and since 1975 (Trenberth et al., 2007). Running a two layer simple climate model (Berntsen and Fuglestvedt, 2008) with the total anthropogenic RF time series as given in Fig. 1c as input, gives an increase in temperature prior to 1942 and after 1972 and a decline in global mean temperature for the years in between. Some of the warming due to the increase in greenhouse gases is likely to have been offset due to aerosol cooling effects in the 2 nd half of the 20th century, keeping in mind the limitations of the RF concept that different forcing mechanisms may give different climate responses, the so called climate efficacy (Hansen et al., 2005), especially for components with inhomogeneous concentration changes.

The main focus in this article has been short lived forcing agents. For short lived components, the geographical distribution of the emissions and hence the distribution of the concentrations have changed over the 20th century. To investigate the relationship between burden changes and radiative forcing, the time series of the normalized RF for tropospheric $\mathrm{O}_{3}$ and the main aerosols are shown in Table 3. For the aerosols the normalized RF with respect to aerosol optical thickness at $550 \mathrm{~nm}$ (AOT 550nm) is also shown. For tropospheric $\mathrm{O}_{3}$, the normalized RF is relatively stable through the 20th century. The concentration of tropospheric $\mathrm{O}_{3}$ has changed (Fig. 6), but the shape of the zonal mean RF is similar over the century (Fig. 3a) explaining the relatively stable normalized RF. For the direct aerosol effects, the normalized RF of sulphate with respect to burden has weakened from $-227 \mathrm{~W} \mathrm{~g}^{-1}$ in 1900 to $-221 \mathrm{~W} \mathrm{~g}^{-1}$ in 2010 (Table 3). However, the normalized RF with respect to AOT $550 \mathrm{~nm}$ has slightly strengthened from 1900 to 2010 . The southward shift in the sulphate abundance from 1900 to 2010 has reduced the water uptake due to generally lower relative humidity and thus a weaker normalized RF with respect to burden, but the generally weaker reflectance (surface and clouds) has strengthens the normalized RF with respect to AOT. For BC, the normalized RF with respect to both burden and optical depth has increased with respectively $14 \%$ and $12 \%$ since 1900 (Table 3). For OC, the normalized RFs have slightly strengthened over the century.

Also the relationship between emission and burden has changed over the 20th century. A simple relationship between ozone burden and ozone precursor is the ozone production efficiency (e.g. Lamarque et al., 2005; Shindell et al., 2006a). The ozone production efficiency, the burden change (in Tg) divided by $\mathrm{NO}_{\mathrm{x}}$ emissions, does not include $\mathrm{CO}, \mathrm{CH}_{4}$ and other hydrocarbons important for ozone production. In this study the ozone production efficiency dropped between 1940 and 1980 by $31 \%$ (not shown), in the same period as $\mathrm{NO}_{\mathrm{x}}$ emissions increased rapidly at northern mid-latitudes, indicating that the fraction of the troposphere where ozone production was $\mathrm{NO}_{\mathrm{x}}$-limited decreased. Since 1980 the main growth in $\mathrm{NO}_{\mathrm{x}}$ emissions has occurred further south and ozone production efficiency has increased by $11 \%$ from 1980 to 2010, in accordance with Shindell et al. (2006a).

As discussed in the Sect. 3.4.1, the production efficiency of sulphate has decreased over the recent decades. For the carbonaceous aerosols burden divided by emissions, related to lifetime changes, increased by $15 \%$ since 1950 for FFBF BC and $12 \%$ for FFBF OC, due to the geographical shift in the emissions to regions were the wet scavenging is slower. For biomass burning aerosols the lifetimes were stable over 
Table 3. Normalized radiative forcing with respect to burden with unit $\mathrm{W} \mathrm{DU}^{-1}$ for ozone and $\mathrm{W} \mathrm{g}^{-1}$ for aerosols and normalized radiative forcing with respect to AOT $550 \mathrm{~nm}$ with unit $\mathrm{W} \mathrm{m}^{-2}$.

\begin{tabular}{llllllll}
\hline & Trop. $\mathrm{O}_{3}$ & $\mathrm{SO}_{4}$ & $\mathrm{SO}_{4}$ & $\mathrm{BC} \mathrm{FFBF}$ & $\mathrm{BC} \mathrm{FFBF}$ & OC FFBF & OC FFBF \\
\hline & $\left(\mathrm{W} \mathrm{DU}^{-1}\right)$ & $\left(\mathrm{W} \mathrm{g}^{-1}\right)$ & $\left(\mathrm{W} \mathrm{m}^{-2}\right)$ & $\left(\mathrm{W} \mathrm{g}^{-1}\right)$ & $\left(\mathrm{W} \mathrm{m}^{-2}\right)$ & $\left(\mathrm{W} \mathrm{g}^{-1}\right)$ & $\left(\mathrm{W} \mathrm{m}^{-2}\right)$ \\
1900 & 0.0385 & -227 & -19.1 & 2020 & 156 & -182 & -26.7 \\
1910 & 0.0380 & -226 & -19.2 & 2030 & 157 & -181 & -26.5 \\
1920 & 0.0385 & -227 & -19.2 & 2040 & 158 & -183 & -26.8 \\
1930 & 0.0392 & -226 & -19.3 & 2050 & 159 & -182 & -26.7 \\
1940 & 0.0396 & -225 & -19.2 & 2070 & 160 & -181 & -26.6 \\
1950 & 0.0390 & -226 & -19.5 & 2090 & 162 & -184 & -27.1 \\
1960 & 0.0386 & -223 & -19.6 & 2140 & 165 & -183 & -26.9 \\
1970 & 0.0381 & -221 & -19.7 & 2190 & 168 & -187 & -27.6 \\
1980 & 0.0379 & -221 & -19.8 & 2210 & 169 & -187 & -27.9 \\
1990 & 0.0380 & -221 & -19.6 & 2250 & 171 & -187 & -27.8 \\
2000 & 0.0380 & -223 & -19.9 & 2270 & 173 & -187 & -28.0 \\
2010 & 0.0382 & -221 & -19.6 & 2310 & 175 & -185 & -27.7 \\
\hline
\end{tabular}

the 20th century. To summarize, the relationship between emissions and RF, the fraction RF/emissions for sulphate $\left(\mathrm{W} \mathrm{m}^{-2} / \mathrm{Tg} \mathrm{S}\right.$ ) increased by $23 \%$ between 1950 and 2000. For FFBF OC and FFBF BC the fraction $\left(\mathrm{W} \mathrm{m}^{-2} \mathrm{Tg}^{-1}\right)$ increased by 12 and $27 \%$. Using a constant relationship between RF and emissions for short lived climate forcers based on present day RF, as is the case when global warming potentials (GWPs) are used, may overestimate the early and midcentury $\mathrm{RF}$ for $\mathrm{OC}, \mathrm{BC}$ and $\mathrm{SO}_{4}$.

For radiative forcing calculations of short lived components there are uncertainties related to the emissions, chemical reactions, transport, deposition processes and the radiative properties of the components. Radiative forcing is calculated from concentration changes from a base year, and especially for the short lived components there are uncertainties in the estimated contribution from anthropogenic activity to the pre-industrial concentrations, which must be considered in the RF uncertainty. In Fig. 1 the basis for the RF calculations is a pre-industrial atmosphere. To give an indication of the magnitude of the uncertainties in base year concentrations and to compare the RF results with studies using 1850 as a base year, we present the RF in 1850 relative to 1750. For tropospheric $\mathrm{O}_{3}$ the $\mathrm{RF}$ is $0.038 \mathrm{~W} \mathrm{~m}^{-2}$, which is $9 \%$ of total tropospheric $\mathrm{O}_{3} \mathrm{RF}$. For the aerosols, the RF in 1850 relative to 1750 is $-0.021 \mathrm{~W} \mathrm{~m}^{-2}$ or $3 \%$ for sulphate, $0.055 \mathrm{~W} \mathrm{~m}^{-2}$ or $11 \%$ for FFBF BC, $-0.031 \mathrm{~W} \mathrm{~m}^{-2}$ or $24 \%$ for FFBF OC, $-0.011 \mathrm{~W} \mathrm{~m}^{-2}$ or $24 \%$ for nitrate and $-0.021 \mathrm{~W} \mathrm{~m}^{-2}$ or $23 \%$ for SOA. For biomass burning aerosols, the RF in 1850 relative to 1750 is $-0.054 \mathrm{~W} \mathrm{~m}^{-2}$ or $77 \%$. For the total direct aerosol effect the RF increased by $0.081 \mathrm{~W} \mathrm{~m}^{-2}$ using 1850 as a base year instead of 1750 . That is $17 \%$ of the total direct aerosol effect which is within the uncertainty range presented in Fig. 1d.
There are large uncertainties in the historical biomass burning emission data as discussed in the results section. A large increase in the biomass burning emissions from 1750 to 1850 is likely (Marlon et al., 2008; Wang et al., 2010), and hence a large difference in the radiative forcing estimate of the biomass burning aerosol direct effect is expected. The biomass burning emissions do not only influence the direct aerosol effect of biomass burning aerosols, but influence the oxidation capacity as well. In year $2000,17 \%$ of the $\mathrm{NO}_{\mathrm{x}}$ emissions and $43 \%$ of the $\mathrm{CO}$ emissions in Lamarque et al. (2010) is from biomass burning. As pointed out in Lamarque et al. (2010) the uncertainties in biomass burning emissions are large, not only for the historical emissions but also for current emissions from biomass burning.

For other emission sectors, there are uncertainties in the emissions as well. Uncertainties for the emission inventory used was not provided by Lamarque et al. (2010). The uncertainties in present day inventories for BC FFBC and FFBF OC are about a factor of 2 (Bond et al., 2004; Bond et al., 2007) and there are uncertainties in the rate of change of the emissions and the uncertainties differ in different regions, but are not quantified by Bond et al. (2007). Smith et al. (2011) found that uncertainties in the regional emissions of $\mathrm{SO}_{2}$ are far higher than the uncertainties in the global emissions. The $5-95 \%$ confidence interval for the global emissions is $9 \%$ of the best estimate in 2000 and range between $16 \%$ and $7 \%$ between 1850 and 2005. The regional uncertainties in the emissions in Former Soviet Union were $20 \%$ in 1990 and $30 \%$ in China for the year 2000. A formal error propagation for the RF time series of short lived components including the uncertainties in the rate of change and spatial distribution of the emissions is not performed in this study or other published studies. The error estimates for all mechanisms (Fig. 1d) are therefore based on spread found in previous studies. 
There is a lack of observations of short lived components, in particular back in time. The model generally reproduces the global dimming and brightening trends, however the modelled trends are weaker than observed. From the few ozone observations considered, the modelled trend in tropospheric $\mathrm{O}_{3}$ is smaller than the observed trend prior to 1990. This was also found by Lamarque et al. (2010) who related it to limitation of the emission data. We also found that the $\mathrm{OH}$ concentrations did not decrease as fast as what is inferred from observations. For a large part of the world, the observations are very limited, and therefore it is difficult to validate the modelled trends. Also worth noting when comparing modelling results of short lived components with observations, is that constant meteorology is used in this study. This makes discrepancies in the comparison, since changes in flow directions relative to the measurement site and the occurrence of stagnant air situations influence the observed concentrations. In addition, there is a large interannual variability in biomass burning emissions, and in this study the emissions represent a decadal mean. Hess and Mahowald (2009) investigated the role of meteorology (including lightning induced $\mathrm{NO}_{\mathrm{x}}$ emissions) on chemical components in model simulations for the period 1979 to 1999 . They found that variability for global values were generally between 0.5 to $1 \%$, while locally the variability was larger. Since we in this study focus on global radiative forcing values and look at differences relative to pre-industrial times, using meteorological data for one year does not increase the total uncertainty significantly.

There are other proposed RF mechanisms that are not included in this study due to large uncertainties and lack of scientific knowledge. The semi-direct effect (Hansen et al., 1997), the evaporation of clouds and inhibition of formation of clouds due to absorbing aerosols, is poorly understood and even the sign of the forcing is uncertain. Isaksen et al. (2009) gave a range for the semi-direct effect from -0.25 to $+0.50 \mathrm{~W} \mathrm{~m}^{-2}$. The information used for establishing RF time series for the indirect aerosol effects considered in this study is based on aerosol effects on liquid water clouds. Aerosol indirect effects on mixed-phase clouds are not considered, however a recent study by Storelvmo et al. (2011) found that the cloud albedo effect counteracts the cloud lifetime effect of mixed-phase clouds and that the net radiative effects are small. There are large uncertainties for the indirect aerosol effects in pure ice clouds, which are possibly of great importance (Penner et al., 2009). In this work, the aviation induced radiative forcing of linear contrails is not included. The RF of this mechanism of $0.01(+0.02$, $-0.007) \mathrm{W} \mathrm{m}^{-2}$ given in Forster et al. (2007), constituting only $0.5 \%$ of the RF from $\mathrm{CO}_{2}$, is considered to be negligible. A possible larger climate effect from aviation, however one which is not in this study, is induced cirrus clouds, the extend of which is highly uncertain (Penner et al., 1999; Burkhardt and Karcher, 2011).

\section{Conclusions}

We have presented radiative forcing time series of what are currently believed to be the main anthropogenic components. The concentration changes for the short lived components are calculated using OsloCTM2 and the emission inventories from Lamarque et al. (2010) extended back to 1750 and forward to 2010. Radiative forcing time series are calculated based on the concentration changes using a radiative transfer model. The RF of tropospheric $\mathrm{O}_{3}$ in 2010 was $0.44 \pm 0.13 \mathrm{~W} \mathrm{~m}^{-2}$, with the largest rate of change between 1960 and 1980. For the total direct aerosol effect the RF in 2010 was $-0.48 \pm 0.32 \mathrm{~W} \mathrm{~m}^{-2}$. The direct aerosol effect strengthened rapidly between 1950 and 1960 and has been stable and slightly weakening over the last decades. The main anthropogenic forcing is the long lived greenhouse gases with RF in 2010 of $2.83 \pm 0.28 \mathrm{~W} \mathrm{~m}^{-2}$. Looking at the historical time period, and accounting for all well established RF mechanisms, including the cloud lifetime effect, we find that the total anthropogenic RF declined between the 1950s and the 1970s, although the LLGHG RF increased. In 2010 the total anthropogenic RF was $1.4 \mathrm{~W} \mathrm{~m}^{-2}$. The main sources of uncertainties are in the modelling of the indirect aerosol effects as well as in the emissions inventory for the aerosols and aerosol precursors. There is a lack of historical observational data for short lived components which could be used to validate the model results. Therefore more model studies should be preformed and several consistent emission inventories considering tropospheric $\mathrm{O}_{3}$ and aerosol precursors would be useful, especially for biomass burning emission data. To understand recent climate change and to constrain climate sensitivity based on observed air temperatures and ocean heat content, not only RF for present day relative to pre-industrial times and its uncertainty are important, but also the temporal path of the radiative forcing over the industrial era.

Acknowledgements. The authors thank those providing observational data for the GAW, EMEP and IMPROVE network and the German Meteorological Service/Hohenpeissenberg Meteorological Observatory, J. R. McConnell and P. Bousquet for data contribution. We thank D. Stevenson for providing the script for Fig. 5. Thanks also to N. Ramankutty for making the updated and extended data set on land use available. We acknowledge the European Commission for Information and Communication Technologies and the Institute for Climate and Atmospheric Sciences at ETH Zurich for supporting and providing the GEBA database. The radiation data of Japan made available through the support of the Radiation Section of Japan Meteorological Agency were compiled and kindly provided by A. Ohmura at ETH Zurich. This research was supported by the Norwegian Research Council under the project "Constraining total feedback of the climate system by observations and models" and "Climate and health impacts of short lived atmospheric components". K. Tanaka is partly supported by a Marie Curie Intra European Fellowship within the 7th European Community Framework Programme (Proposal No 255568 under FP7-PEOPLE-2009-IEF). 
Edited by: Q. Fu

\section{References}

Albrecht, B. A.: Aerosols, cloud microphysics, and fractional cloudiness, Science, 245, 1227-1230, 1989.

Alpert, P., Kishcha, P., Kaufman, Y. J., and Schwarzbard, R.: Global dimming or local dimming?: Effect of urbanization on sunlight availability, Geophys. Res. Lett., 32, L17802, doi:10.1029/2005g1023320, 2005.

Bauer, S. E., Koch, D., Unger, N., Metzger, S. M., Shindell, D. T., and Streets, D. G.: Nitrate aerosols today and in 2030: a global simulation including aerosols and tropospheric ozone, Atmos. Chem. Phys., 7, 5043-5059, doi:10.5194/acp-7-5043-2007, 2007.

Berglen, T. F., Berntsen, T. K., Isaksen, I. S. A., and Sundet, J. K.: A global model of the coupled sulfur/oxidant chemistry in the troposphere: The sulfur cycle, J. Geophys. Res., 109, D19310, doi:10.1029/2003jd003948, 2004.

Berglen, T. F., Myhre, G., Isaksen, I. S. A., Vestreng, V., and Smith, S. J.: Sulphate trends in Europe: are we able to model the recent observed decrease ?, Tellus B, 59, 773-786, doi:10.1111/j.16000889.2007.00289.x, 2007.

Berntsen, T. and Fuglestvedt, J.: Global temperature responses to current emissions from the transport sectors, PNAS, 105, 1915419159, doi:10.1073/pnas.0804844105, 2008.

Berntsen, T. K. and Isaksen, I. S. A.: A global three-dimensional chemical transport model for the troposphere .1. Model description and CO and ozone results, J. Geophys. Res., 102, 2123921280, 1997.

Berntsen, T. K., Myhre, G., Stordal, F., and Isaksen, I. S. A.: Time evolution of tropospheric ozone and its radiative forcing, J. Geophys. Res., 105, 8915-8930, 2000.

Berntsen, T., Fuglestvedt, J., Myhre, G., Stordal, F., and Berglen, T. F.: Abatement of greenhouse gases: Does location matter?, Clim. Change, 74, 377-411, 2006.

Betts, R. A.: Offset of the potential carbon sink from boreal forestation by decreases in surface albedo, Nature, 408, 187-190, 2000.

Bond, T. C., Streets, D. G., Yarber, K. F., Nelson, S. M., Woo, J. H., and Klimont, Z.: A technology-based global inventory of black and organic carbon emissions from combustion, J. Geophys. Res., 109, D14203, doi:10.1029/2003JD003697, 2004.

Bond, T. C., Bhardwaj, E., Dong, R., Jogani, R., Jung, S. K., Roden, C., Streets, D. G., and Trautmann, N. M.: Historical emissions of black and organic carbon aerosol from energy-related combustion, 1850-2000, Global Biogeochem. Cy., 21, GB2018, doi:10.1029/2006gb002840, 2007.

Boucher, O. and Haywood, J.: On summing the components of radiative forcing of climate change, Clim. Dynam., 18, 297-302, doi:10.1007/s003820100185, 2001.

Boucher, O. and Pham, M.: History of sulfate aerosol radiative forcings, Geophys. Res. Lett., 29, 1308, doi:10.1029/2001g1014048, 2002.

Bousquet, P., Hauglustaine, D. A., Peylin, P., Carouge, C., and Ciais, P.: Two decades of $\mathrm{OH}$ variability as inferred by an inversion of atmospheric transport and chemistry of methyl chloroform, Atmos. Chem. Phys., 5, 2635-2656, doi:10.5194/acp-52635-2005, 2005.
Brasseur, G. P., Schultz, M., Granier, C., Saunois, M., Diehl, T., Botzet, M., Roeckner, E., and Walters, S.: Impact of Climate Change on the Future Chemical Composition of the Global Troposphere, J. Clim., 19, 3932-3951, doi:doi:10.1175/JCLI3832.1, 2006.

Briegleb, B. P.: Delta-Eddington Approximation for SolarRadiation in the Ncar Community Climate Model, J. Geophys. Res., 97, 7603-7612, 1992.

Burkhardt, U. and Karcher, B.: Global radiative forcing from contrail cirrus, Nature Clim. Change, 1, 54-58, 2011.

Cess, R. D., Potter, G. L., Blanchet, J. P., Boer, G. J., Ghan, S. J., Kiehl, J. T., Le Treut, H., Li, Z.-X., Liang, X.-Z., Mitchell, J. F. B., Morcrette, J.-J., Randall, D. A., Riches, M. R., Roeckner, E., Schlese, U., Slingo, A., Taylor, K. E., Washington, W. M., Wetherald, R. T., and Yagai, I.: Interpretation of Cloud-Climate Feedback as Produced by 14 Atmospheric General Circulation Models, Science, 245, 513-516, doi:10.1126/science.245.4917.513, 1989.

Chung, S. H. and Seinfeld, J. H.: Global distribution and climate forcing of carbonaceous aerosols, J. Geophys. Res., 107, 4407, doi:10.1029/2001jd001397, 2002.

Cionni, I., Eyring, V., Lamarque, J. F., Randel, W. J., Stevenson, D. S., Wu, F., Bodeker, G. E., Shepherd, T. G., Shindell, D. T., and Waugh, D. W.: Ozone database in support of CMIP5 simulations: results and corresponding radiative forcing, Atmos. Chem. Phys., 11, 11267-11292, doi:10.5194/acp-11-11267-2011, 2011.

Cooper, O. R., Parrish, D. D., Stohl, A., Trainer, M., Nedelec, P., Thouret, V., Cammas, J. P., Oltmans, S. J., Johnson, B. J., Tarasick, D., Leblanc, T., McDermid, I. S., Jaffe, D., Gao, R., Stith, J., Ryerson, T., Aikin, K., Campos, T., Weinheimer, A., and Avery, M. A.: Increasing springtime ozone mixing ratios in the free troposphere over western North America, Nature, 463, 344-348, doi:10.1038/nature08708, 2010.

Dalsøren, S. B., Eide, M. S., Myhre, G., Endresen, Ø., Isaksen, I. S. A., and Fuglestvedt, J. S.: Impacts of the Large Increase in International Ship Traffic 2000-2007 on Tropospheric Ozone and Methane, Environ. Sci. Technol., 44, 2482-2489, doi:10.1021/es902628e, 2010.

Daniel, J. S. and Velders, G. J. M.: Halocarbon Scenarios, Ozone Depletion Potentials, and Global Warming Potentials, in: Scientific Assessment of Ozone Depletion: 2006, Global Ozone Research and Monitoring Project-Report No. 50, 572, 2007.

Del Genio, A. D., Yao, M. S., and Jonas, J.: Will moist convection be stronger in a warmer climate?, Geophys. Res. Lett., 34, L16703, doi:10.1029/2007g1030525, 2007.

Dentener, F., Drevet, J., Lamarque, J. F., Bey, I., Eickhout, B., Fiore, A. M., Hauglustaine, D., Horowitz, L. W., Krol, M., Kulshrestha, U. C., Lawrence, M., Galy-Lacaux, C., Rast, S., Shindell, D., Stevenson, D., Van Noije, T., Atherton, C., Bell, N., Bergman, D., Butler, T., Cofala, J., Collins, B., Doherty, R., Ellingsen, K., Galloway, J., Gauss, M., Montanaro, V., Muller, J. F., Pitari, G., Rodriguez, J., Sanderson, M., Solmon, F., Strahan, S., Schultz, M., Sudo, K., Szopa, S., and Wild, O.: Nitrogen and sulfur deposition on regional and global scales: A multimodel evaluation, Global Biogeochem. Cy., 20, GB4003, doi:10.1029/2005GB002672, 2006a.

Dentener, F., Kinne, S., Bond, T., Boucher, O., Cofala, J., Generoso, S., Ginoux, P., Gong, S., Hoelzemann, J. J., Ito, A., Marelli, L., Penner, J. E., Putaud, J. P., Textor, C., Schulz, M., van der Werf, 
G. R., and Wilson, J.: Emissions of primary aerosol and precursor gases in the years 2000 and 1750 prescribed data-sets for AeroCom, Atmos. Chem. Phys., 6, 4321-4344, doi:10.5194/acp6-4321-2006, $2006 \mathrm{~b}$.

Derwent, R. G., Simmonds, P. G., Manning, A. J., and Spain, T. G.: Trends over a 20-year period from 1987 to 2007 in surface ozone at the atmospheric research station, Mace Head, Ireland, Atmos. Environ., 41, 9091-9098, doi:10.1016/j.atmosenv.2007.08.008, 2007.

Douglass, A., Fioletov, V., Authors:, L., Godin-Beekmann, S., Müller, R., Stolarski, R. S., Webb, A., Arola, A., Burkholder, J. B., Burrows, J. P., Chipperfield, M. P., Cordero, R., David, C., Outer, P. N. d., Diaz, S. B., Flynn, L. E., Hegglin, M., Herman, J. R., Huck, P., Janjai, S., Jánosi, I. M., Krzycin, J. W., Liu, Y., Logan, J., Matthes, K., McKenzie, R. L., Muthama, N. J., Petropavlovskikh, I., Pitts, M., Ramachandran, S., Rex, M., Salawitch, R. J., Sinnhuber, B.-M., Staehelin, J., Strahan, S., Tourpali, K., Valverde-Canossa, J., and Vigouroux, C.: Chapter 2: Stratospheric Ozone and Surface Ultraviolet Radiation, in: WMO/UNEP Scientific Assessments of Ozone Depletion, 2011.

Etheridge, D. M., Steele, L. P., Langenfelds, R. L., Francey, R. J., Barnola, J. M., and Morgan, V. I.: Natural and anthropogenic changes in atmospheric $\mathrm{CO} 2$ over the last 1000 years from air in Antarctic ice and firn, J. Geophys. Res., 101, 4115-4128, 1996.

Etheridge, D. M., Steele, L. P., Francey, R. J., and Langenfelds, R. L.: Atmospheric methane between $1000 \mathrm{AD}$ and present: Evidence of anthropogenic emissions and climatic variability, J. Geophys. Res., 103, 15979-15993, 1998.

Fiore, A. M., Dentener, F. J., Wild, O., Cuvelier, C., Schultz, M. G., Hess, P., Textor, C., Schulz, M., Doherty, R. M., Horowitz, L. W., MacKenzie, I. A., Sanderson, M. G., Shindell, D. T., Stevenson, D. S., Szopa, S., Van Dingenen, R., Zeng, G., Atherton, C., Bergmann, D., Bey, I., Carmichael, G., Collins, W. J., Duncan, B. N., Faluvegi, G., Folberth, G., Gauss, M., Gong, S., Hauglustaine, D., Holloway, T., Isaksen, I. S. A., Jacob, D. J., Jonson, J. E., Kaminski, J. W., Keating, T. J., Lupu, A., Marmer, E., Montanaro, V., Park, R. J., Pitari, G., Pringle, K. J., Pyle, J. A., Schroeder, S., Vivanco, M. G., Wind, P., Wojcik, G., Wu, S., and Zuber, A.: Multimodel estimates of intercontinental sourcereceptor relationships for ozone pollution, J. Geophys. Res., 114, D04301, doi:10.1029/2008jd010816, 2009.

Flanner, M. G., Zender, C. S., Randerson, J. T., and Rasch, P. J.: Present-day climate forcing and response from black carbon in snow, J. Geophys. Res., 112, D11202, doi:10.1029/2006JD008003, 2007.

Forster, P., Ramaswamy, V., Artaxo, P., Berntsen, T., Betts, R., Fahey, D. W., Haywood, J., Lean, J., Lowe, D. C., Myhre, G., Nganga, J., Prinn, R., Raga, G., Schulz, M., and Dorland, R. V.: Changes in Atmospheric Constituents and in Radiative Forcing., in: Climate Change 2007: The Physical Science Basis. Contribution of Working Group I to the Fourth Assessment Report of the Intergovernmental Panel on Climate Change, edited by: Solomon, S., Qin, D., Manning, M., Chen, Z., Marquis, M., Averyt, K. B., Tignor, M., and Miller, H. L., Cambridge Univ. Press, Cambridge and New York, USA, 2007.

Forster, P. M., Thompson, D. W. J., Baldwin, M. P., Chipperfield, M. P., Dameris, M., Haigh, J. D., Karoly, D. J., Kushner, P. J., Randel, W. J., Rosenlof, K. H., Seidel, D. J., and Solomon, S.: Chapter 4 Stratospheric Changes and Climate, in: WMO/UNEP
Scientific Assessments of Ozone Depletion, 2011.

Forster, P. M. D. and Shine, K. P.: Radiative forcing and temperature trends from stratospheric ozone changes, J. Geophys. Res., 102, 10841-10855, 1997.

Gao, F., Schaaf, C. B., Strahler, A. H., Roesch, A., Lucht, W., and Dickinson, R.: MODIS bidirectional reflectance distribution function and albedo Climate Modeling Grid products and the variability of albedo for major global vegetation types, J. Geophys. Res., 110, D01104, doi:10.1029/2004jd005190, 2005.

Gauss, M., Myhre, G., Isaksen, I. S. A., Grewe, V., Pitari, G., Wild, O., Collins, W. J., Dentener, F. J., Ellingsen, K., Gohar, L. K., Hauglustaine, D. A., Iachetti, D., Lamarque, J. F., Mancini, E., Mickley, L. J., Prather, M. J., Pyle, J. A., Sanderson, M. G., Shine, K. P., Stevenson, D. S., Sudo, K., Szopa, S., and Zeng, G.: Radiative forcing since preindustrial times due to ozone change in the troposphere and the lower stratosphere, Atmos. Chem. Phys., 6, 575-599, doi:10.5194/acp-6-575-2006, 2006.

Gilgen, H. and Ohmura, A.: The Global Energy Balance Archive, B. Am. Meteorol. Soc., 80, 831-850, doi:10.1175/15200477(1999)080<0831:TGEBA > 2.0.CO;2, 1999.

Gilgen, H., Wild, M., and Ohmura, A.: Means and trends of shortwave irradiance at the surface estimated from global energy balance archive data, J. Clim., 11, 2042-2061, 1998.

Goldewijk, K. K.: Three Centuries of Global Population Growth: A Spatial Referenced Population (Density) Database for 1700-2000, Population \& Environment, 26, 343-367, doi:10.1007/s11111-005-3346-7, 2005.

Granier, C., Lamarque, J. F., Mieville, A., Muller, J. F., Olivier, J., Orlando, J., Peters, J., Petron, G., Tyndall, G., and S. W.: POET, a database of surface emissions of ozone precursors, available on internet at http://www.aero.jussieu.fr/projet/ACCENT/POET.php 2005.

Grini, A., Myhre, G., Sundet, J. K., and Isaksen, I. S. A.: Modeling the annual cycle of sea salt in the global 3D model Oslo CTM2: Concentrations, fluxes, and radiative impact, J. Clim., 15, 17171730, 2002.

Grini, A., Myhre, G., Zender, C. S., and Isaksen, I. S. A.: Model simulations of dust sources and transport in the global atmosphere: Effects of soil erodibility and wind speed variability, J. Geophys. Res., 110, D02205, doi:10.1029/2004JD005037, 2005.

Hansen, J. and Sato, M.: Greenhouse gas growth rates, Proc. Natl. Acad. Sci. USA, 101, 16109-16114, doi:10.1073/pnas.0406982101, 2004.

Hansen, J., Sato, M., and Ruedy, R.: Radiative forcing and climate response, J. Geophys. Res., 102, 6831-6864, 1997.

Hansen, J., Sato, M., Ruedy, R., Nazarenko, L., Lacis, A., Schmidt, G. A., Russell, G., Aleinov, I., Bauer, M., Bauer, S., Bell, N., Cairns, B., Canuto, V., Chandler, M., Cheng, Y., Del Genio, A., Faluvegi, G., Fleming, E., Friend, A., Hall, T., Jackman, C., Kelley, M., Kiang, N., Koch, D., Lean, J., Lerner, J., Lo, K., Menon, S., Miller, R., Minnis, P., Novakov, T., Oinas, V., Perlwitz, J., Rind, D., Romanou, A., Shindell, D., Stone, P., Sun, S., Tausnev, N., Thresher, D., Wielicki, B., Wong, T., Yao, M., and Zhang, S.: Efficacy of climate forcings, J. Geophys. Res., 110, D18104, doi:10.1029/2005JD005776, 2005.

Hansen, J., Sato, M., Ruedy, R., Kharecha, P., Lacis, A., Miller, R., Nazarenko, L., Lo, K., Schmidt, G., Russell, G., Aleinov, I., Bauer, S., Baum, E., Cairns, B., Canuto, V., Chandler, M., Cheng, Y., Cohen, A., Del Genio, A., Faluvegi, G., Fleming, E., 
Friend, A., Hall, T., Jackman, C., Jonas, J., Kelley, M., Kiang, N., Koch, D., Labow, G., Lerner, J., Menon, S., Novakov, T., Oinas, V., Perlwitz, J., Perlwitz, J., Rind, D., Romanou, A., Schmunk, R., Shindell, D., Stone, P., Sun, S., Streets, D., Tausnev, N., Thresher, D., Unger, N., Yao, M., and Zhang, S.: Climate simulations for 1880-2003 with GISS modelE, Clim. Dynam., 29, 661-696, doi:10.1007/s00382-007-0255-8, 2007.

Hansen, J. E., Sato, M., Lacis, A., Ruedy, R., Tegen, I., and Matthews, E.: Climate forcings in the Industrial era, Proc. Natl. Acad. Sci. USA, 95, 12753-12758, 1998.

Hauglustaine, D. A., Lathière, J., Szopa, S., and Folberth, G. A.: Future tropospheric ozone simulated with a climatechemistry-biosphere model, Geophys. Res. Lett., 32, L24807, doi:10.1029/2005g1024031, 2005.

Hess, P. and Mahowald, N.: Interannual variability in hindcasts of atmospheric chemistry: the role of meteorology, Atmos. Chem. Phys., 9, 5261-5280, doi:10.5194/acp-9-5261-2009, 2009.

Hou, Y. T., Moorthi, S., and Campana, K.: Parameterization of solar radiation transfer in the NCEP models, NCEP office note, 441, 46 pp., 2002.

Hoyle, C. R., Berntsen, T., Myhre, G., and Isaksen, I. S. A.: Secondary organic aerosol in the global aerosol - chemical transport model Oslo CTM2, Atmos. Chem. Phys., 7, 5675-5694, doi:10.5194/acp-7-5675-2007, 2007.

Hoyle, C. R., Myhre, G., Berntsen, T. K., and Isaksen, I. S. A.: Anthropogenic influence on SOA and the resulting radiative forcing, Atmos. Chem. Phys., 9, 2715-2728, doi:10.5194/acp-9-27152009, 2009.

Hoyle, C. R., Boy, M., Donahue, N. M., Fry, J. L., Glasius, M., Guenther, A., Hallar, A. G., Huff Hartz, K., Petters, M. D., Petäjä, T., Rosenoern, T., and Sullivan, A. P.: A review of the anthropogenic influence on biogenic secondary organic aerosol, Atmos. Chem. Phys., 11, 321-343, doi:10.5194/acp-11-321-2011, 2011a.

Hoyle, C. R., Marécal, V., Russo, M. R., Allen, G., Arteta, J., Chemel, C., Chipperfield, M. P., D’ Amato, F., Dessens, O., Feng, W., Hamilton, J. F., Harris, N. R. P., Hosking, J. S., Lewis, A. C., Morgenstern, O., Peter, T., Pyle, J. A., Reddmann, T., Richards, N. A. D., Telford, P. J., Tian, W., Viciani, S., Volz-Thomas, A., Wild, O., Yang, X., and Zeng, G.: Representation of tropical deep convection in atmospheric models - Part 2: Tracer transport, Atmos. Chem. Phys., 11, 8103-8131, doi:10.5194/acp-118103-2011, 2011b.

Isaksen, I. S. A., Zerefos, C., Kourtidis, K., Meleti, C., Dalsoren, S. B., Sundet, J. K., Grini, A., Zanis, P., and Balis, D.: Tropospheric ozone changes at unpolluted and semipolluted regions induced by stratospheric ozone changes, J. Geophys. Res., 110, D02302, doi:10.1029/2004jd004618, 2005.

Isaksen, I. S. A., Granier, C., Myhre, G., Berntsen, T. K., Dalsoren, S. B., Gauss, M., Klimont, Z., Benestad, R., Bousquet, P., Collins, W., Cox, T., Eyring, V., Fowler, D., Fuzzi, S., Jockel, P., Laj, P., Lohmann, U., Maione, M., Monks, P., Prevot, A. S. H., Raes, F., Richter, A., Rognerud, B., Schulz, M., Shindell, D., Stevenson, D. S., Storelvmo, T., Wang, W. C., van Weele, M., Wild, M., and Wuebbles, D.: Atmospheric composition change: Climate-Chemistry interactions, Atmos. Environ., 43, 5138-5192, doi:10.1016/j.atmosenv.2009.08.003, 2009.

Ito, A. and Penner, J. E.: Historical emissions of carbonaceous aerosols from biomass and fossil fuel burning for the period 1870-2000, Global Biogeochem. Cy., 19, GB2028, doi:10.1029/2004GB002374, 2005.

Jacobson, M. Z.: Climate response of fossil fuel and biofuel soot, accounting for soot's feedback to snow and sea ice albedo and emissivity, J. Geophys. Res., 109, D21201, doi:10.1029/2004jd004945, 2004.

Kinne, S., Schulz, M., Textor, C., Guibert, S., Balkanski, Y., Bauer, S. E., Berntsen, T., Berglen, T. F., Boucher, O., Chin, M., Collins, W., Dentener, F., Diehl, T., Easter, R., Feichter, J., Fillmore, D., Ghan, S., Ginoux, P., Gong, S., Grini, A., Hendricks, J. E., Herzog, M., Horowitz, L., Isaksen, L., Iversen, T., Kirkavag, A., Kloster, S., Koch, D., Kristjansson, J. E., Krol, M., Lauer, A., Lamarque, J. F., Lesins, G., Liu, X., Lohmann, U., Montanaro, V., Myhre, G., Penner, J. E., Pitari, G., Reddy, S., Seland, O., Stier, P., Takemura, T., and Tie, X.: An AeroCom initial assessment - optical properties in aerosol component modules of global models, Atmos. Chem. Phys., 6, 1815-1834, doi:10.5194/acp-6-1815-2006, 2006.

Knutti, R. and Hegerl, G. C.: The equilibrium sensitivity of the Earth's temperature to radiation changes, Nat. Geosci., 1, 735743, doi:10.1038/ngeo337, 2008.

Koch, D., Menon, S., Del Genio, A., Ruedy, R., Alienov, I., and Schmidt, G. A.: Distinguishing Aerosol Impacts on Climate over the Past Century, J. Clim., 22, 2659-2677, doi:10.1175/2008jcli2573.1, 2009.

Kvalevåg, M. M. and Myhre, G.: Human impact on direct and diffuse solar radiation during the industrial era, J. Clim., 20, 4874 4883, 2007.

Kvalevåg, M. M., Myhre, G., Bonan, G., and Levis, S.: Anthropogenic land cover changes in a GCM with surface albedo changes based on MODIS data, Int. J. Clim., 30, 2105-2117, doi:10.1002/Joc.2012, 2010.

Lamarque, J. F., Hess, P., Emmons, L., Buja, L., Washington, W., and Granier, C.: Tropospheric ozone evolution between 1890 and 1990, J. Geophys. Res., 110, D08304, doi:10.1029/2004jd005537, 2005.

Lamarque, J. F., Bond, T. C., Eyring, V., Granier, C., Heil, A., Klimont, Z., Lee, D., Liousse, C., Mieville, A., Owen, B., Schultz, M. G., Shindell, D., Smith, S. J., Stehfest, E., Van Aardenne, J., Cooper, O. R., Kainuma, M., Mahowald, N., McConnell, J. R., Naik, V., Riahi, K., and van Vuuren, D. P.: Historical (1850-2000) gridded anthropogenic and biomass burning emissions of reactive gases and aerosols: methodology and application, Atmos. Chem. Phys., 10, 7017-7039, doi:10.5194/acp10-7017-2010, 2010.

Lelieveld, J., van Aardenne, J., Fischer, H., de Reus, M., Williams, J., and Winkler, P.: Increasing ozone over the Atlantic Ocean, Science, 304, 1483-1487, doi:10.1126/science.1096777, 2004.

Liao, H., and Seinfeld, J. H.: Global impacts of gas-phase chemistry-aerosol interactions on direct radiative forcing by anthropogenic aerosols and ozone, J. Geophys. Res., 110, D18208, doi:10.1029/2005jd005907, 2005.

Logan, J. A.: Trends in the vertical-distribution of ozone - an analysis of ozonesonde data, J. Geophys. Res., 99, 25553-25585, 1994.

Logan, J. A.: An analysis of ozonesonde data for the troposphere: Recommendations for testing 3-D models and development of a gridded climatology for tropospheric ozone, J. Geophys. Res., 104, 16115-16149, 1999. 
Logan, J. A., Megretskaia, I. A., Miller, A. J., Tiao, G. C., Choi, D., Zhang, L., Stolarski, R. S., Labow, G. J., Hollandsworth, S. M., Bodeker, G. E., Claude, H., De Muer, D., Kerr, J. B., Tarasick, D. W., Oltmans, S. J., Johnson, B., Schmidlin, F., Staehelin, J., Viatte, P., and Uchino, O.: Trends in the vertical distribution of ozone: A comparison of two analyses of ozonesonde data, J. Geophys. Res., 104, 26373-26399, 1999.

Loveland, T. R., Reed, B. C., Brown, J. F., Ohlen, D. O., Zhu, Z., Yang, L., and Merchant, J. W.: Development of a global land cover characteristics database and IGBP DISCover from $1 \mathrm{~km}$ AVHRR data, Int. J. Remote Sens., 21, 1303-1330, 2000.

Low, P. S., Davies, T. D., Kelly, P. M., and Farmer, G.: Trends in surface ozone at Hohenpeissenberg and Arkona, J. Geophys. Res., 95, 22441-22453, 1990.

MacFarling Meure, C., Etheridge, D., Trudinger, C., Steele, P., Langenfelds, R., van Ommen, T., Smith, A., and Elkins, J.: Law Dome $\mathrm{CO}_{2}, \mathrm{CH}_{4}$ and $\mathrm{N}_{2} \mathrm{O}$ ice core records extended to 2000 years BP, Geophys. Res. Lett., 33, L14810, doi:10.1029/2006g1026152, 2006.

Machida, T., Nakazawa, T., Fujii, Y., Aoki, S., and Watanabe, O.: Increase in the atmospheric nitrous-oxide concentration during the last 250 years, Geophys. Res. Lett., 22, 2921-2924, 1995.

Marenco, A., Gouget, H., Nedelec, P., Pages, J. P., and Karcher, F.: Evidence of a long-term increase in tropospheric ozone from Pic du Midi data series - consequences - positive radiative forcing, J. Geophys. Res., 99, 16617-16632, 1994.

Marlon, J. R., Bartlein, P. J., Carcaillet, C., Gavin, D. G., Harrison, S. P., Higuera, P. E., Joos, F., Power, M. J., and Prentice, I. C.: Climate and human influences on global biomass burning over the past two millennia, Nat. Geosci., 1, 697-702, doi:10.1038/ngeo313, 2008.

McConnell, J. R. and Edwards, R.: Coal burning leaves toxic heavy metal legacy in the Arctic, Proc. Natl. Acad. Sci. USA, 105, 12140-12144, doi:10.1073/pnas.0803564105, 2008.

Metzger, S., Dentener, F., Pandis, S., and Lelieveld, J.: Gas/aerosol partitioning: 1. A computationally efficient model, J. Geophys. Res., 107, 4312, doi:10.1029/2001jd001102, 2002.

Mickley, L. J., Jacob, D. J., and Rind, D.: Uncertainty in preindustrial abundance of tropospheric ozone: Implications for radiative forcing calculations, J. Geophys. Res., 106, 3389-3399, 2001.

Mieville, A., Granier, C., Liousse, C., Guillaume, B., Mouillot, F., Lamarque, J. F., Gregoire, J. M., and Petron, G.: Emissions of gases and particles from biomass burning during the 20th century using satellite data and an historical reconstruction, Atmos. Environ., 44, 1469-1477, doi:10.1016/j.atmosenv.2010.01.011, 2010.

Montzka, S. A., Krol, M., Dlugokencky, E., Hall, B., Jockel, P., and Lelieveld, J.: Small Interannual Variability of Global Atmospheric Hydroxyl, Science, 331, 67-69, doi:10.1126/science.1197640, 2011a.

Montzka, S. A., Reimann, S., Blumenstock, T., Engel, A., Krüger, K., O’Doherty, S., Sturges, W. T., Hendrick, F., Blake, D., Dorf, M., Fraser, P., Froidevaux, L., Jucks, K., Kreher, K., Kurylo, M. J., Mellouki, A., Miller, J., Nielsen, O.-J., Orkin, V. L., Prinn, R. G., Rhew, R., Santee, M. L., Stohl, A., Verdonik, D., Yokouchi, Y., and Yvon-Lewis, S.: Chapter 1: Ozone-Depleting Substances (ODSs) and Related Chemicals, in: WMO/UNEP Scientific Assessments of Ozone Depletion, 2011b.

Mouillot, F., Narasimha, A., Balkanski, Y., Lamarque, J. F., and
Field, C. B.: Global carbon emissions from biomass burning in the 20th century, Geophys. Res. Lett., 33, L01801, doi:10.1029/2005g1024707, 2006.

Myhre, G. and Myhre, A.: Uncertainties in radiative forcing due to surface albedo changes caused by land-use changes, J. Clim., 16, 1511-1524, 2003.

Myhre, G., Highwood, E. J., Shine, K. P., and Stordal, F.: New estimates of radiative forcing due to well mixed greenhouse gases, Geophys. Res. Lett., 25, 2715-2718, 1998.

Myhre, G., Karlsdottir, S., Isaksen, I. S. A., and Stordal, F.: Radiative forcing due to changes in tropospheric ozone in the period 1980 to 1996, J. Geophys. Res., 105, 28935-28942, 2000.

Myhre, G., Myhre, A., and Stordal, F.: Historical evolution of radiative forcing of climate, Atmos. Environ., 35, 2361-2373, 2001.

Myhre, G., Grini, A., and Metzger, S.: Modelling of nitrate and ammonium-containing aerosols in presence of sea salt, Atmos. Chem. Phys., 6, 4809-4821, doi:10.5194/acp-6-4809-2006, 2006.

Myhre, G., Bellouin, N., Berglen, T. F., Berntsen, T. K., Boucher, O., Grini, A., Isaksen, I. S. A., Johnsrud, M., Mishchenko, M. I., Stordal, F., and Tanre, D.: Comparison of the radiative properties and direct radiative effect of aerosols from a global aerosol model and remote sensing data over ocean, Tellus B, 59, 115129, 2007a.

Myhre, G., Nilsen, J. S., Gulstad, L., Shine, K. P., Rognerud, B., and Isaksen, I. S. A.: Radiative forcing due to stratospheric water vapour from CH4 oxidation, Geophys. Res. Lett., 34, L01807, doi:10.1029/2006gl027472, 2007b.

Myhre, G.: Consistency Between Satellite-Derived and Modeled Estimates of the Direct Aerosol Effect, Science, 325, 187-190, doi:10.1126/science.1174461, 2009.

Myhre, G., Berglen, T. F., Johnsrud, M., Hoyle, C. R., Berntsen, T. K., Christopher, S. A., Fahey, D. W., Isaksen, I. S. A., Jones, T. A., Kahn, R. A., Loeb, N., Quinn, P., Remer, L., Schwarz, J. P., and Yttri, K. E.: Modelled radiative forcing of the direct aerosol effect with multi-observation evaluation, Atmos. Chem. Phys., 9, 1365-1392, doi:10.5194/acp-9-1365-2009, 2009.

Nightingale, P. D., Malin, G., Law, C. S., Watson, A. J., Liss, P. S., Liddicoat, M. I., Boutin, J., and Upstill-Goddard, R. C.: In situ evaluation of air-sea gas exchange parameterizations using novel conservative and volatile tracers, Global Biogeochem. Cy., 14, 373-387, 2000.

Ohmura, A.: Observed decadal variations in surface solar radiation and their causes, J. Geophys. Res., 114, D00D05, doi:10.1029/2008jd011290, 2009.

Ohmura, A. and Lang, H.: Secular variation of global radiation over Europe, in: Current Problems in Atmospheric Radiation, edited by: Lenoble, J. and Geleyn, J. F., A. Deepak, Hampton, VA, USA, 98-301, 1989.

Ohmura, A., Gilgen, H., and Wild, M.: Global Energy Balance Archive (GEBA) Report 1: Introduction Zürcher Geographische Schriften, 34, 62 pp., 1989.

Oltmans, S. J., Lefohn, A. S., Harris, J. M., Galbally, I., Scheel, H. E., Bodeker, G., Brunke, E., Claude, H., Tarasick, D., Johnson, B. J., Simmonds, P., Shadwick, D., Anlauf, K., Hayden, K., Schmidlin, F., Fujimoto, T., Akagi, K., Meyer, C., Nichol, S., Davies, J., Redondas, A., and Cuevas, E.: Long-term changes in tropospheric ozone, Atmos. Environ., 40, 3156-3173, doi:10.1016/j.atmosenv.2006.01.029, 2006. 
Parrish, D. D., Dunlea, E. J., Atlas, E. L., Schauffler, S., Donnelly, S., Stroud, V., Goldstein, A. H., Millet, D. B., McKay, M., Jaffe, D. A., Price, H. U., Hess, P. G., Flocke, F., and Roberts, J. M.: Changes in the photochemical environment of the temperate North Pacific troposphere in response to increased Asian emissions, J. Geophys. Res., 109, D23S18, doi:10.1029/2004jd004978, 2004.

Pavelin, E. G., Johnson, C. E., Rughooputh, S., and Toumi, R.: Evaluation of pre-industrial surface ozone measurements made using Schonbein's method, Atmos. Environ., 33, 919-929, 1999.

Penner, J. E., Lister, D. H., Griggs, D. J., Dokken, D. J., and McFarland, M.: Aviation and the global atmosphere, Cambridge Univ. Press, Cambridge, 365 pp., 1999.

Penner, J. E., Chen, Y., Wang, M., and Liu, X.: Possible influence of anthropogenic aerosols on cirrus clouds and anthropogenic forcing, Atmos. Chem. Phys., 9, 879-896, doi:10.5194/acp-9-8792009, 2009.

Pozzoli, L., Janssens-Maenhout, G., Diehl, T., Bey, I., Schultz, M. G., Feichter, J., Vignati, E., and Dentener, F.: Re-analysis of tropospheric sulfate aerosol and ozone for the period 1980-2005 using the aerosol-chemistry-climate model ECHAM5-HAMMOZ, Atmos. Chem. Phys., 11, 9563-9594, doi:10.5194/acp-11-95632011, 2011.

Price, C., and Rind, D.: Possible implications of global climate change on global lightning distributions and frequencies, J. Geophys. Res., 99, 10823-10831, doi:10.1029/94jd00019, 1994.

Price, C., Penner, J., and Prather, M.: $\mathrm{NO}_{\mathrm{x}}$ from lightning 1. Global distribution based on lightning physics, J. Geophys. Res., 102, 5929-5941, doi:10.1029/96jd03504, 1997.

Quaas, J., Boucher, O., and Lohmann, U.: Constraining the total aerosol indirect effect in the LMDZ and ECHAM4 GCMs using MODIS satellite data, Atmos. Chem. Phys., 6, 947-955, doi:10.5194/acp-6-947-2006, 2006.

Rafelski, L. E., Piper, S. C., and Keeling, R. F.: Climate effects on atmospheric carbon dioxide over the last century, Tellus B, 61, 718-731, doi:10.1111/j.1600-0889.2009.00439.x, 2009.

Ramanathan, V. and Carmichael, G.: Global and regional climate changes due to black carbon, Nat. Geosci., 1, 221-227, 2008.

Ramankutty, N. and Foley, J. A.: Estimating historical changes in global land cover: Croplands from 1700 to 1992, Global Biogeochem. Cy., 13, 997-1027, 1999.

Ramaswamy, V., Boucher, O., Haigh, J., Hauglustaine, D., Haywood, J., Myhre, G., Nakajima, T., Shi, G. Y., and Solomon, S.: Radiative Forcing of Climate Change, in: Climatic Change 2001: The scientific basis, edited by: Houghton, J. T., Cambridge Univ. Press, Cambridge, 2001.

Randel, W. J. and Thompson, A. M.: Interannual variability and trends in tropical ozone derived from SAGE II satellite data and SHADOZ ozonesondes, J. Geophys. Res., 116, D07303, doi:10.1029/2010jd015195, 2011.

Rigby, M., Prinn, R. G., Fraser, P. J., Simmonds, P. G., Langenfelds, R. L., Huang, J., Cunnold, D. M., Steele, L. P., Krummel, P. B., Weiss, R. F., O’Doherty, S., Salameh, P. K., Wang, H. J., Harth, C. M., Muhle, J., and Porter, L. W.: Renewed growth of atmospheric methane, Geophys. Res. Lett., 35, L22805, doi:10.1029/2008g1036037, 2008.

Rotstayn, L. D. and Penner, J. E.: Indirect aerosol forcing, quasi forcing, and climate response, J. Clim., 14, 2960-2975, 2001.

Rypdal, K., Rive, N., Berntsen, T. K., Klimont, Z., Mideksa, T.
K., Myhre, G., and Skeie, R. B.: Costs and global impacts of black carbon abatement strategies, Tellus B, 61, 625-641, doi:10.1111/j.1600-0889.2009.00430.x, 2009.

Schulz, M., Textor, C., Kinne, S., Balkanski, Y., Bauer, S., Berntsen, T., Berglen, T., Boucher, O., Dentener, F., Guibert, S., Isaksen, I. S. A., Iversen, T., Koch, D., Kirkevag, A., Liu, X., Montanaro, V., Myhre, G., Penner, J. E., Pitari, G., Reddy, S., Seland, Ø., Stier, P., and Takemura, T.: Radiative forcing by aerosols as derived from the AeroCom present-day and pre-industrial simulations, Atmos. Chem. Phys., 6, 5225-5246, doi:10.5194/acp-6-5225-2006, 2006.

Shindell, D., Faluvegi, G., Lacis, A., Hansen, J., Ruedy, R., and Aguilar, E.: Role of tropospheric ozone increases in 20th-century climate change, J. Geophys. Res., 111, D08302, doi:10.1029/2005jd006348, 2006a.

Shindell, D. T., Faluvegi, G., Stevenson, D. S., Krol, M. C., Emmons, L. K., Lamarque, J. F., Petron, G., Dentener, F. J., Ellingsen, K., Schultz, M. G., Wild, O., Amann, M., Atherton, C. S., Bergmann, D. J., Bey, I., Butler, T., Cofala, J., Collins, W. J., Derwent, R. G., Doherty, R. M., Drevet, J., Eskes, H. J., Fiore, A. M., Gauss, M., Hauglustaine, D. A., Horowitz, L. W., Isaksen, I. S. A., Lawrence, M. G., Montanaro, V., Muller, J. F., Pitari, G., Prather, M. J., Pyle, J. A., Rast, S., Rodriguez, J. M., Sanderson, M. G., Savage, N. H., Strahan, S. E., Sudo, K., Szopa, S., Unger, N., van Noije, T. P. C., and Zeng, G.: Multimodel simulations of carbon monoxide: Comparison with observations and projected near-future changes, J. Geophys. Res., 111, D19306, doi:10.1029/2006JD007100, 2006b.

Skeie, R. B., Berntsen, T., Myhre, G., Pedersen, C. A., Ström, J., Gerland, S., and Ogren, J. A.: Black carbon in the atmosphere and snow, from pre-industrial times until present, Atmos. Chem. Phys., 11, 6809-6836, doi:10.5194/acp-11-6809-2011, 2011.

Smith, S. J., van Aardenne, J., Klimont, Z., Andres, R. J., Volke, A., and Delgado Arias, S.: Anthropogenic sulfur dioxide emissions: 1850-2005, Atmos. Chem. Phys., 11, 1101-1116, doi:10.5194/acp-11-1101-2011, 2011.

Staehelin, J., Thudium, J., Buehler, R., Volzthomas, A., and Graber, W.: Trends in surface ozone concentrations at Arosa (Switzerland), Atmos. Environ., 28, 75-87, 1994.

Stamnes, K., Tsay, S. C., Wiscombe, W., and Jayaweera, K.: Numerically stable algorithm for discrete-ordinate-method radiative-transfer in multiple-scattering and emitting layered media, Appl. Opt., 27, 2502-2509, 1988.

Stevenson, D. S., Dentener, F. J., Schultz, M. G., Ellingsen, K., van Noije, T. P. C., Wild, O., Zeng, G., Amann, M., Atherton, C. S., Bell, N., Bergmann, D. J., Bey, I., Butler, T., Cofala, J., Collins, W. J., Derwent, R. G., Doherty, R. M., Drevet, J., Eskes, H. J., Fiore, A. M., Gauss, M., Hauglustaine, D. A., Horowitz, L. W., Isaksen, I. S. A., Krol, M. C., Lamarque, J. F., Lawrence, M. G., Montanaro, V., Muller, J. F., Pitari, G., Prather, M. J., Pyle, J. A., Rast, S., Rodriguez, J. M., Sanderson, M. G., Savage, N. H., Shindell, D. T., Strahan, S. E., Sudo, K., and Szopa, S.: Multimodel ensemble simulations of present-day and near-future tropospheric ozone, J. Geophys. Res., 111, D08301, doi:10.1029/2005JD006338, 2006.

Storelvmo, T., Hoose, C., and Eriksson, P.: Global modeling of mixed-phase clouds: The albedo and lifetime effects of aerosols, J. Geophys. Res., 116, D05207, doi:10.1029/2010jd014724, 2011. 
Søvde, O. A., Gauss, M., Smyshlyaev, S. P., and Isaksen, I. S. A.: Evaluation of the chemical transport model Oslo CTM2 with focus on arctic winter ozone depletion, J. Geophys. Res., 113, D09304, doi:10.1029/2007jd009240, 2008.

Søvde, O. A., Hoyle, C. R., Myhre, G., and Isaksen, I. S. A.: The $\mathrm{HNO} 3$ forming branch of the $\mathrm{HO} 2+\mathrm{NO}$ reaction: pre-industrialto-present trends in atmospheric species and radiative forcings, Atmos. Chem. Phys., 11, 8929-8943, doi:10.5194/acp-11-89292011, 2011.

Takemura, T., Tsushima, Y., Yokohata, T., Nozawa, T., Nagashima, T., and Nakajima, T.: Time evolutions of various radiative forcings for the past 150 years estimated by a general circulation model, Geophys. Res. Lett., 33, L19705, doi:10.1029/2006g1026666, 2006.

Tanaka, K., Raddatz, T., O'Neill, B. C., and Reick, C. H.: Insufficient forcing uncertainty underestimates the risk of high climate sensitivity, Geophys. Res. Lett., 36, L16709, doi:10.1029/2009g1039642, 2009.

Textor, C., Schulz, M., Guibert, S., Kinne, S., Balkanski, Y., Bauer, S., Berntsen, T., Berglen, T., Boucher, O., Chin, M., Dentener, F., Diehl, T., Easter, R., Feichter, H., Fillmore, D., Ghan, S., Ginoux, P., Gong, S., Kristjansson, J. E., Krol, M., Lauer, A., Lamarque, J. F., Liu, X., Montanaro, V., Myhre, G., Penner, J., Pitari, G., Reddy, S., Seland, O., Stier, P., Takemura, T., and Tie, X.: Analysis and quantification of the diversities of aerosol life cycles within AeroCom, Atmos. Chem. Phys., 6, 1777-1813, doi:10.5194/acp-6-1777-2006, 2006.

Thompson, A. M., Witte, J. C., McPeters, R. D., Oltmans, S. J., Schmidlin, F. J., Logan, J. A., Fujiwara, M., Kirchhoff, V., Posny, F., Coetzee, G. J. R., Hoegger, B., Kawakami, S., Ogawa, T., Johnson, B. J., Vomel, H., and Labow, G.: Southern Hemisphere Additional Ozonesondes (SHADOZ) 1998-2000 tropical ozone climatology - 1. Comparison with Total Ozone Mapping Spectrometer (TOMS) and ground-based measurements, J. Geophys. Res., 108, 8238, doi:10.1029/2001jd000967, 2003a.

Thompson, A. M., Witte, J. C., Oltmans, S. J., Schmidlin, F. J., Logan, J. A., Fujiwara, M., Kirchhoff, V., Posny, F., Coetzee, G. J. R., Hoegger, B., Kawakami, S. J., Ogawa, T., Fortuin, J. P. F., and Kelder, H. M.: Southern Hemisphere Additional Ozonesondes (SHADOZ) 1998-2000 tropical ozone climatology - 2. Tropospheric variability and the zonal wave-one, J. Geophys. Res., 108, 8241, doi:10.1029/2002jd002241, 2003b.

Thomson, A., Calvin, K., Smith, S., Kyle, G., Volke, A., Patel, P., Delgado-Arias, S., Bond-Lamberty, B., Wise, M., Clarke, L., and Edmonds, J.: RCP4.5: a pathway for stabilization of radiative forcing by 2100 , Clim. Change, 109, 77-94, doi:10.1007/s10584-011-0151-4, 2011.
Trenberth, K., Jones, P., Ambenje, P., Bojariu, R., Easterling, D., Tank, A., Parker, D., Rahimzadeh, F., Renwick, J., Rusticucci, M., Soden, B., and Zhai, P.: Observations: Surface and Atmospheric Climate Change, in: Climate Change 2007: The Physical Science Basis. Contribution of Working Group I to the Fourth Assessment Report of the Intergovernmental Panel on Climate, edited by: Solomon, S., Qin, D., Manning, M., Chen, Z., Marquis, M., Averyt, K. B., Tignor, M., and Miller, H. L., Cambridge Univ. Press, New York, USA, 2007.

Trudinger, C. M., Enting, I. G., Rayner, P. J., and Francey, R. J.: Kalman filter analysis of ice core data 2. Double deconvolution of $\mathrm{CO}_{2}$ and $\delta^{13} \mathrm{C}$ measurements, J. Geophys. Res., 107, 4423, doi:10.1029/2001jd001112, 2002.

Tsigaridis, K., Krol, M., Dentener, F. J., Balkanski, Y., Lathiere, J., Metzger, S., Hauglustaine, D. A., and Kanakidou, M.: Change in global aerosol composition since preindustrial times, Atmos. Chem. Phys., 6, 5143-5162, doi:10.5194/acp-6-51432006, 2006.

Turpin, B. J., and Lim, H. J.: Species contributions to PM2.5 mass concentrations: Revisiting common assumptions for estimating organic mass, Aerosol Sci. Tech., 35, 602-610, 2001.

Twomey, S.: Influence of pollution on shortwave albedo of clouds, J. Atmos. Sci., 34, 1149-1152, 1977.

Wang, Y. H. and Jacob, D. J.: Anthropogenic forcing on tropospheric ozone and $\mathrm{OH}$ since preindustrial times, J. Geophys. Res., 103, 31123-31135, 1998.

Wang, Z., Chappellaz, J., Park, K., and Mak, J. E.: Large Variations in Southern Hemisphere Biomass Burning During the Last 650 Years, Science, 330, 1663-1666, doi:10.1126/science.1197257, 2010.

Wild, M.: Global dimming and brightening: A review, J. Geophys. Res., 114, D00d16, doi:10.1029/2008jd011470, 2009.

Wild, M., Gilgen, H., Roesch, A., Ohmura, A., Long, C. N., Dutton, E. G., Forgan, B., Kallis, A., Russak, V., and Tsvetkov, A.: From dimming to brightening: Decadal changes in solar radiation at Earth's surface, Science, 308, 847-850, 2005.

Wild, M., Trüssel, B., Ohmura, A., Long, C. N., König-Langlo, G., Dutton, E. G., and Tsvetkov, A.: Global dimming and brightening: An update beyond 2000, J. Geophys. Res., 114, D00D13, doi:10.1029/2008jd011382, 2009.

Zhou, L., Dickinson, R. E., Tian, Y., Zeng, X., Dai, Y., Yang, Z. L., Schaaf, C. B., Gao, F., Jin, Y., Strahler, A., Myneni, R. B., Yu, H., Wu, W., and Shaikh, M.: Comparison of seasonal and spatial variations of albedos from Moderate-Resolution Imaging Spectroradiometer (MODIS) and Common Land Model, J. Geophys. Res., 108, 4488, doi:10.1029/2002JD003326, 2003. 